\author{
Universidade de São Paulo \\ Escola Superior de Agricultura "Luiz de Queiroz"
}

Impactos econômicos do Novo Código Florestal, no Brasil, 2010 a 2030: uma análise integrada com base nos modelos GLOBIOM-Brasil e TERM-BR

Mari Aparecida dos Santos

Tese apresentada para obtenção do título de Doutora em

Ciências. Área de concentração: Economia Aplicada

Piracicaba

2018 
Mari Aparecida dos Santos

Bacharel em Ciências Econômicas

Impactos econômicos do Novo Código Florestal, no Brasil, 2010 a 2030: uma análise integrada com base nos modelos GLOBIOM-Brasil e TERM-BR

versão revisada de acordo com a resolução CoPGr 6018 de 2011

Orientador:

Prof. Dr. JOAQUIM BENTO DE SOUZA FERREIRA FILHO

Tese apresentada para obtenção do título de Doutora em Ciências. Área de concentração: Economia Aplicada

Piracicaba

2018 


\section{Dados Internacionais de Catalogação na Publicação DIVISÃO DE BIBLIOTECA - DIBD/ESALQ/USP}

Santos, Mari Aparecida dos

Impactos econômicos do Novo Código Florestal, no Brasil, 2010 a 2030: uma análise integrada com base nos modelos GLOBIOM-Brasil e TERM-BR / Mari Aparecida dos Santos. - - versão revisada de acordo com a resolução CoPGr 6018 de 2011. - - Piracicaba, 2018.

$121 \mathrm{p}$.

Tese (Doutorado) - - USP / Escola Superior de Agricultura "Luiz de Queiroz".

1. Novo Código Florestal 2. Impacto econômico 3. GLOBIOM-Brasil 4. TERM-BRL I. Título 
DEDICATÓRIA

DEDICO ESSA TESE AOS MEUS PAIS, QUE SEMPRE APOIARAM E INCENTIVARAM MEU CRESCIMENTO PROFISSIONAL. 


\section{AGRADECIMENTOS}

Agradeço, primeiramente, à Deus que iluminou cada passo desse meu caminho. Em segundo, agradeço aos meus pais, Antonio e llza, que sempre me apoiaram com muito amor e carinho. Agradeço aos meus ex-professores e colegas docentes da PUC-PR, que me apoiaram para esse importante passo da jornada profissional. Quero deixar meus profundos agradecimentos aos que mais me incentivaram, desde o início, para ingressar no doutorado: Dr. Ricardo Kureski; Dra. Rossana Lott Rodrigues; Dr. Antonio Carlos Moretto; e Dr. Jose Ivan de Paula Prohmann.

A seguir agradeço ao meu orientador, Prof. Dr. Joaquim Bento de Souza Ferreira Filho, com o seu apoio e conhecimento técnico, paciência, dedicação e excelente orientação, que me ajudou a construir essa tese, desde a sua idealização até a sua concretização. E agradeço ao Dr. José Eustáquio Ribeiro Vieira Filho, técnico de planejamento e pesquisa do IPEA. Além de serem profissionais que apoiaram tecnicamente, incentivaram e inspiraram essa pesquisa, a qual faz parte do projeto "Agronegócio e Desenvolvimento Econômico Regional no Brasil". Essa experiência partilhada foi fundamental para o desenvolvimento do projeto, a fim de contribuir no âmbito da agropecuária e desenvolvimento econômico.

Passo a agradecer a equipe do Projeto REDD-PAC, em especial ao Dr. Alexandre Xavier Ywata, diretor de estudos e políticas regionais, urbanas e ambientais de carvalho e á assessora Marina G. Pena do IPEA, que partilharam seus dados para compor a base destapesquisa, imprescindível no desenrolar deste trabalho. Quero também agradecer aos demais colaboradores do IPEA e ao apoio financeiro dessa instituição para a realização desta pesquisa.

Agradeço a Escola Superior de Agricultura Luiz de Queiroz - Universidade Estadual de São Paulo (ESALQ-USP), aos professores, em especial aos doutores Humberto Francisco Silva Spolador e Sílvia Helena G. Miranda que contribuíram diretamente nessa pesquisa. Agradeço aos colegas e funcionários do departamento de Economia, Administração e Sociologia, que contribuíram direta ou indiretamente para o aprendizado e capacitação profissional e pessoal. Agradeço a dedicação: da Lu (Biblioteca); da Aline Fermino; da Maielli e da D. Mirian. Assim como, agradeço profundamente a todos os meus colegas de turma, pela amizade e companheirismo, pela presença em momentos distintos e por todo apoio que prestaram durante o período de curso, em especial Alice A. Cruz, Angel S. Fachinelli, Dienice Ana Bini, Geraldo Costa Junior, Gustavo Carvalho Moreira, Leandro Stocco, Mirian Oliveira de Souza e Nataliya D. Popova,. Bem como, agradeço ao Leandro Gilio e ao William Barbosa que me auxiliaram diretamente nessa pesquisa.

Agradeço à todas as moradoras, bem como às irmãs, do Instituto Apostólico Sec de Nossa Senhora do Cenáculo, onde tive a oportunidade de conviver nesse período. Agradeço em especial as grandes amigas que fiz nessa convivência: Ana P. Battel, Angel, Elaine, Judith, Larissa, Micheline, Rócio, Valcides e Valiana.

À todas as pessoas que, direta ou indiretamente, contribuíram para a execução desta tese, ficam meus singelos agradecimentos. 


\section{BIOGRAFIA}

Nascida em 01 de maio de 1984 na região metropolitana de Curitiba no Paraná, na cidade de São José dos Pinhais, filha de llza Pinheiro dos Santos e Antonio Ferreira dos Santos. Iniciou seus estudos ingressando no ensino fundamental da Escola Municipal Ezaltina Camargo Meiga e transferiu-se para a escola Municipal Eugênia Talamini para cursar o segundo ano. Finalizou o ensino fundamental e Médio no Colégio Estadual Chico Mendes. Três anos depois, em 2005 ingressou na Pontifícia Universidade Católica do Paraná (PUC-PR), tendo concluído o bacharelado em Ciências Econômicas em 2009, mesmo ano em que foi aceita para integrar o corpo discente do programa de Mestrado na Universidade Estadual de Londrina. Aos 25 anos iniciou a sua carreira docente na Faculdade Catuaí, em Cambé-PR.

Ao final de 2010 concluíu o Mestrado em Economia Aplicada com a dissertação sobre "Importância econômica do setor educação no Paraná em 2006: uma análise insumo-produto". No próximo ano, de volta à região de Curitiba, lecionou na Faculdade Eseei. Posteriormente, ingressou na Pontifícia Universidade Católica do Paraná, onde incorpora o quadro docente até o momento. Também, trabalhou como pesquisadora no Sesi/Senai em projetos sobre sustentabilidade na indústria e no IPARDES no programa de Apoio a Redes de Pesquisas (PROREDES) pelo IPEA, no Projeto Matriz Insumo-Produto Regional.

Junto ao Fórum Permanente da Agenda 21 Paraná, fez parte do GT de Educação, e foi nomeada integrante do Comitê Paranaense para a Conferência das Nações Unidas sobre Desenvolvimento Sustentável Rio+20. Sua principal linha de pesquisa está inserida no campo da Economia Regional, com estudos sobre matriz insumo-produto, análise de impacto e geração de emprego e renda. Também, desenvolve estudos com foco em desenvolvimento econômico, desenvolvimento sustentável, impactos econômicos. Em 2014, iniciou o doutorado em Economia Aplicada na Escola de Agricultura Luiz de Queiroz-USP. 
EPÍGRAFE

"O problema de sustentabilidade existe e é concreto,

mas não adianta discutir os objetivos sociais e

a sustentabilidade ecológica

sem pensar no terceiro pé do tripé,

que é a viabilidade econômica"

Ignacy Sachs 


\section{SUMÁRIO}

RESUMO

ABSTRACT

LISTA DE FIGURAS

LISTA DE TABELAS

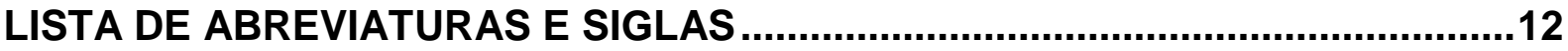

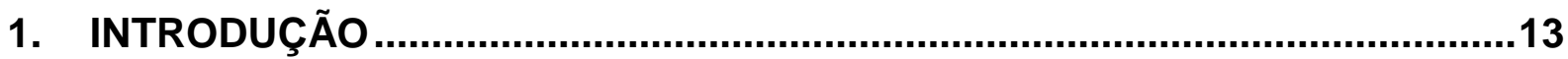

1.1. CONTEXTO, PROBLEMATIZAÇÃO E HIPÓTESE DA PESQUISA …........................13

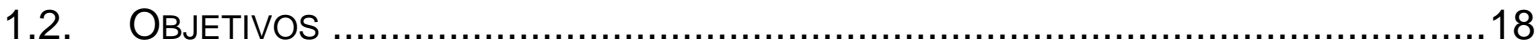

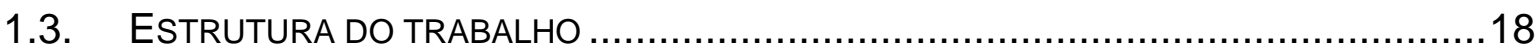

2. REVISÃO DE LITERATURA

2.1. BREVE HISTÓRICO SOBRE A LEGISLAÇÃO AMBIENTAL ...................................19

2.1.1. Novo Código Florestal (Lei 12.651) e suas principais mudanças .............24

2.2. PERSPECTIVAS DE MUDANÇAS COM O NoVo Código FLORESTAL.......................31

2.3. PANORAMA E TENDÊNCIAS DO USO DA TERRA NO BRASIL ..................................37

2.3.1. Projeções do Modelo BLUM e SIMBRASIL (Banco Mundial, 2010) ........51

2.3.2. Projeções do Modelo GLOBIOM-Brasil ...............................................5

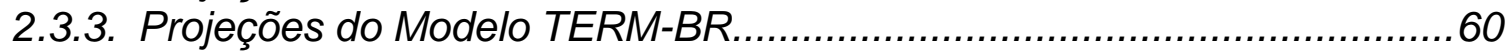

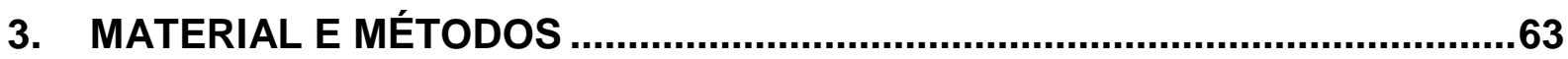

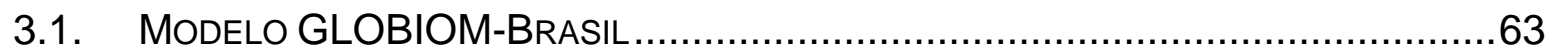

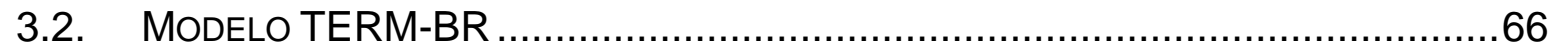

3.2.1. Estrutura de dados do modelo TERM-BR ........................................67

3.3. ESTRATÉGIA DE SIMULAÇÃO E COMPATIBILIZAÇÃO DOS DADOS..........................73

4. RESULTADOS E DISCUSSÃO

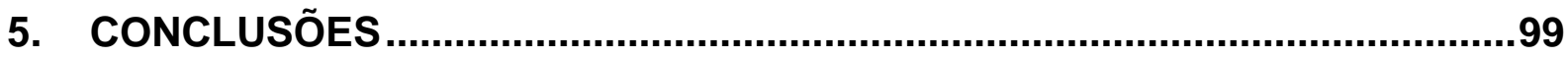

REFERÊNCIAS

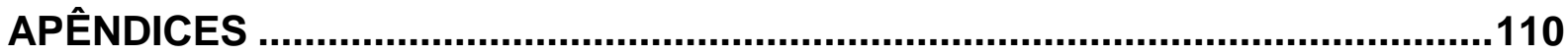


RESUMO

\title{
Impactos econômicos do Novo Código Florestal, no Brasil, 2010 a 2030: uma análise integrada com base nos modelos GLOBIOM-Brasil e TERM-BR
}

\begin{abstract}
O Novo Código Florestal brasileiro se tornou em 25 de maio de 2012 o principal conjunto normativo ambiental instituído pela Lei $n^{\circ} 12.651 / 2012$, que regulamenta a exploração, conservação e recuperação da vegetação nativa em nível nacional. Contudo tal legislação enfrenta Ações Diretas de Inconstitucionalidade (ADIs), as quais apontam prejuízos ambientais por causa da flexibilidade das novas regras relacionadas às áreas de preservação permanente, à redução da reserva legal e também à anistia para àqueles enquadrados por degradação ambiental antes de 22 de julho de 2008. 0 objetivo desta pesquisa foi comparar os impactos econômicos de alterações do Novo Código Florestal, sobre os setores econômicos e regiões do Brasil, considerando três cenários possíveis. Para tanto, foram utilizados dados de cenários específicos gerados pelo modelo GLOBIOM-Brasil: 1) O primeiro cenário traz restrições no uso da terra em caso da utilização parcial do mecanismo de Cotas de Reserva Ambiental (CRA), como forma de compensação do déficit de reserva legal, apenas na agricultura (excluindo pecuaristas); 2) o segundo cenário incorpora restrições no uso no solo em caso da desaprovação do mecanismo Cotas de Reserva Ambiental (CRA), ou seja, desconsidera-se totalmente esse mecanismo de compensação; e 3) no terceiro cenário a restrição do uso da terra está relacionada a desconsideração da anistia das multas e sanções concedida pela Lei 12.651/2012. Esses dados foram integrados à base do Modelo TERM-BR. A metodologia integra dois modelos: GLOBIOM-Brasil e TERM-BR. Os resultados mostraram que o valor dos agregados macroeconômicos, no período acumulado de 2010 a 2030, comparado com a linha de base, houve queda no PIB de $0,12 \%, 0,14 \%$ e $051 \%$, nos cenários 1,2 e 3 , respectivamente. Como também houve queda no Consumo, Gastos do Governo e Importação (vol.) com retração de 0,1\% (cenários 1 e 2) e cerca de 0,5\% (cenário 3), o Investimento se reduz em 0,8\%, 0,8\% e $3,1 \%$, nos respectivos cenários 1,2 e 3 . A queda percentual no salário real é ainda maior do que no consumo, onde houve redução de $0,3 \%$ (cenário 1 e 2) e 1,2\% (cenário 3 ). As exportações aumentam em $0,4 \%$ no primeiro e no segundo cenário, enquanto no terceiro cenário o incremento chega a 1,9\%. A retração no mercado interno, pressiona os setores agroexportadores para comercialização no mercado internacional. No primeiro cenário, a região mais afetada economicamente foi a do Pará-TO com queda de 2,5\% no PIB regional. No segundo cenário o estado do Mato Grosso apresentou maior queda no PIB, em $4,5 \%$. No terceiro cenário, Goiás foi o mais afetado, com queda de $4,3 \%$ no PIB, tais resultados foram ocasionados por perda de área de pastagem e de soja, principalmente. Além disso, os resultados mostram que a soja e a criação de bovinos são as atividades mais impactadas negativamente por tais mudanças na política ambiental.
\end{abstract}

Palavras-chave: Impacto econômico, Novo Código Florestal; GLOBIOM-Brasil; TERMBR 


\section{ABSTRACT \\ Economic Impact of New Forest Code from 2010 to 2030 in Brazil: an integrated analysis based on models GLOBIOM-Brazil and TERM-BR}

New Forest Code of Brazil became the main environmental regulatory on May 25, 2012, established by Law No. 12.651 / 2012, which regulates exploration, conservation and recovery of native vegetation nationwide. However, this legislation faces Direct Unconstitutionality Actions (DUIs), which point to environmental damages because of the flexibility of the new rules related to permanent preservation areas, reduction of legal reserve and amnesty for those framed by environmental degradation before July 22 of 2008 . The objective of this research was to compare the economic impacts of changes in the New Forest Code on economic sectors and regions of Brazil, considering three possible scenarios. For that purpose, we used data from specific scenarios of the GLOBIOM-Brazil model: 1) the first scenario restricts land use in case of partial use of the Mechanism of Environmental Reserves Quotas (CRA in Portuguese) in order to compensate for the legal reserve deficit, only in agriculture (excluding livestock farmers); 2) the second scenario restricts land use in case of disapproval of the Mechanism of Environmental Reserves Quotas mechanism, that is, the mechanism of compensation is totally ignored; and 3) in the third scenario, land use restriction is related to disregarding amnesty of fines and sanctions granted by Law No. 12.651 / 2012. These data were integrated to the base of the TERM-BR model. The methodology integrates two models: GLOBIOM-Brazil and TERM-BR. The results showed that the value of the macroeconomic aggregates, in the accumulated period from 2010 to 2030, compared to the baseline, showed a GDP drop of $0.12 \%, 0.14 \%$ and $051 \%$ in scenarios 1,2 and 3 , respectively. As there was also a decline in consumption, government and importations (vol.), which decreased of $0.1 \%$ (scenarios 1 and 2 ) and around $0.5 \%$ (scenario 3 ), investment decreased by $0.8 \%, 0.8 \%$ and $3.1 \%$ in the respective scenarios 1,2 and 3 . The percentage decrease in real salary higher than in consumption showed a reduction of $0.3 \%$ (scenarios 1 and 2 ) and $1,2 \%$ (scenario 3 ). Exports increased by $0.4 \%$ in scenarios 1 and 2, while in scenario 3 , the increase is close to $1.9 \%$. The downturn in the domestic market pressures the agro-export sectors for commercialization in the international market. In the first scenario, the region most affected economically was Pará-TO, with a drop of $2.5 \%$ in regional GDP. In scenario 2, the state of Mato Grosso showed the greatest GDP drop, at 4.5\%. In scenario 3, Goiás was mostly affected, with a fall of $4.3 \%$ in GDP, such results were caused by loss of grazing area and soybean, mainly. In addition, it was observed that soybean and cattle raising are the activities most negatively impacted by such changes in environmental policy.

Keywords: Economic impact; New Forest Code; GLOBIOM-Brazil;. TERM-BR 


\section{LISTA DE FIGURAS}

Figura 1. Histórico da legislação ambiental brasileira, 1934-2010 .................................20

Figura 2. Esquema do processo de regularização ambiental do Novo Código Florestal......28

Figura 3. Variação geográfica do tamanho do módulo fiscal, Brasil, 2012 …………….........29

Figura 4. Estados, biomas e Amazônia Legal, Brasil, 2017............................................30

Figura 5. Uso da terra, Brasil, 2010 ………………………………………….... 37

Figura 6. Taxas anuais de desmatamento na Amazônia Legal Brasileira, Brasil, 1988-2017*.

Figura 7. Proporção do território nacional alocada em unidades de conservação, por estado,

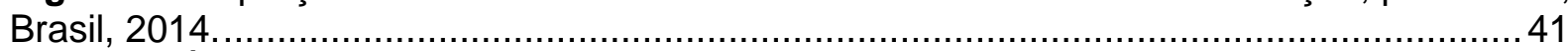

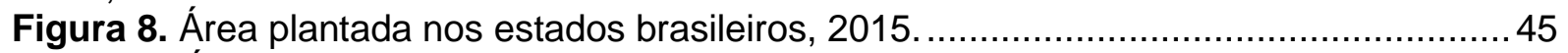

Figura 9. Área da superfície territorial do Brasil, dos estabelecimentos agropecuários e das

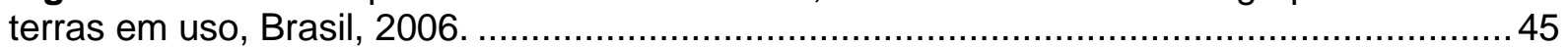

Figura 10. Comparação da área total das terras em uso com lavouras em relação ao total da superfície territorial, por grandes regiões geográficas, em milhões de hectares, Brasil, 2007 e 2013................................................................................................ 46

Figura 11. Proporção das terras em uso com lavouras em relação à superfície territorial do

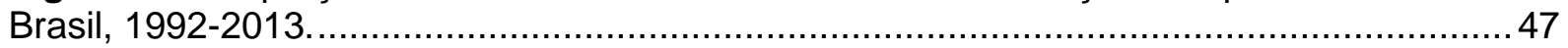

Figura 12. Principais culturas e sua distribuição, no Brasil, 2014 ........................................4 48 Figura 13. Distribuição de imóveis rurais e da área correspondente de titularidade particular e pública por Módulo Fiscal (MF), cadastrados no Sistema Nacional de Cadastro Rural (SNCR), no Brasil, 2014 ......................................................................................

Figura 14. Estrutura do banco de dados do modelo TERM-BR .....................................70

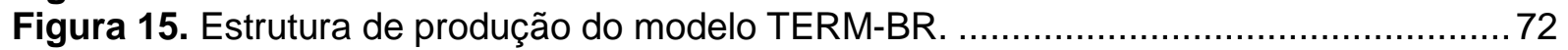

Figura 16. Variação na área de cultivo de soja nos cenários 1,2 e 3, respectivamente,

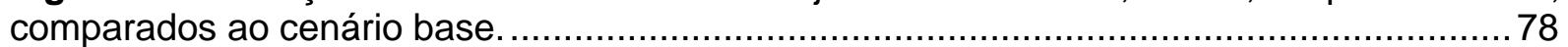

Figura 17. Variação na área da criação de bovinos nos cenários 1, 2 e 3, respectivamente, comparados ao cenário base..............................................................................

Figura 18. Variação na área de cultivo de arroz nos cenários 1, 2 e 3, respectivamente, comparados ao cenário base................................................................................... 79

Figura 19. Projeção da taxa de crescimento anual (\%) do PIB e da população - Brasil

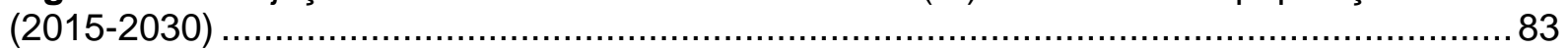

Figura 20. Desvio percentual do PIB real acumulado entre o cenário base em relação aos cenários sem CRA e sem anistia, em 2020 a 2030 ..................................................... 88 Figura 21. Redução percentual da Produção total das indústrias por grande região, cenário 1 (CRA parcial), Brasil, 2010-2030 …………………………………………...... 90

Figura 22. Redução percentual da Produção total das indústrias por grande região, cenário 2 (Sem CRA), Brasil, 2010-2030 ........................................................................... 91

Figura 23. Redução percentual da Produção total das indústrias por grande região, cenário 3 (Sem anistia), Brasil, 2010-2030 ....................................................................... 91

Figura 24. Desvio percentual do PIB real, por UF, nos cenários 1, 2 e 3, relativo ao cenário base, no acumulado período entre 2010-2030 ...........................................................94

Figura 25. Desvio percentual do Consumo real nos cenários 1,2 e 3, relativo ao cenário base, no acumulado período entre 2010-2030 …………………………………..... 95 Figura 26. Desvio percentual do Investimento real nos cenários 1, 2 e 3, relativo ao cenário base, no acumulado período entre 2010-2030 .............................................................96 Figura 27. Desvio percentual do Exportações nos cenários 1, 2 e 3, relativo ao cenário base, no acumulado período entre 2010-2030 .............................................................97 


\section{LISTA DE TABELAS}

Tabela 1. Áreas total desmatadas e remanescentes com respectivo percentual, por bioma, para as Unidades da Federação abrangidas pelo inventário..........................38 Tabela 2. Desflorestamento bruto acumulado, por UF contida na Amazônia Legal, até 2015 40

Tabela 3. Extrato geral do percentual de imóveis rurais cadastrados no CRA, por grande região geográfica, Brasil, 2017 ............................................................ 44 Tabela 4. Classificação da produção de commodities selecionadas, Top 5, entre países, 2016.

Tabela 5. Comparação entre a área total de pastagens e área de vegetação remanescente conversíveis para lavouras/florestas nas regiões do modelo BLUM (em milhões de hectares), Brasil, 2006. .52

Tabela 6. Uso da terra projetado pelo modelo BLUM para principais culturas e pasto (em milhões de hectares) e variação percentual do período, Brasil, 2006, 2008, 2018, 2030

Tabela 7. Uso produtivo da terra (culturas, pasto e florestas) nas diferentes regiões e no Brasil (em milhões de hectares) e variação percentual do período, Brasil, 2006, 2008, 2018, 2030

Tabela 8. Cenário FC, ampla aplicação do Novo Código Florestal, em milhões de hectares, taxa de crescimento anual e variação percentual no período, Brasil, 20102030

Tabela 9. Cenário FCcropCRA, para código florestal sem anistia aos pequenos proprietários, em milhões de hectares, taxa de crescimento anual e variação percentual no período, Brasil, 2010-2030.

.58

Tabela 10. Cenário FCnoCRA, para código florestal sem Cotas de Reserva Ambiental, em milhões de hectares, taxa de crescimento anual e variação percentual no período, Brasil, 2010-2030.

Tabela 11. cenário FCnoSFA, para código florestal sem anistia aos pequenos proprietários, em milhões de hectares, taxa de crescimento anual e variação percentual no período, Brasil, 2010-2030 .........................................................59 Tabela 12. Resultados do modelo, uso da terra e produção, com aumento de produtividade anual necessário para manter a produção 2025 no nível base ...........61 Tabela 13. Mudança na área de cultivo (Mha), por UF, em cenário 1- CRA parcial Brasil (2010-2030) .............................................................................. 80

Tabela 14. Mudança na área de cultivo (Mha), por UF, em cenário 2 - Sem CRA Brasil (2010-2030)

Tabela 15. Desvio percentual da área de cultivo e por UF, dado cenário sem anistia, Brasil, $2010-2030$

Tabela 16. Desvio percentual, entre o cenário base em relação aos cenários 1,2 e 3, das variáveis macroeconômicas selecionadas, no acumulado do período 2010 2030

Tabela 17. Desvio percentual da produção total das indústrias (produtos selecionados), por cenário e por grande região, Brasil, no acumulado do período 2010-2030. 89

Tabela 18. Desvio percentual na demanda por trabalho das indústrias (com maiores quedas), por grande região e por cenário, Brasil, no acumulado do período 20102030. 


\section{LISTA DE ABREVIATURAS E SIGLAS}

\begin{tabular}{|c|c|}
\hline $\begin{array}{l}\text { ADls } \\
\text { APP }\end{array}$ & $\begin{array}{l}\text { Ações Diretas de Inconstitucionalidade } \\
\text { Área de Preservacão Permanente }\end{array}$ \\
\hline BLUM & $\begin{array}{l}\text { Area de Preservação Permanente } \\
\text { Brazil Land Use Model }\end{array}$ \\
\hline BVRio & Bolsa de Valores Ambientais \\
\hline CAR & Cadastro Ambiental Rural \\
\hline CGE & Computable General Equilibrium \\
\hline COP & Convenção das Partes \\
\hline CRA & Cotas de Reserva Ambiental \\
\hline EGC & Equilíbrio Geral Computável \\
\hline FAO & Food and Agriculture Organization of the United Nations \\
\hline FIP-Cerrado & Programa de Investimento Florestal no Bioma Cerrado \\
\hline GEE & Gases de Efeito Estufa \\
\hline GLOBIOM & Global Biosphere Management Model \\
\hline $\mathrm{HRU}$ & Homogeneous Response Units \\
\hline IIASA & International Institute for Applied Systems Analysis \\
\hline INPE & Instituto Nacional de Pesquisas Espaciais \\
\hline IPAM & Instituto de Pesquisa Ambiental da Amazônia \\
\hline LPVN & Lei de Proteção da Vegetação Nativa \\
\hline MATOPIBA & Maranhão, Tocantins, Piauí e Bahia \\
\hline MF & Módulo Fiscal \\
\hline MMA & Ministério do Meio Ambiente \\
\hline MMRF & Monash Multi-Regional Forecasting Model \\
\hline MODIS & Moderate Resolution Imaging Spectroradiometer \\
\hline PGR & Procuradoria Geral da República \\
\hline PIB & Produto Interno Bruto \\
\hline $\begin{array}{l}\text { PPCDAm } \\
\text { Amazônia }\end{array}$ & Plano de Ação para Prevenção e Controle do Desmatamento da \\
\hline $\begin{array}{l}\text { PPCerrado } \\
\text { Queimadas }\end{array}$ & $\begin{array}{l}\text { Plano de Ação para a Prevenção e Controle do Desmatamento e das } \\
\text { no Cerrado }\end{array}$ \\
\hline PRA & Programa de Regularização Ambiental \\
\hline REDD & Reducing Emissions from Deforestation and Forest Degradation \\
\hline REDD-PAC & REDD+ Policy Assessment Center \\
\hline $\mathrm{RL}$ & Reserva Legal \\
\hline SAFs & Sistemas Agroflorestais \\
\hline SICAR & Sistema de Cadastro Ambiental Rural \\
\hline $\begin{array}{l}\text { SIMBRASIL } \\
\text { Brazil }\end{array}$ & Simulate Land Use Changes and Associated Carbon Emissions in \\
\hline SINIMA & Sistema Nacional de Informação sobre Meio Ambiente \\
\hline SISNAMA & Sistema Nacional do Meio Ambiente \\
\hline SNCR & Sistema Nacional de Cadastro Rural \\
\hline SNUC & Sistema Nacional de Conservação da Natureza \\
\hline STF & Supremo Tribunal Federal \\
\hline TERM-BR & The Enormous Regional Model \\
\hline UC & Unidade de Conservação \\
\hline UF & Unidade da Federação \\
\hline VBP & Valor Bruto da Produção \\
\hline ZEE & Zoneamento Ecológico-Econômico \\
\hline
\end{tabular}




\section{INTRODUÇÃO}

O chamado Novo Código Florestal levantouuma série de discussões. Apontaram-se irregularidades e inconstitucionalidades da principal lei nacional sobre a proteção da vegetação nativa em que, ao passar cinco anos, ainda estão sendo discutidas no Supremo Tribunal Federal (STF). Conforme tratam as Ações Diretas de Inconstitucionalidade (ADIs) - ADls nos 4.901, 4.902, 4.903 e 4.937 - que recorrem ao tratamento diferenciado entre proprietários rurais e ao mecanismo de compensação de reserva legal (MACHADO, 2016), drásticas alterações ainda podem ocorrer com relação às restições de uso da terra e, nesse sentido, esse estudo se insere para simular os impactos econômicos de algumas dessas alterações. As próximas subseções deste capítulo contextualizam o tema e apresentam a problemática,a hipótese e o objetivo dessa pesquisa.

\subsection{Contexto, problematização e hipótese da pesquisa}

O Brasil se destaca pela rica biodiversidade e consequente responsabilidade por sua conservação e preservação. Em 2012, um Novo Código Florestal (Lei da Proteção da Vegetação Nativa - LPVN n¹2.651) entrou em vigor no Brasil, objetivando o desenvolvimento sustentável. Assim, exige a preservação e o auxílio à conservação da biodiversidade de um determinado percentual de área da propriedade rural. Embora essa exigência não seja exclusividade desta Lei, foi motivo de questionamentos por ter sido flexibilizada, no ponto de vista ambiental. Determinadas propriedades rurais com déficits ambientais, conforme lei anterior, poderão fazer compensação em outras regiões com o mesmo bioma afetado ao invés do reflorestamento, ou ainda poderão ser anistiadas. Ou seja, criou-se a possibilidade de isenção da obrigatoriedade da reposição florestal àqueles que passarem pelo processo de regularização, confome previsto na Lei 12.651/2012.

Ao longo dos anos, os biomas brasileiros sofreram alterações significativas, devido às ações antrópicas. Grande parte da vegetação nativa encontra-se em áreas particulares. Por isso, há a necessidade de uma lei eficiente em prol do desenvimento sustentável.

O Novo Código Florestal estabelece normas gerais sobre a proteção da vegetação nativa em âmbito nacional, principalmente para Área de Preservação 
Permanente (APP) e Reserva Legal $(R L)$, as quais foram definidas pela própria legislação como:

II - Área de Preservação Permanente - APP: área protegida, coberta ou não por vegetação nativa, com a função ambiental de preservar os recursos hídricos, a paisagem, a estabilidade geológica e a biodiversidade, facilitar o fluxo gênico de fauna e flora, proteger o solo e assegurar o bem-estar das populações humanas;

III - Reserva Legal: área localizada no interior de uma propriedade ou posse rural, delimitada nos termos do art. 12, com a função de assegurar o uso econômico de modo sustentável dos recursos naturais do imóvel rural, auxiliar a conservação e a reabilitação dos processos ecológicos e promover a conservação da biodiversidade, bem como o abrigo e a proteção de fauna silvestre e da flora nativa (BRASIL, 2012, art. $2^{\circ}$ ).

As alterações aprovadas em 2012 sobre a regulamentação de APP e RL, em relação ao código anterior (Lei $n^{\circ} 4.771$, de 15 de setembro de 1965), tem sido alvo de discussões por diversas razões. Retrocessos relacionados à proteção a mbiental são apontados por Araújo e Ganem (2016) e Brancalion et al. (2016), tais como: redução das APPs; permissão de anistia das multas conforme a legislação precedente e; abertura a possibilidade de haver atividades agropecuárias e de infraestrutura em áreas protegidas, com a flexibilidade na recuperação da vegetação. Tais fragilidades da lei ameaçam principalmente os $53 \%$ da vegetação nativa, que está situada no interior das propriedades rurais particulares, no Brasil, conforme Soares Filho et al. (2014).

Com a alteração da legislação em 2012, por meio dos mecanismos instituídos para compensação de áreas desmatadas, tais como Cotas de Reserva Ambiental (CRA) e a desobrigação dos pequenos proprietários de terra ${ }^{1}$ a recompor área desmatada (Anistia), legaliza-se o desmatamento ocorrido até 22 de julho de 2008 - data anterior ao limite conforme decreto sobre crimes ambientais, ํo 6.514/2008 - e eximem os pequenos produtores da necessidade de reflorestamento. Tais regulamentações descaracterizam a função do Código Florestal em relação à proteção do meio ambiente, pois se estima uma redução da necessidade de restauração ambiental em torno de 29 milhões de hectares, como alertam SoaresFilho et al. (2014) e Freitas, Sparovek e Matsumoto (2016).

\footnotetext{
1 Pequenos proprietários, conforme definição da lei 12.651/2012, são àqueles que cujas propriedades e posses rurais se limitam a 4 (quatro) módulos fiscais e que desenvolvem atividades agrossilvipastoris, ou estão em terras indígenas demarcadas, ou ainda demais áreas tituladas de povos e comunidades tradicionais que façam uso coletivo do seu território (Brasil, 2012).
} 
Entretanto, o mercado de CRA permite promover a conservação da floresta a menores custos, enquanto possibilita uma produção agrícola mais eficiente e menos fragmentada. Quanto à anistia das multas e sanções aos pequenos proprietários de terra, enquadrados na Lei de crimes ambientais, os impactos econômicos e sociais sofridos, assim, são amenizados.

Brancalion et al. (2016) consideram que deva haver mudanças pontuais no Novo Código Florestal, principalmente ao que tange o fortalecimento dos órgãos de assistência técnica para a efetiva implementação da legislação ambiental; incentivo aos agentes da cadeia produtiva de restauração e pagamentos por serviços ambientais; restauração da vegetação próxima à área desmatada (mesma microbacia ou bacia hidrográfica) e com semelhante tipo de espécie; e estabelecimento de verificação para identificar a qualidade da restauração ambiental. Além do mais, o Estado precisa atuar no sentido de reparar trechos imprecisos da Lei 12.651, observando o conhecimento científico disponível para tomar suas decisões, com fins de minimização dos prejuízos ambientais e dos impactos ao produtor rural.

Agentes do setor agropecuário, intrinsecamente heterogêneos, que já enfrentam inúmeros desafios para o seu desenvolvimento econômico, conforme apontam os estudos de Vieira Filho e Silveira (2012, 2016), em grande parte relacionados ao meio ambiente, precisam se adequar ao Novo Código Florestal com ou sem apoio técnico e financeiro para o devido cumprimento das exigências legais. Caso não se adequem, estarão sujeitos a desde restrição de crédito agrícola a até sanções administrativas e penais.

A grande maioria das propriedades possuem déficits de APP e $R L$, os quais totalizam-se em aproximadamente 21 milhões de hectares (BRASIL, 2013; SOARES-FILHO ET AL., 2014) sob regime do Novo Código Florestal, considerando anistia aos pequenos proprietários. Isso significa que há necessidade de redução de áreas associadas às atividades produtivas, principalmente na pecuária. Com o pleno funcionamento do Novo Código Florestal (Lei 12.651), o aumento da produção agrícola não poderá depender da expansão fronteiriça (SPAROVEK et al., 2011). Esse, se torna mais um desafio para o proprietário rural.

Além das discussões levantadas na literatura citada nessa pesquisa, o Novo Código Florestal tem passado, desde 2013 até o presente ano de 2018, por processo junto ao Supremo Tribunal Federal (STF) devido às quatro Ações Diretas 
de Inconstitucionalidade (ADIs) cujos pedidos cautelares ainda estão sendo analisados. Três ADls, ajuizadas sob os números 4.901, 4.902 e 4.903, pelo Ministério Público Federal e mais uma quarta, pelo Partido Socialismo e Liberdade (PSOL), sob o número 4.937 (Apêndice A). Entre os pontos mais discutidos estão: a flexibilidade para recompor a reserva legal, que se contrapõe ao direito ambiental adquirido com o Código Florestal de 1965; a anistia das sanções administrativas aos proprietários com áreas consolidadas²; a chamada "escadinha" de APP que diferencia as regras sobre o tamanho mínimo de APP conforme o tamanho do imóvel; entre outros.

Além disso, cada vez mais aumenta a visibilidade sobre as externalidades negativas causadas pelo desmatamento, tais como as relacionadas com a qualidade da terra e alterações climáticas, extremamente prejudiciais para as atividades da agropecuária. Parte da sociedade civil, instituições e organismos do comércio internacional tem se sensibilizado em prol da redução das ações antrópicas no meio ambiente. Ressalte-se que, por meio de apoio popular foi formulado o projeto de lei sobre desmatamento zero, sugestão n`34/2015, mediado pelo Greenpeace, que proíbe a supressão de florestas nativas brasileiras. Nesse sentido, outro projeto de lei tramita, sob o número 77/2015 que dispõe sobre o desmatamento líquido zero na Amazônia e no Cerrado, com uma proposta de compensação do desmatamento legal (AZEVEDO ET AL., 2015) com medidas para enrijecer a legislação ambiental.

Desse modo, aumentam-se os desafios para o setor agropecuário. Conforme Vieira Filho e Fishlow (2017) a agropecuária deslanchou a partir de 1960 e colocou o Brasil entre os maiores exportadores de café, soja, carne bovina e suco de laranja do mundo, o que contribuiu consideravelmente para o superávit na balança comercial, no período entre 1989 e 2013. Embora, a adoção de práticas de agricultura de precisão e melhoria na eficiência no uso dos recursos produtivos tenha sido atrelada ao avanço das fronteiras agrícolas, recentemente isso tem ocorrido no MATOPIBA (região de parte dos estados Maranhão, Tocantins, Piauí e Bahia).

A participação brasileira no mercado de commodities agrícola é de extrema importância para o abastecimento global de alimentos. O país é responsável pela

\footnotetext{
2 Área rural consolidada é definida como " área de imóvel rural com ocupação antrópica preexistente a 22 de julho de 2008, com edificações, benfeitorias ou atividades agrossilvipastoris, admitida, neste último caso, a adoção do regime de pousio" (Brasil, 2012, art. 3ํㅡ, IV).
} 
produção, no âmbito global, de $23 \%$ do açúcar, 13,5\% da carne bovina, 11,3\% de aves, além de $4,7 \%$ do algodão. Como exportador, o Brasil participa no mercado mundial com $38,5 \%$ de açúcar, $21,3 \%$ de óleo de soja, $14,2 \%$ de cane bovina (FAO; 2010, 2013).

Para manter essa posição e atender a crescente demanda futura, o setor agropecuário precisará se adequar em meio às prováveis alterações e imposições das leis ambientais, bem como do comércio internacional, em prol do seu desenvolvimento com redução dos impactos ambientais. A maior conservação e a sustentabilidade no que se refere ao uso dos recursos não renováveis são exigências globais, as quais levam diversos países a firmar acordos e estabelecer metas em prol da redução dos impactos ambientais. Por conseguinte, essas demandas tornam os desafios do setor primário mais complexos em relação ao crescimento econômico e ao uso eficiente dos recursos naturais e produtivos.

A legislação ambiental, cada vez mais, necessita de uma pauta e um embasamento em estudos científicos que quantifiquem os impactos das suas normas. Afinal, a preservação do meio ambiente é fundamental para a garantia de bem-estar das gerações futuras tanto quanto a sustentabilidade socioeconômica. Portanto, tal regulamentação precisa ser eficiente sem que haja prejuízos aos demais âmbitos para um equilíbrio aos pilares do desenvolvimento sustentável: ambiental, econômico e social. Contudo, ainda são escassos os estudos empíricos no âmbito econômico sobre o Novo Código Florestal, entre os quais é possível citar Diniz (2012), Bernasconi (2015), Diniz e Ferreira Filho (2015), além dos estudos que consideram variáveis geofísicas como os de Sparovek et al. (2011), Soares-Filho et al. (2014) e Soterroni et al. (2016).

Do contexto, cabe o questionamento sobre quais os impactos econômicos potenciais do Novo Código Florestal. Regionalmente, como os agentes do setor agropecuário serão afetados a partir da alteração dessa nova lei ( $\left.n^{\circ} 12.651\right)$ ? Que impactos trariam as possíveis mudanças no Novo Código Florestal e quem seriam os mais afetados?

É fato que com a plena implementação do Novo Código Florestal, haverá restrições no uso da terra. Caso os dispositivos da Lei 12.651/2012 se altere em favor de uma maior regeneração ambiental, no caso de desaprovação da anistia e obrigação de compensação das reservas legais na microbacia afetada por um deflorestamento ocasionado anteriormente a julho de 2008 , as restrições no uso da 
terra afetarão diretamente a área produtiva na agropecuária, o que acarreta efeitos de redução no produto interno bruto nacional, bem como nas variáveis econômicas.

\subsection{Objetivos}

Assim, o objetivo principal foi analisar os impactos econômicos potenciais de mudanças no Novo Código Florestal, no Brasil, no período entre 2010 e 2030.

Especificamente, por meio da integração de dois modelos, GLOBIOM-Brasil (modelo de equilíbrio parcial focado em principais setores globais), e TERM-BR (modelo econômico de equilíbrio geral), são analisados os efeitos econômicos regionais dos mecanismos de compensação e de desobrigação de reflorestamento, por meio da simulação de três cenários possíveis, no caso de futuras alterações em prol da maior rigidez do Novo Código Florestal: i) Cotas de Reserva Ambiental (CRA) parcial, com compensação de reserva legal através de cotas somente para agricultores, com excessão dos pecuaristas; ii) Sem Cotas de Reserva Ambiental (CRA), ou seja, desconsidera-se totalmente esse mecanismo de compensação; e iii) se não houvesse anistia aos pequenos proprietários de terra.

\subsection{Estrutura do trabalho}

Esta pesquisa está estruturada em cinco capítulos, sendo o primeiro composto por esta introdução. O segundo apresenta a revisão de literatura sobre o Novo Código Florestal, com enfoque nas suas principais alterações. O terceiro aborda a metodologia utilizada nesta pesquisa. O capítulo quatro apresenta os resultados e discussões. Por fim, no quinto capítulo têm-se as considerações finais. 


\section{REVISÃO DE LITERATURA}

O Novo Código Florestal tem levantado discussões desde o seu projeto, por quase dez anos. Para melhor compreensão sobre tais discussões cabe um breve histórico ressaltando as alterações ocorridas na legislação ambiental. Nesse capítulo, subdividido em três seções, primeiramente ressaltam-se as principais mudanças ocorridas na legislação ambiental ao longo dos anos, com a finalidade de poder comparar com as mudanças ocorridas em 2012 com a aprovação da Lei 12.651, as quais são destacadas na segunda subseção. A terceira subseção aponta as tendências de mudança do uso da terra, no Brasil, numa perspectiva de longo prazo.

\subsection{Breve histórico sobre a legislação ambiental}

Aprovado por Getúlio Vargas, o Decreto que regulamenta o primeiro Código Florestal veio dez anos depois da primeira Carta Magna brasileira, que por sua vez, foi outorgada por D. Pedro I em 25 de março de 1824. As primeiras leis ambientais eram relacionadas ao comércio internacional, na época, com a garantia do monopólio da Coroa Portuguesa sobre a exploração do meio ambiente (SPAROVEK et al., 2011). Nesse período, o meio ambiente era visto como objeto a serviço das necessidades humanas, numa visão antropocêntrica. Sparovek et al. (2011) ressaltam que a relação do homem com o meio ambiente foi sendo questionada com o passar do tempo.

A Figura 1 ilustra a linha do tempo da legislação ambiental de 1934 a 2012. O Código Florestal aprovado em 23 de janeiro de 1934, pelo Decreto 23.793 já trazia a regulamentação para a conservação de: i) "florestas protetoras" conceituadas como àquelas que conservam a qualidade de água e de solo, fixam dunas e áreas de risco como encostas íngremes, servem como defesa fronteiriça, asseguram espécies raras de fauna indígena e salubridade pública, ou formam paisagens; ii) e das "quartas partes", ou seja, 25\% da propriedade privada deveria ser mantida coberta por floresta (BRASIL, 1934). Essas áreas, ainda sem critérios para suas

delimitações, seriam posteriormente denominadas de Área de Preservação Permanente (APP) e Reserva Legal (RL), respectivamente.

Houve necessidade de reformulação do Código de 1934 a partir de três décadas, mais especificamente em 15 de setembro de 1965, com a Lei Federal 
4.771 (hoje denominado antigo Código Florestal), que regulamentava e nominava pela primeira vez a Área de Preservação Permanente (APP) e Reserva Legal (RL) (BRASIL, 1965). Notoriamente, a falta de instrumentos legais para exercer tal legislação dificultou a sua implementação. Benjamin (2012) considerou o Código Florestal de 1965 como revolucionário e, por isso, incompreendido pela sociedade em ascensão econômica.

Como complementariedade da Lei 4.771 surgiram novos instrumentos legais como forma de aperfeiçoamento. Desses, está a lei de $\mathrm{n}^{0} 7.803$ (de 18 de julho de 1989) que revoga as Leis n. 6.535 (de 15 de junho de 1978) e 7.511 (de 7 de julho de 1986) e define novos critérios às áreas de APP e RL, que tiveram largura mínima ampliada e obrigatoriedade de regeneração - este texto deu base ao Art. $4^{\circ}$ do Código aprovado em 2012 (BRASIL, 2012).

\begin{tabular}{|c|c|c|c|c|}
\hline $\begin{array}{l}\text { Código Florestal } \\
\text { de } 1934 \\
\text { Decreto Federal } \\
\text { n. } 23.793 \\
\text { Restrição à destruição } \\
\text { de "florestas } \\
\text { protetoras", mas sem } \\
\text { critérios para delimitaçã } \\
\text { dessas áreas na } \\
\text { propriedade rural. } \\
\text { A área mantida com } \\
\text { floresta não precisava } \\
\text { ser desapropriada } \\
\text { pelo Estado. }\end{array}$ & $\begin{array}{l}\text { Código Florestal } \\
\text { de } 1965 \\
\text { Decreto Federal n. }{ }^{\circ} 7.731 \\
\text { Estabelecimento de } \\
\text { "Áreas de Preservação } \\
\text { Permanente", com } \\
\text { critérios objetivos } \\
\text { para sua delimitação, } \\
\text { e definição de uma } \\
\text { porcentagem máxima } \\
\text { da propriedade } \\
\text { que poderia ser } \\
\text { desmatada, mantida } \\
\text { como Reserva Legal. }\end{array}$ & $\begin{array}{l}\text { Complementações } \\
\text { ao Código Florestal } \\
\text { de } 1965 \\
\text { Lei Federal n. }{ }^{\circ} 7.803 \\
\text { Ampliação das Áreas } \\
\text { de Preservação } \\
\text { Permanente ao longo } \\
\text { dos cursos d'água e } \\
\text { alteração dos critérios } \\
\text { para definir Reservas } \\
\text { Legais, impedindo seu } \\
\text { parcelamento e } \\
\text { obrigando a recuperação } \\
\text { nos casos de déficit. }\end{array}$ & $\begin{array}{l}\text { Complementaçōes } \\
\text { ao Código Florestal } \\
\text { de } 1965 \\
\text { Medida Provisória } \\
\text { n. } 2.166 \\
\text { Ampliação da } \\
\text { porcentagem } \\
\text { mínima de Reserva } \\
\text { Legal na Amazônia } \\
\text { Legal, para } \\
\text { conter o avanço } \\
\text { do desmatamento } \\
\text { na região. }\end{array}$ & $\begin{array}{l}\text { Lei de Proteção } \\
\text { à Vegetação Nativa } \\
{\text { Lei Federal n. }{ }^{\circ} 12.651} \text { Substituição do } \\
\text { Código Florestal de } \\
1965 \text { e complementos, } \\
\text { modificando } \\
\text { alguns dos critérios } \\
\text { para a proteção } \\
\text { da vegetação nativa } \\
\text { e fazendo concessões } \\
\text { aos produtores } \\
\text { rurais para facilitar } \\
\text { a adequação à lei. }\end{array}$ \\
\hline 1934 & 1965 & 1989 & 2001 & 2012 \\
\hline \multicolumn{5}{|l|}{$\bullet \gg \gg \gg \gg \gg \gg \gg 〉$} \\
\hline 1960 & 1980 & 1990 & \multicolumn{2}{|l|}{2000} \\
\hline $\begin{array}{l}\text { Código } \\
\text { das Águas } \\
\text { Decreto n. }{ }^{\circ} 24.643 \text {, } \\
\text { de } 1934 \text {. Dispõe } \\
\text { sobre o acesso, } \\
\text { uso e conservação } \\
\text { dos recursos } \\
\text { hídricos no país }\end{array}$ & $\begin{array}{l}\text { olítica Nacional } \\
\text { e Meio Ambiente } \\
\text { ei Federal n................. } \\
\text { e } 1981 . \text { Compatibiliza } \\
\text { desenvolvimento } \\
\text { conômico e social } \\
\text { om a conservação } \\
\text { o meio ambiente }\end{array}$ & \multicolumn{3}{|l|}{$\begin{array}{l}\text { Constituição Federal } \\
\text { Brasileira de } 1988 \\
\text { Art. } 225 \S 1 .^{\circ} \text {. Garante o } \\
\text { direito ao meio ambiente } \\
\text { equilibrado e incumbe o } \\
\text { Poder Público de zelar pela } \\
\text { proteção e recuperação } \\
\text { dos ecossistemas nativos }\end{array}$} \\
\hline
\end{tabular}

Figura 1. Histórico da legislação ambiental brasileira, 1934-2010.

Fonte: Brancalion et al. (2016).

Com a Constituição Federal Brasileira de 1988, o meio ambiente passou a ser visto como essencial sob à luz da necessidade de defesa e preservação para as presentes e futuras gerações. Em meio às discussões sobre o desenvolvimento sustentável, oportunizadas pela Conferência da Nações Unidas RIO-92, foi aprovada no congresso a Lei 9.605 de crimes ambientais em 1998. Essa legislação torna ações antrópicas danosas ao meio ambiente um crime previsto, que deve ser reparado por meio de sanções administrativas e penais. Assim, aquele que não se 
enquadrasse nos regimes legais até o prazo máximo estipulado poderia arcar com sentença penal condenatória, dentre as quais estão desde advertências e prestação de serviços a até multas e pena privativa de liberdade (BRASIL, 1998).

Além dessa, cabe destacar a Medida Provisória (MPv) $\mathrm{n}^{\circ} 1.511$, de 25 de julho de 1996, que dispõe sobre a proibição do incremento da conversão de áreas florestais em áreas agrícolas na região Norte e na parte Norte da região CentroOeste, medida a qual foi reeditada por diversas vezes até se chegar no texto de outubro de 1997, que estabelece, para a exploração de corte raso, área mínima de $50 \%$ da propriedade em preservação com cobertura arbórea ou $80 \%$ se houvesse em área arbórea a constituição de fitofisionomias florestais, ou seja, flora típica dessa região. Ficariam isentos pequenos proprietários de terra, com área de até 100 hectares, nas quais se exerçam atividades classificadas como de agropecuária familiar. Posteriormente, nova medida $n^{\circ}$ 2.166-67, de 24 de agosto de 2001, transcreve a medida anterior com detalhamento da classificação de pequena propriedade (BRASIL, 2001):

$\S 20$ Para os efeitos deste Código, entende-se por: (Vide Decreto $n^{\circ} 5.975$, de 2006)

I - pequena propriedade rural ou posse rural familiar: aquela explorada mediante o trabalho pessoal do proprietário ou posseiro e de sua família, admitida a ajuda eventual de terceiro e cuja renda bruta seja proveniente, no mínimo, em oitenta por cento, de atividade agroflorestal ou do extrativismo, cuja área não supere:

a) cento e cinquenta hectares se localizada nos Estados do Acre, Pará, Amazonas, Roraima, Rondônia, Amapá e Mato Grosso e nas regiões situadas ao norte do paralelo $130 \mathrm{~S}$, dos Estados de Tocantins e Goiás, e ao oeste do meridiano de $440 \mathrm{~W}$, do Estado do Maranhão ou no Pantanal mato-grossense ou sul-mato-grossense;

b) cinquenta hectares, se localizada no polígono das secas ou a leste do Meridiano de 44 W, do Estado do Maranhão; e

c) trinta hectares, se localizada em qualquer outra região do País (BRASIL, 2001, art. 19).

A MPv 2.166-67 trouxe outra importante alteração que reestabelece a delimitação da reserva legal, de acordo com a região em que se encontra, sendo necessária a preservação de: i) $80 \%$ na propriedade rural situada em área de floresta e $35 \%$ na propriedade rural situada em área de cerrado, em áreas localizadas na Amazônia Legal; sendo no mínimo 20\% na propriedade e 15\% na forma de compensação em outra área, desde que esteja localizada na mesma microbacia, e seja averbada; ii) $20 \%$ na propriedade rural situada em área de floresta, em área de campos gerais ou outras formas de vegetação nativa localizada 
nas demais regiões do País. Essa medida provisória foi revogada e substituída com a aprovação do Novo Código Florestal em 2012 (BRASIL, 2001).

A redução do desmatamento foi observada a partir da aplicação de um conjunto de ações, tais como a criação de áreas protegidas e ampliação de operações de fiscalização ambiental, as quais abrangem a proteção de mosaicos, corredores ecológicos entre outros, que se interligam às Unidades de Conservação (UCs). O Sistema Nacional de Conservação da Natureza (SNUC) protege as UCs, de acordo com Lei no 9.985/2000 (BRASIL, 2000), caracterizadas como: estações ecológicas; reservas biológicas; parques nacionais; monumento natural e; refúgio da vida silvestre. Além dessas unidades, protegidas integralmente, existem as unidades de uso sustentável: área de proteção ambiental; área de relevante interesse ecológico; floresta nacional; reserva extrativista; reserva de fauna; reserva de desenvolvimento sustentável e; reserva particular do patrimônio natural (MINISTÉRIO DO MEIO AMBIENTE, 2016).

Até 2014, o desmatamento na Mata Atlântica se aproximava de 85\% de sua área original. Por sua localização e por abrigar um complexo e diversificado conjunto de formações vegetais, além de recursos hídricos, , tal bioma é habitado por $70 \%$ da população do Brasil.Possuía em 2014, em torno de 15\% da sua área original (IBGE, 2017b). Dados mais recentes estimam o remanescente de Mata Atlântica em torno de 12,5\% entre os anos de 2015 e 2016 (SOSMA, 2015). Embora, conforme IBGE (2018), haja registros de que tal bioma tenha apenas $7 \%$ de sua cobertura original.

A Lei da Mata Atlântica, no 11.428 de 22 de dezembro de 2006 foi aprovada para regulamentar a utilização e proteção da vegetação nativa desse bioma. Segundo Varjabedian (2010), essa região possui uma enorme importância social e ambiental, concorrendo espaço com uma biodiversidade endêmica que necessita de proteção efetiva, que minimize os riscos de sua extinção. Portanto, a legislação ambiental é de extrema necessidade para a conservação da biodiversidade e manutenção dos serviços ambientais. Em 2008, para regulamentar a Lei $n^{\circ}$ 9.605, de 12 de fevereiro de 1998 - a chamada lei de crimes ambientais, foi promulgado o decreto $\mathrm{n}^{\circ} 6.514$ de 22 de julho, que dispõe sobre as infrações e sanções administrativas, tais como multas, apreensões de animais, embargo de obra ou atividade, etc., tendo em vista o considerado infração administrativa ambiental, que relaciona toda ação ou omissão transgressoras das regras jurídicas ambientais. 0 Decreto também regulamenta as leis $n^{\circ} 9.784$, de 29 de janeiro de 1999, $n^{\circ} 8.005$, 
de 22 de março de 1990, $n^{\circ} 9.873$, de 23 de novembro de 1999, e $n^{\circ} 6.938$, de 31 de agosto de 1981 (BRASIL, 2008).

As mais recentes alterações da legislação ambiental ocorreram num contexto econômico favorável para a expansão da agropecuária sobre fronteiras agrícolas. A reação dos agentes envolvidos politicamente, principalmente de representantes dos ambientalistas e concomitantemente dos ruralistas, desencadeou um embate político com pressões para novas alterações na lei, que mais tarde embasariam a criação do projeto de lei de um "Novo Código Florestal". A falta de um consenso se dá pelas visões distintas de lados opostos: enquanto um grupo considera o Novo Código brando demais para conter o desmatamento, outro grupo se depara com regras que significa entraves ao desenvolvimento agrícola (SOARES-FILHO et al., 2014).

Em 25 maio de 2012 o "Novo Código Florestal" foi aprovado, sob a Lei $\mathrm{n}^{\circ}$ 12.651 que determina a conservação das florestas e dos outros ecossistemas naturais, tratando áreas privadas como áreas de interesse social. Com esse instrumento legal, as chamadas APP e RL devem ser preservadas, mas agora com instrumentos e medidas que garantam a efetivação (BRASIL, 2012).

As pressões sobre o Novo Código Florestal provocaram vetos, que culminaram em nova lei: Lei $n^{\circ} 12.727$, de outubro de 2012, que altera a proteção da vegetação, visando o desenvolvimento sustentável sobre APP e RL; a exploração florestal, o suprimento de matéria-prima florestal, o controle da origem dos produtos florestais e o controle e prevenção dos incêndios florestais, e prevê instrumentos econômicos e financeiros para o alcance de seus objetivos.

Contudo, ainda há discussões e questionamentos que remetem à possibilidade de novas alterações. A discussão passa pela pressão e aderência das políticas sobre os agentes heterogêneos envolvidos, relacionados às leis de propriedade da terra e tópicos específicos do Novo Código Florestal, com a pretensão de redução dos gargalos e limitações à expansão da agricultura, que tem sido discutido desde o seu projeto (Projeto de Lei $\left.n^{\circ} 1.876 / 1999\right)$. Outro ponto em discussão é que o Novo Código Florestal trouxe a possibilidade de conversão da multa prevista no art. 50 do Decreto no 6.514 para proprietários de terra que descumpriam o código anterior, até 22 de julho de 2008 - data da publicação do Decreto $n^{\circ} 6.514$, que regulamenta a lei de crimes ambientais (Lei $n^{\circ} 9.605$ ), e trata das infrações ao meio ambiente e das consequentes sanções -, e permite 
compensação de passivos ambientais por meio da compra de Cotas de Reserva Ambiental (CRA) de propriedades com excedentes de vegetação natural. Por outro lado, o mercado de CRA permite desenvolver a conservação da floresta a menores custos enquanto possibilita uma produção agrícola mais eficiente e menos fragmentada.

Além disso, o Novo Código Florestal enfrenta Ações Diretas de Inconstitucionalidade (ADIs), as quais apontam prejuízos ambientais por causa da flexibilidade das novas regras relacionadas às áreas de preservação permanente, à redução da reserva legal e à anistia para àqueles enquadrados por degradação ambiental antes de 22 de julho de 2008.

A próxima subseção traz as principais alterações do Novo Código Florestal que estão em pauta nas discussões da literatura.

\subsubsection{Novo Código Florestal (Lei 12.651) e suas principais mudanças}

O conhecido popularmente como Novo Código Florestal brasileiro, se tornou em 25 de maio de 2012 o principal conjunto normativo ambiental instituído pela Lei de Proteção da Vegetação Nativa (LPVN) n 12.651, que regulamenta a exploração, conservação e recuperação da vegetação nativa em nível nacional (Brasil, 2012).

Três instrumentos foram criados para implementação do novo Código, os quais são, conforme Chiavari e Lopes (2015):

- Cadastro Ambiental Rural - é o registro público eletrônico obrigatório que deve ser realizado, preferencialmente, em órgão municipal ou estadual designado, para a criação de banco de dados integrado no Sistema de Cadastro Ambiental Rural (SICAR), no âmbito do Sistema Nacional de Informação sobre Meio Ambiente (SINIMA), ligado ao Sistema Nacional do Meio Ambiente (SISNAMA). O CAR serve para registrar, por meio de dados georreferenciados ou croquis, as áreas de APP, de uso restrito, de Reserva Legal, de remanescentes de florestas, demais formas de vegetação nativa e das áreas consolidadas especificadas pela Lei 12.651, compondo base de dados para controle e monitoramento. Esse é o principal instrumento para implementação do novo Código, com prazo estipulado até 31 de dezembro de 2017, conforme lei № 13.295, de 14 de junho de 2016. Esse cadastramento é necessário para a concessão de crédito rural e direitos adquiridos com o 
Novo Código Florestal, como as suspensões de multas e uso da APP para compensação da reserva legal, aos proprietários com até quatro módulos fiscais (BRASIL, 2016);

- Cota de Reserva Ambiental (CRA) - é título emitido em nome de uma pessoa determinada, em que representa área com vegetação nativa, existente ou em processo de recuperação, como forma de compensação de $R L$ de mesmo bioma, para imóveis rurais com registros de déficits anteriores a 22 de julho de 2008. Esse título é negociável dentro da Bolsa de Valores Ambientais, para viabilizar o mercado entre os agentes superavitários (com excedente de $R L$ registrada no $C A R$ ) e os deficitários de reserva legal (com área de $R L$ inferior à exigida pelo Novo Código Florestal registrada no CAR). Assim, qualquer proprietário rural com o devido cadastramento no CAR, que possui área de Reserva Legal excedente aos percentuais exigidos, pode fazer o requerimento da emissão da CRA, limitando o uso da terra para preservação, conservação ou recuperação dos recursos ambientais existentes, instituindo servidão ambiental (IPAM, 2015); e

- Programa de Regularização Ambiental (PRA) - é um conjunto de regras com a finalidade de orientar os proprietários e possuidores rurais a regularizar áreas consolidadas em APP e RL (Brasil, 2012, art. 9ํ, Dec. 7.830/12). Após a solicitação de adesão ao PRA, deve ser assinado o Termo de Compromisso, com atividades e cronograma para regularização do imóvel. Bem como, para estabelecer normas gerais e complementares ao PRA, foram criados o Programa Mais Ambiente Brasil e a Política de Integração e Segurança da Informação do SICAR, que define procedimentos para a integração, execução, compatibilização e procedimentos gerais do CAR, por meio de Instrução Normativa.

O produtor rural deficitário de reserva legal tem três formas de regularização, em caso de déficit de RL, desde que seja em mesmo bioma, que podem ser adotadas de forma isolada ou conjunta: i) recompor a Reserva Legal com plantio intercalado de espécies nativas (mínimo de 50\%) com exóticas ou frutíferas (até $50 \%$ ), em sistema agroflorestal ; ii) permitir a regeneração natural da vegetação na área de Reserva Legal; iii) compensar a Reserva Legal no mercado de CRA ou com aquisição, doação ou arrendamento de terras com finalidade de servidão ambiental (BRASIL, 2012). 
O mercado de CRA funcionará numa plataforma em bolsas de mercadorias de âmbito nacional (BVRio) ou sistemas de registro e de liquidação financeira de ativos, de modo que 1 CRA corresponde à 1 hectare de reserva legal. Desse modo, o proprietário deficitário tem maior facilidade e menores custos para regularização junto ao órgão ambiental. Além disso, o ofertante da CRA tem incentivo para manter sua área preservada. Isso contribui para o aumento de estoque carbono, para a biodiversidade, além da manutenção dos serviços ecossistêmicos daquele determinado bioma.

A área das CRAs registradas no SICAR serão monitoradas por satélites, devidamente georreferenciadas e não poderão sobrepor as áreas obrigatórias de reserva legal, com a excessão nas pequenas propriedades rurais, segundo a Lei $n^{\circ}$ 12.651/2012, incluindo assentamentos de reforma agrária, terra indígena titulada e demais áreas tituladas de povos e comunidades tradicionais. Assim, serão averbadas em Cartórios de Registros de Imóveis. Os preços da CRA serão determinados pelo mercado, mas a princípio o valor recebido pelo emitente tenderia a ser, no máximo, correspondente ao valor médio do hectare arrendado no Estado, descontado dos custos de restauração e transação (IPAM, 2015).

Para promoção da regularização do imóvel rural junto ao órgão ambiental competente, distinto em cada estado brasileiro, o proprietário ou possuidor rural terá o prazo máximo de um ano (a ser prorrogável por até mais um ano) para aderir ao PRA e assinar o Termo de compromisso, que especificará prazos e métodos para execução das atividades julgadas necessárias. Essa regularização significa a suspensão ou anistia das sanções administrativas pelos crimes ambientais ocorridos antes de 22 de julho de 2008. Assim, os proprietários de terra que cumprem o PRA não poderão ser autuados por infrações cometidas até tal data (CHIAVARI; LOPES, 2015).

O Novo Código Florestal distingue proprietários de terra e posseiros rurais em dois regimes jurídico ao que tange as obrigações: em âmbito geral (mais restritivo) e especial (mais flexível). O regime geral se aplica a todos os imóveis rurais, enquanto o regime especial se aplica aos imóveis com área rural consolidada. O código também prevê distinção entre os imóveis conforme a sua área. São classificadas como pequenas propriedades aquelas com até 4 (quatro) módulos fiscais, que desenvolvam atividades agrossilvipastoris, bem como as terras indígenas demarcadas e as demais áreas tituladas de povos e comunidades 
tradicionais, que façam uso coletivo do seu território, em que necessita recompor (BRASIL, 2012).

Imóveis com até quatro módulos fiscais deverão cumprir normas e procedimentos conforme regime especial. Imóveis maiores do que quatro módulos ficais deverão cumprir o regime geral. A Figura 2 apresenta um fluxograma detalhado sobre os procedimentos devidos aos proprietários e posseiros rurais para regularização ambiental das propriedades junto aos órgãos competentes. 
Regularizaçáo ambiental de imóvel rural com até quatro módulos fiscais

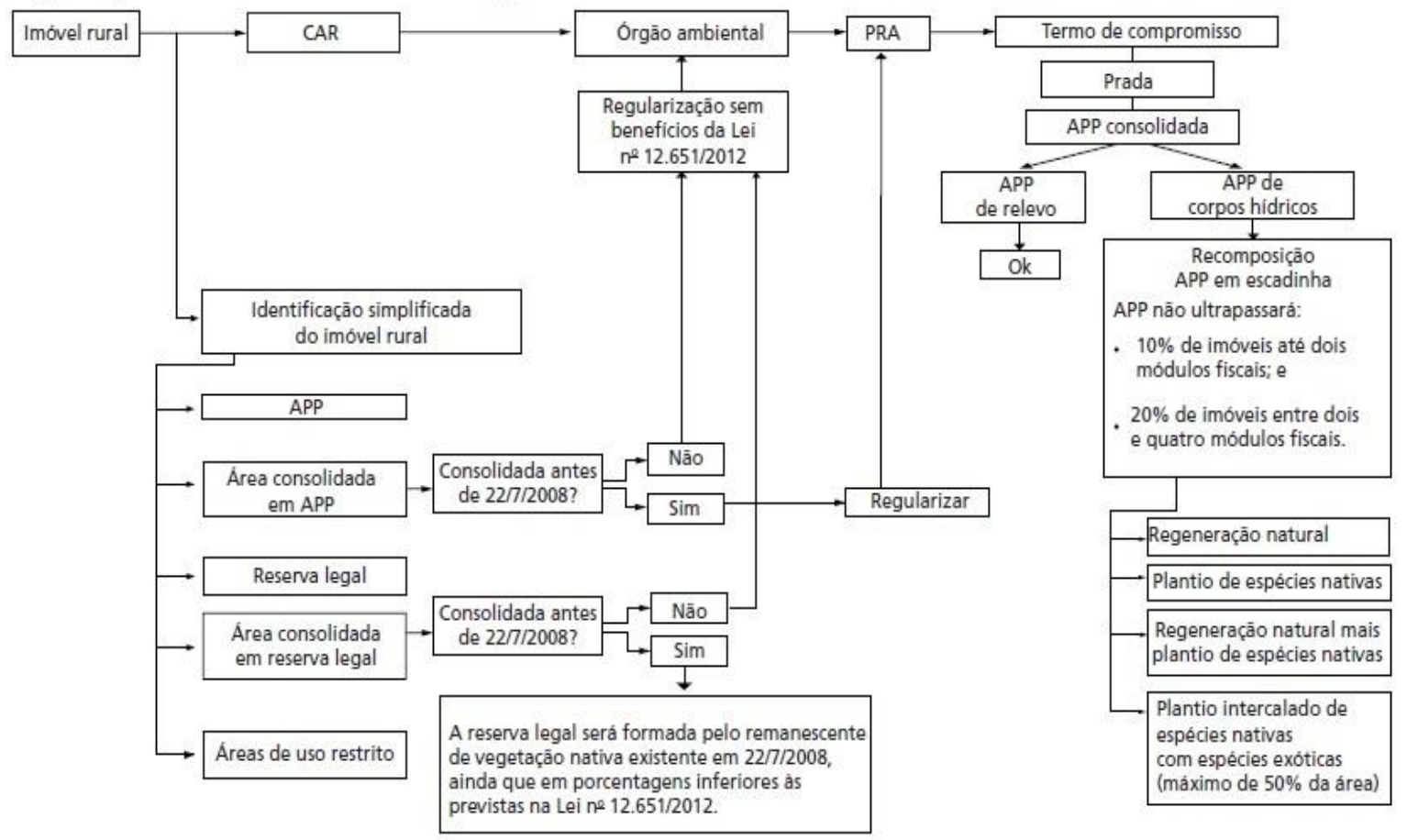

Regularizaçáo ambiental de imóvel rural maior que quatro módulos fiscais

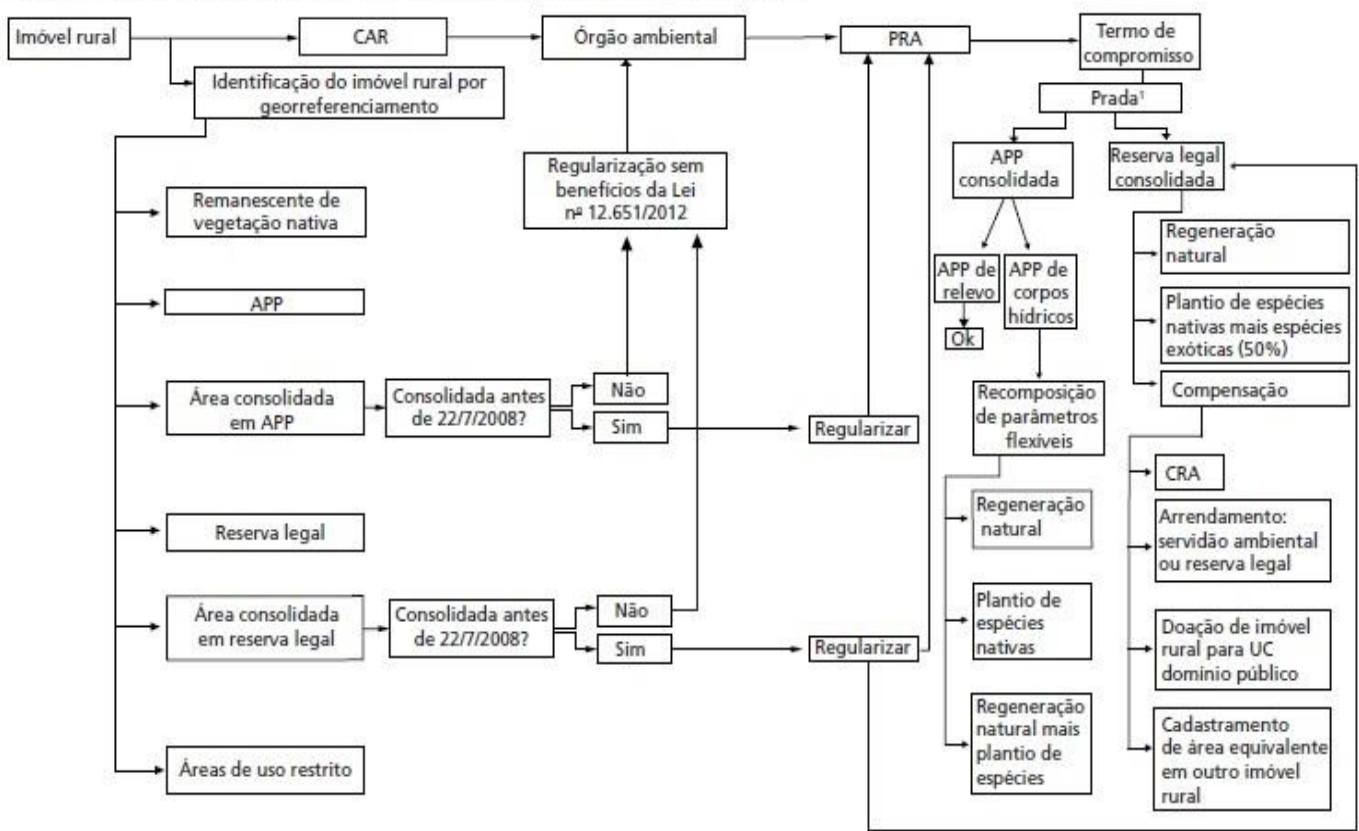

Figura 2. Esquema do processo de regularização ambiental do Novo Código Florestal.

Fonte: adaptado de acordo com Chiavari e Lopes (2015).

O módulo fiscal é uma unidade de medida, em hectares, com tamanho diferente em cada município brasileiro - pode variar entre 5 e 110 hectares conforme ilustra a Figura 3, instituído para fins de cálculo de imposto, conforme a Lei ํㅜ 6.746, de 10 de dezembro de 1979, que considera fatores como o valor da terra nua; a área do imóvel rural; o grau de utilização da terra na exploração agrícola, pecuária e 
florestal; o grau de eficiência obtido nas diferentes explorações; e a área total, no País, do conjunto de imóveis rurais de um mesmo proprietário, para assim tornar economicamente equivalentes as posses em diferentes localizações.

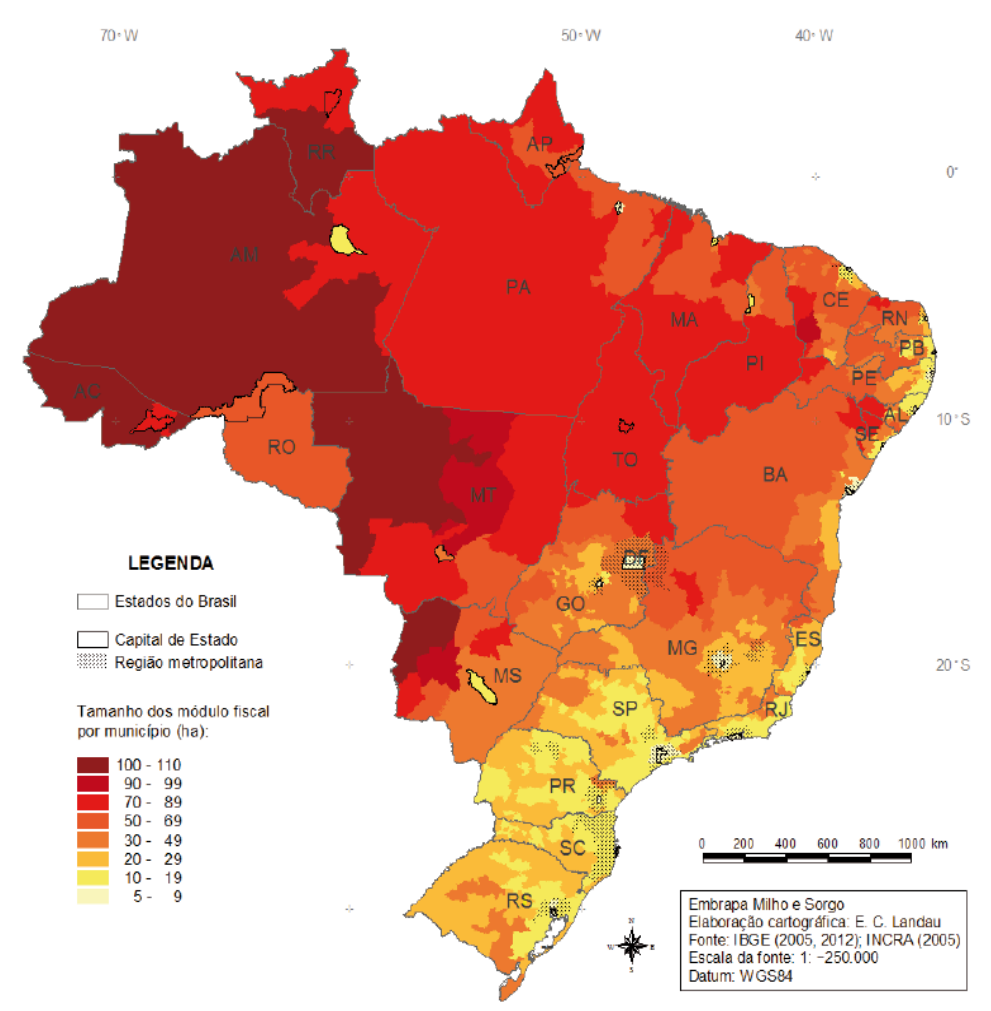

Figura 3. Variação geográfica do tamanho do módulo fiscal, Brasil, 2012.

Fonte: Landau et al. (2012)

Após a finalização do $\mathrm{CAR}^{3}$, serão contabilizados os passivos ou ativos ambientais de acordo com as novas obrigatoriedades da Lei, relacionados à Área de Preservação Permanente (APP), conforme Quadro 1, e Reserva Legal (RL), Figura 4, que ilustra a geografia dos biomas brasileiros e obrigatoriedade de Reserva Legal.

Em relação aos biomas, cabe salientar que os estados Acre, Amapá, Amazonas, Pará e Roraima, $98,8 \%$ de Rondônia, 54\% do Mato Grosso, 34\% do Maranhão e 9\% do Tocantins são ocupados pela Amazônia. A Mata Atlântica ocupa inteiramente Espírito Santo, Rio de Janeiro e Santa Catarina, além de 98\% do Paraná e porções de outras 11 unidades da federação. Já os estados Distrito Federal, $97 \%$ de Goiás, $65 \%$ do Maranhão, $61 \%$ do Mato grosso do Sul, 57\% de Minas Gerais, $91 \%$ de Tocantins e porções de outros seis estados são ocupados pelo Cerrado.

\footnotetext{
${ }^{3}$ Ver Miranda et al. (2017).
} 


\begin{tabular}{|c|c|c|c|c|c|}
\hline \multirow[t]{2}{*}{$\begin{array}{l}\text { Largura do curso } \\
\text { d'água }\end{array}$} & \multirow{2}{*}{$\begin{array}{l}\text { Largura } \\
\text { mínima da } \\
\text { APP em } \\
\text { regime geral }\end{array}$} & \multicolumn{4}{|c|}{$\begin{array}{l}\text { Largura mínima da APP para proprietários de terra em regime } \\
\qquad \text { especial conforme Lei № } 12.727\end{array}$} \\
\hline & & $\begin{array}{c}\text { até } 1 \text { módulo } \\
\text { fiscal }\end{array}$ & $\begin{array}{c}1 \text { até } 2 \text { módulos } \\
\text { fiscais }\end{array}$ & $\begin{array}{c}2 \text { até } 4 \text { módulos } \\
\text { fiscais }\end{array}$ & $\begin{array}{c}\text { acima de } 4 \\
\text { módulos fiscais }\end{array}$ \\
\hline até $10 \mathrm{~m}$ & $30 \mathrm{~m}$ & $5 \mathrm{~m}$ & $8 m$ & $15 \mathrm{~m}$ & 30 a $100 \mathrm{~m}$ \\
\hline 10 a $50 \mathrm{~m}$ & $50 \mathrm{~m}$ & $5 \mathrm{~m}$ & $8 \mathrm{~m}$ & $15 \mathrm{~m}$ & 30 a $100 m$ \\
\hline 50 a $200 \mathrm{~m}$ & $100 \mathrm{~m}$ & $5 \mathrm{~m}$ & $8 \mathrm{~m}$ & $15 \mathrm{~m}$ & 30 a $100 \mathrm{~m}$ \\
\hline 200 a $600 \mathrm{~m}$ & $200 \mathrm{~m}$ & $5 \mathrm{~m}$ & $8 \mathrm{~m}$ & $15 \mathrm{~m}$ & 30 a $100 m$ \\
\hline superior a $600 \mathrm{~m}$ & $500 \mathrm{~m}$ & $5 \mathrm{~m}$ & $8 \mathrm{~m}$ & $15 \mathrm{~m}$ & 30 a $100 \mathrm{~m}$ \\
\hline
\end{tabular}

Obs. * Quanto às áreas no entorno dos lagos e lagoas naturais, em faixa com largura mínima de:

100 metros, em zonas rurais, exceto para o corpo d'água com até 20 hectares de superfície, cuja faixa marginal será de 50 metros; e 30 metros, em zonas urbanas.

As áreas no entorno das nascentes e dos olhos d'água perenes, qualquer que seja sua situação topográfica, deve ter raio mínimo de 50 (cinquenta) metros, de APP.

Quadro 1. Delimitação da largura das Áreas de Preservação Permanente (APP), em zonas rurais ou urbanas, conforme o Novo Código Florestal.

Fonte: Brasil (2012).

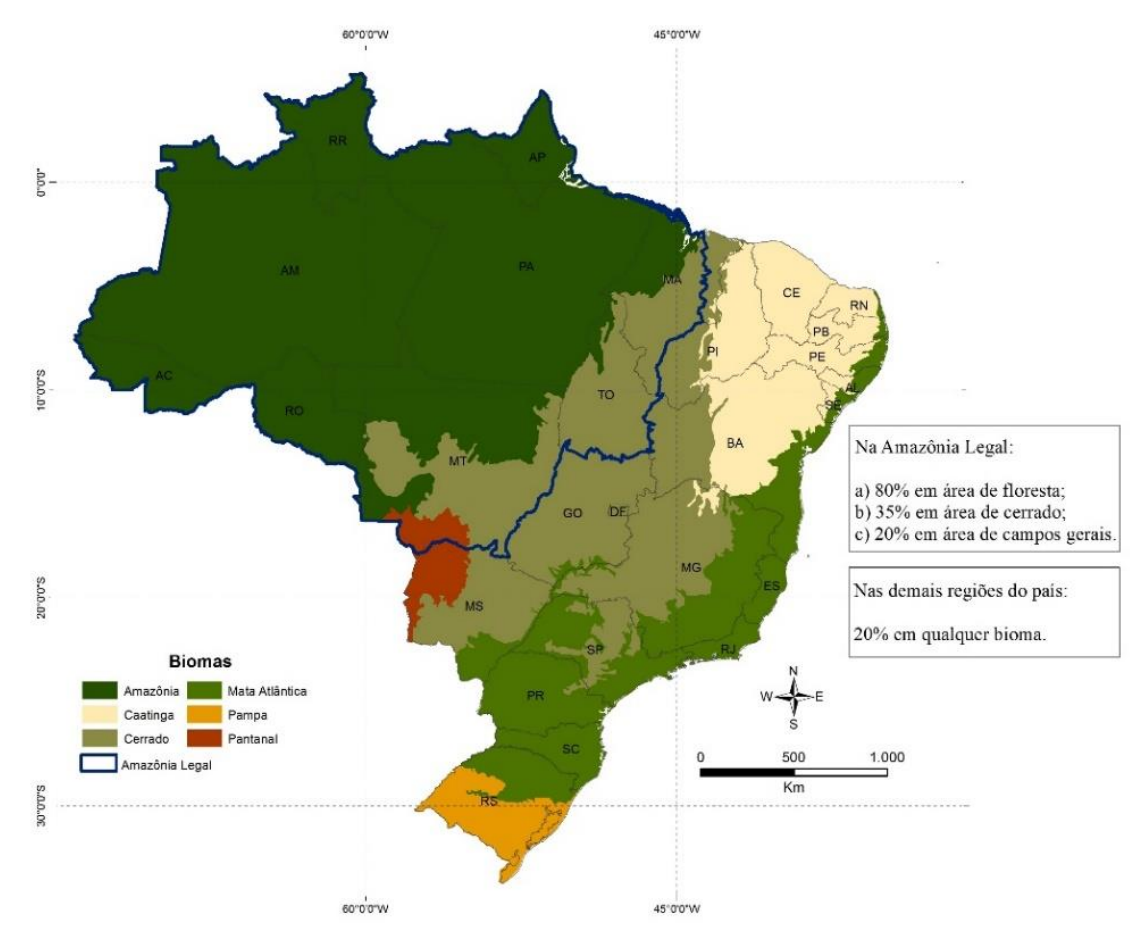

Figura 4. Estados, biomas e Amazônia Legal, Brasil, 2017.

Fonte: Adaptado de REDD-PAC (2016).

A Caatinga cobre os estados do Ceará, $54 \%$ da Bahia, $92 \%$ da Paraíba, $83 \%$ de Pernambuco, $63 \%$ do Piauí, $95 \%$ do Rio Grande do Norte, $48 \%$ de Alagoas e $49 \%$ do Sergipe, além de Minas Gerais em 2\% e Maranhão em 1\%. Dois estados detém o Pantanal: Mato Grosso do Sul em 25\% do e Mato Grosso em 7\%. Enquanto 
$63 \%$ do Rio Grande do Sul é ocupado pelo Pampa (MINISTÉRIO DO MEIO AMBIENTE, 2018).

\subsection{Perspectivas de mudanças com o Novo Código Florestal}

As mudanças acarretadas pela aprovação do Novo Código Florestal significaram certa preocupação, como pode ocorrer em qualquer alteração na legislação com quebra de paradigmas, inovações e com tamanha amplitude que elvolva agentes completamente heterogênios em âmbito nacional. Assim, anos de discussão, desde o início do projeto em 2009 do Novo Código Florestal, não foram suficientes para cessar os questionamentos. Soares Filho et al. (2014) aponta que as críticas se originam pela forma leniente que a Lei 12.651 trata os proprietários de terra, enquanto outros grupos consideram o rigor da legislação ambiental como uma barreira para o desenvolvimento agrícola.

Em estudo de Diniz (2012), em que objetivou comparar os impactos econômicos causado pelos dois últimos códigos florestais(Lei 4.771 e Lei 12.651), são destacadas as principais mudanças promovidas pelo Novo Código Florestal em relação ao anterior: APP que pode ser abatida no cálculo da $R L$ do imóvel, exceto para conversão de novas áreas para uso alternativo da terra; redução da exigência mínima do tamanho da APP em torno de rios para as pequenas propriedades; flexibilização e isenção das multas e sanções para proprietários de terra que descumpriam a Lei até 22 de julho de 2008; compensação da RL em estado diferente da propriedade, condicionado ao mesmo tipo de bioma. O autor resalta as alterações na legislação conforme o Quadro 2, que permite uma sintética comparação.

Sparovek et al. (2011) estimaram déficits de APP em 43 Milhões de hectares (Mha) e RL em 42 Mha, em todas as regiões do Brasil, no antigo regime de Código Florestal. Com as mudanças, em 2012, houve redução dessa exigência, reduzindo o passivo ambiental para 4,5 Mha de APP e em torno de, 13,1 a 16,3Mha de RL (SILVA, MARQUES; SAMBUICHI, 2016).

Com a aplicação do novo regime o déficit em APP e RL fica em 21 Mha, de modo que o passivo se distribui principalmente em: 8 Mha na Amazônia (sendo 1 Mha de APP); 6 Mha na Mata Atlântica (sendo 1,5 Mha de APP); 5 Mha no Cerrado (1,7 Mha de APP). A área total necessária para a recomposição de APP é de 4,8 Mha (SCARAMUZZA ET AL. 2016). 
Freitas, Sparovek e Matsumoto (2016) apontam que em 2015 havia 194 Mha de áreas protegidas com APP e RL. Com as mudanças da legislação ambiental ocorridas em 2012, a necessidade de restauração ambiental foi reduzida de 50 Mha para 21Mha. Além disso, a possibilidade de emissão da CRA na Mata Atlântica e em áreas protegidas nas pequenas propriedades permite a legalização do déficit de reserva legal e não garante a ampliação das áreas protegidas.

\begin{tabular}{|c|c|}
\hline $\begin{array}{l}\text { Código Florestal antigo } \\
\text { (Lei } 4.771 \text { de 1965) }\end{array}$ & $\begin{array}{l}\text { Novo Código Florestal } \\
\text { (Lei } 12.651 \text { de 2012) }\end{array}$ \\
\hline $\begin{array}{l}\text { No cálculo das áreas a serem mantidas como } \\
\text { Reserva Legal eram excluídas aquelas } \\
\text { destinadas às APPs. A sobreposição é permitida } \\
\text { somente em casos particulares, regidos pelo } \\
\text { parágrafo } 6^{\circ} \text { do art. } 16\end{array}$ & $\begin{array}{l}\text { Admite-se que as Áreas de Preservação } \\
\text { Permanente sejam abatidas no cálculo do } \\
\text { percentual da Reserva Legal do imóvel, desde } \\
\text { que isso não implique coonversão de novas } \\
\text { áreas para o uso alternativo da terra. }\end{array}$ \\
\hline $\begin{array}{l}\text { O referencial para cômputo das APPs ripárias era } \\
\text { o nível mais alto dos cursos d'água. }\end{array}$ & $\begin{array}{l}\text { O referencial passa a ser a borda da calha do } \\
\text { leito regular. }\end{array}$ \\
\hline $\begin{array}{l}\text { Estabelece delimitações rígidas para as Áreas de } \\
\text { Preservação Permanente e não permite } \\
\text { flexibilização no caso de regularização. }\end{array}$ & $\begin{array}{l}\text { Mantém parte das delimitações da legislação } \\
\text { atual, mas, para efeito de regularização } \\
\text { ambiental, as APPs nas margens dos cursos } \\
\text { d'água e no entorno de nascentes, olhos d'água, } \\
\text { lagos e lagoas naturais são reduzidas de acordo } \\
\text { com o tamanho da propriedade. }\end{array}$ \\
\hline $\begin{array}{l}\text { Não há imóveis rurais dispensados de cumprir as } \\
\text { exigências da Reserva Legal. }\end{array}$ & $\begin{array}{l}\text { Para os imóveis rurais com até } 4 \text { módulos fiscais, } \\
\text { a Reserva Legal será constituída com a } \\
\text { vegetação natural existente até } 22 \text { de julho de } \\
\text { 2008, mesmo que esta área corresponda a um } \\
\text { percentual inferior àquele determinado em Lei. } \\
\text { Para propriedades maiores, são excluídos os } 4 \\
\text { módulos fiscais da base de cálculo da RL. }\end{array}$ \\
\hline $\begin{array}{l}\text { Para fins de recomposição, permite compensar a } \\
\text { reserva legal por outra área equivalente em } \\
\text { importância ecológica e extenssão, desde que } \\
\text { pertença ao mesmo ecossistema e esteja } \\
\text { localizada na mesma microbacia. }\end{array}$ & $\begin{array}{l}\text { Permite compensar a Reserva Legal inclusive em } \\
\text { outros estados, desde que a área seja } \\
\text { equivalente em extensão à área da Reserva } \\
\text { Legal a ser compensada e esteja localizada no } \\
\text { mesmo bioma. }\end{array}$ \\
\hline
\end{tabular}

Quadro 2. Comparativo de tópicos selecionados entre o Código Florestal de 1965 e o Código Florestal de 2012. Fonte: Diniz (2012).

Conforme Souza (2016), há inconstitucionalidades no âmbito do direito ambiental, principalmente o que tange ao perdão para os que registravam passivos 
ambientais, ou seja, déficit entre a vegetação nativa prevista e a vegetação real existente antes de 22 de julho de 2008 , se sobrepondo à Lei de crimes ambientais, e à permissão de área reduzida de $R L$ e de amplas possibilidades de legalização no Programa de Regularização Ambiental (PRA).

Machado (2016) apresenta os fundamentos legais das Ações Diretas de Inconstitucionalidade aplicadas sobre o Novo Código Florestal. Segundo o autor o embasamento se dá devido às mudanças que ferem os princípios constitucionais do desenvolvimento sustentável e da função social da propriedade, entre os quais podem ser citados: a violação dos princípios da Constituição Federal do retrocesso socioambiental, da igualdade material e da isonomia; a violação do comprometimento da integridade dos atributos que justificam a proteção ao meio ambiente; e a violação do dever geral de não degradação.

Tais mudanças envolvem a legalização do desmatamento ambiental. Conforme Brancalion et al. (2016), a desobrigação da restauração da vegetação nativa aos pequenos proprietários acarreta uma redução de aproximadamente $58 \%$ da área total que seria restaurada, em comparação com os termos da legislação anterior. Segundo o autor, houve avanços importantes com a Lei 12.651, mas as exigências flexibilizadas configuram-se em retrocessos para a proteção e recuperação da vegetação nativa e para a manutenção dos serviços ambientais.

Apesar desses pontos destacados como retrocessos, o Novo Código Florestal traz inovações à respeito da sua aplicação. Os instrumentos criados em 2012, como o Cadastro Ambienta Rural (CAR) condicionado ao crédito rural, as Cotas de Reserva Ambiental (CRA) e o Programa de Regularização Ambiental (PRA), são importantes para efetivação dessa legislação. Soares-Filho et al. (2014) consideram como o mais importante instrumento o mercado de CRA, pois possibilita a criação de um mercado de terras florestais. Assim, haverá incentivos econômicos para manter os ativos ambientais, além de viabilizar a redução de $56 \%$ da dívida de $\mathrm{RL}$.

Diniz e Ferreira Filho (2015) quantificaram em termos de impactos econômicos a flexibilização no âmbito da preservação do meio ambiente. As simulações realizadas mostraram que o impacto do Novo Código Florestal sobre o Produto Interno Bruto (PIB) o reduz em 0,17\%(num cenário mais restrito) e 0,19\% (cenário menos restrito); em regime de antigo Código, em cenário restrito a queda do PIB se aproximaria de 0,37\%. Cabe ressaltar que, esse percentual 
correspondente as alterações de 2012 significa redução de aproximadamente $R \$ 12$ bilhões, com base nas contas nacionais de 2009, não se tratando, segundo o autor, de impacto profundo para a economia brasileira. Os setores mais afetados são, naturalmente, agricultura, pecuária e os demais elos da cadeia do agronegócio.

Conforme apresentado na seção 2.3.3 desta pesquisa, cabe ressaltar que o estudo de Ferreira Filho, Ribera e Horridge (2015), constatou que com a utilização de mecanismos de produção de alimentos, que permitam aumentar a oferta sem expandir a extensão de terra cultivável, é possível evitar o avanço sobre as florestas brasileiras. Assim, o controle do desmatamento não irá comprometer significativamente a capacidade de oferta de produtos agrícolas do Brasil.

Brancalion et al. (2016) apontam como pontos negativos do novo Código Florestal a remoção da proteção de áreas ambientalmente sensíveis; a concessão de isenção de multas relacionadas ao descumprimento da lei anterior; a permissão de manter atividades agropecuárias e infraestrutura em áreas protegidas sem que houvesse a necessidade de recuperar totalmente a vegetação nativa. Assim, tais autores recomendam a utilização do conhecimento científico na tomada de decisão pelo Poder Judiciário para a devida correção de distorções do Novo Código Florestal por estados e municípios.

Em estudo de Reis et al. (2015) que averiguou os impactos econômicos e sociais provocados pela recomposição florestal do município de Bandeirantes - PR, onde $83,63 \%$ dos imóveis rurais são caracterizados como de agricultura familiar, a conclusão aponta a necessidade de mudanças mais justas e economicamente viáveis do ponto de vista local, pois as modificações propostas para o Código Florestal, em trâmite, podem não compensar os danos ambientais provocados, além de afetar negativamente a produção agrícola, mormente a agricultura familiar.

Brancalion et al. (2016) apontam a necessidade de mudanças no Novo Código Florestal, principalmente quanto ao fortalecimento dos órgãos de assistência técnica, relevantes para a efetiva implementação da legislação ambiental: incentivo aos agentes da cadeia produtiva de restauração e pagamentos por serviços ambientais; restauração da vegetação próxima à área desmatada (mesma micro bacia ou bacia hidrográfica) e com semelhante tipo de espécie; e estabelecimento de verificação para identificar a qualidade da restauração ambiental. Além do mais, o Estado precisa atuar no sentido de reparar trechos imprecisos da LPVN, observando 
o conhecimento científico disponível para tomar suas decisões com fins de minimização dos prejuízos ambientais e dos impactos ao produtor rural.

Entretanto as mudanças na legislação ambiental aprovadas pela Lei 12.651/2012 não foram suficientes para satisfazes as inquietações de organismos que por meio da Procuradoria Geral da República (PGR) movem ações legais para sua regulamentação e constitucionalidade. Em suma, as ADls referem-se sobre (Apêndice B):

- ADI n4.901 - recorre sobre a diferenciação dos percentuais mínimos exigidos de Reserva Legal em relação à área do imóvel, nos casos em que o poder público poderá reduzir a $\mathrm{RL}$ para até $50 \%$ da propriedade localizada na Amazônia Legal (que em regra geral é de $80 \%$ ); recorre sobre os parágrafos que eximem, da necessidade de constituição de Reserva Legal, os estabelecimentos de abastecimento público de água e tratamento de esgoto, áreas cedidas para exploração de potencial de energia hidráulica, áreas adquiridas ou desapropriadas com o objetivo de implantação e ampliação de capacidade de rodovias e ferrovias; recorre sobre a permissão do cômputo das APPs no cálculo do percentual da RL do imóvel; recorre sobre a possibilidade de utilizar Cotas de Reserva Ambiental (CRA) no mesmo bioma, independente da região afetada; recorre sobre a possibilidade de regularização do déficit de Reserva Legal registrado até 22 de julho de 2008, independente da adesão ao Programa de Regularização Ambiental (PRA), sob forma de: plantio intercalado de espécies nativas com exóticas ou frutíferas, em sistema agroflorestal; como arrendamento para servidão ou RL; como doação ao poder público de área registrada como Unidade de Conservação (UC) pendente de regularização fundiária; recorre sobre a possibilidade de desmatamento legal, sem necessidade de compensação.

- ADI n4.902 - recorre sobre o artigo que regulamenta supressão não autorizada de vegetação realizada após 22 de julho de 2008; recorre sobre a possibilidade suspensão as sanções decorrentes de infrações cometidas antes de 22 de julho de 2008, no período de implantação do Programa de Regularização Ambiental (PRA); recorre sobre a diferenciação e flexibilização nas exigências aos proprietários com áreas consolidadas; recorre sobre alterações relacionadas à instituição de servidão ambiental.

- ADI n4.903 - recorre sobre as expressões "gestão de resíduos" e "instalações necessárias à realização de competições esportivas estaduais, 
nacionais ou internacionais" relacionadas a definição de utilidade pública; recorre sobre o tratamento dispensado aos imóveis com até quatro módulos fiscais; recorre sobre a dispensa de APP para os reservatórios artificiais; recorre sobre a flexibilização das exigências e tratamento diferenciados para posses com até 15 módulos fiscais para desenvolverem atividades como aquicultura, bem como a infraestrutura física necessária para sua prática; recorre sobre os casos em que será permitida a intervenção ou a supressão de vegetação nativa em APP; recorre sobre as expressões "de 30 (trinta) metros e máxima" e "de 15 (metros) metros e máxima, bem como sobre a exigência mínima para APP no caso de implantação de reservatório d'água destinado a geração de energia ou abastecimento público.

- ADI n4.937 - recorre sobre a definição de utilidade pública; recorre sobre a possibilidade de supressão não autorizada de vegetação realizada após 22 de julho de 2008; recorre sobre a possibilidade de servidão ambiental quando indicado pelo Zoneamento Ecológico-Econômico (ZEE) estadual; recorre sobre a CRA e sobre a possibilidade de compensação em mesmo bioma independente de microbacia; recorre sobre a possibilidade de anuência das infrações cometidas antes de 22 de julho de 2008, durante o período de implantação do PRA; também recorre sobre a diferenciação e flexibilização nas exigências aos proprietários com áreas consolidadas.

Em fevereiro de 2018, foi encerrado o processo de julgamento das ADIs sobre o Novo Código Florestal. Grande parte dos dispositivos das ADIs foram considerados constitucionais, tais como a exclusão das áreas de nascentes intermitentes para composição de APP; a extensão do tratamento dado a pequenas propriedades e a posse rural familiar para imóveis com até quatro módulos fiscais; anistia das multas para proprietários de terras autuados por supressão irregular de vegetação em APP e a suspensão da punibilidade dos crimes previstos pela Lei 9605/1998; a instituição da Cota de Reserva Ambiental (CRA); e a exigência de inscrição no Cadastro Ambiental Rural para recebimento de crédito agrícola; entre outros, apesar das discussões e questionamentos sobre àqueles que interferem diretamente na área de reserva legal e na área de preservação permanente (Brasil, 2012). 


\subsection{Panorama e tendências do uso da terra no Brasil}

O Brasil com um território de aproximadamente 851.576.704,9 hectares possuía em 2012 em torno de 26,26\% de área protegida, enquanto 9,52\% e 23,45\% correspondiam às áreas cultivadas e de pastagens, respectivamente (IBGE, 2016a). Os biomas brasileiros sofreram perdas significativas com o avanço da agricultura e ampliação das áreas de pastagens.

A Figura 5 ilustra a configuração do uso da terra em 2010, com destaque para as ações antrópicas agrícolas.

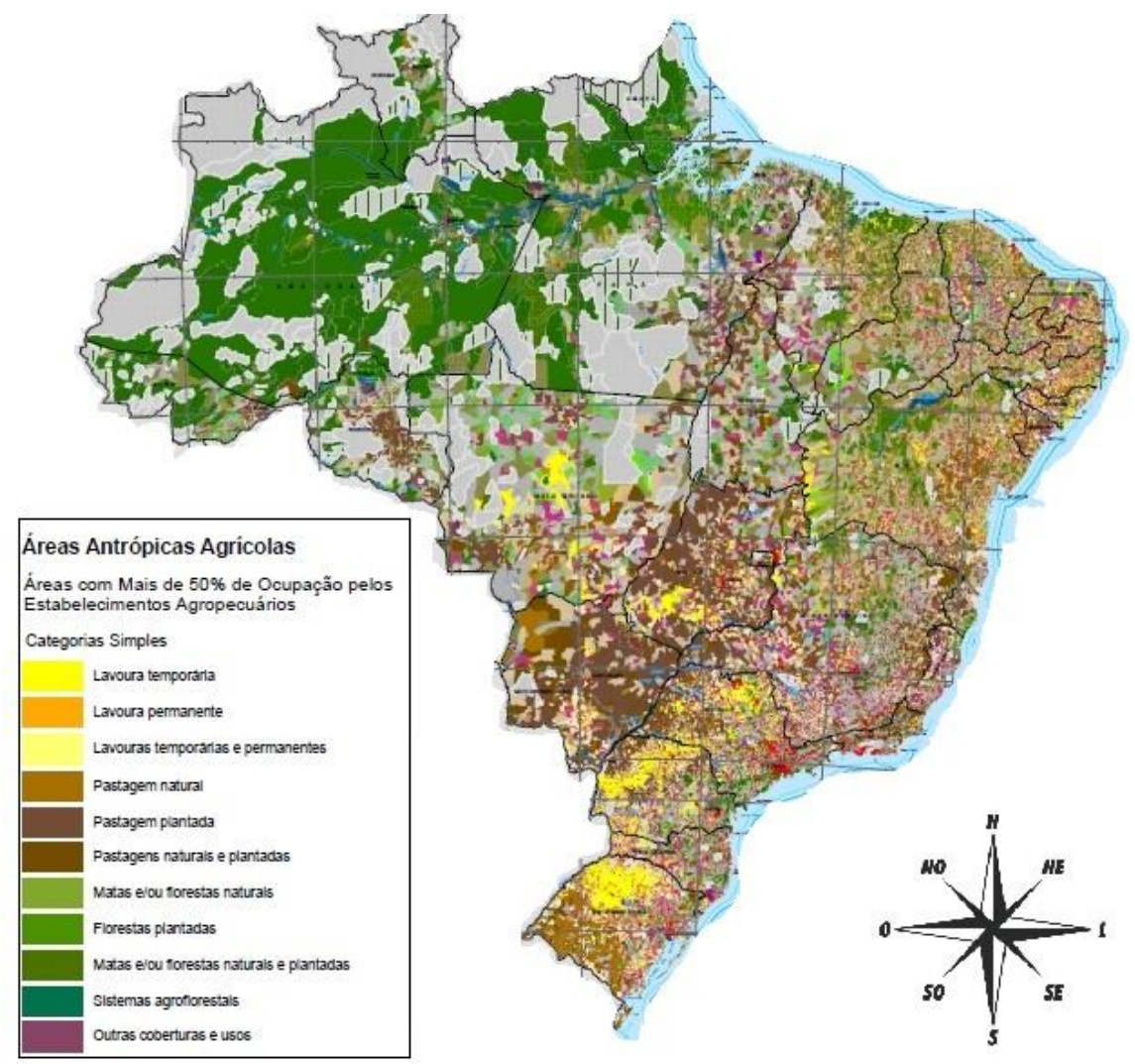

Figura 5. Uso da terra, Brasil, 2010

Fonte: IBGE (2017a).

A Tabela 1 apresenta com maior detalhamento as áreas desmatadas $\mathrm{e}$ remanescentes por bioma e UF (IBGE, 2017b). 
Tabela 1. Áreas total desmatadas e remanescentes com respectivo percentual, por bioma, para as Unidades da Federação abrangidas pelo inventário.

\begin{tabular}{|c|c|c|c|c|}
\hline Bioma /Ano & UF & $\begin{array}{c}\text { Área } \\
\text { desmatada } \\
\left(\mathrm{km}^{2}\right)\end{array}$ & $\begin{array}{c}\text { Área } \\
\text { remanescente } \\
\left(\mathrm{km}^{2}\right)\end{array}$ & $\begin{array}{c}\% \\
\text { Remanescente }\end{array}$ \\
\hline \multirow{18}{*}{$\begin{array}{l}\text { Mata Atlântica } \\
\text { até } 2014\end{array}$} & Alagoas & 13.703 & 1.539 & $10,1 \%$ \\
\hline & Bahia & 154.926 & 24.843 & $13,8 \%$ \\
\hline & Ceará & 7.223 & 1.430 & $16,5 \%$ \\
\hline & Espírito Santo & 40.464 & 5.607 & $12,2 \%$ \\
\hline & Goiás & 11.567 & 331 & $2,8 \%$ \\
\hline & Mato Grosso do Sul & 54.093 & 9.687 & $15,2 \%$ \\
\hline & Minas Gerais & 243.950 & 32.284 & $11,7 \%$ \\
\hline & Paraíba & 5.313 & 667 & $11,2 \%$ \\
\hline & Paraná & 170.954 & 25.439 & $13,0 \%$ \\
\hline & Pernambuco & 14.758 & 2.126 & $12,6 \%$ \\
\hline & Piauí & 17.187 & 9.433 & $35,4 \%$ \\
\hline & Rio de Janeiro & 34.561 & 9.154 & $20,9 \%$ \\
\hline & Rio Grande do Norte & 3.076 & 432 & $12,3 \%$ \\
\hline & Rio Grande do Sul & 120.547 & 17.823 & $12,9 \%$ \\
\hline & Santa Catarina & 67.348 & 28.370 & $29,6 \%$ \\
\hline & São Paulo & 144.091 & 26.622 & $15,6 \%$ \\
\hline & Sergipe & 9.215 & 975 & $9,6 \%$ \\
\hline & Total & 1.112 .975 & 196.761 & $15,0 \%$ \\
\hline \multirow{13}{*}{ Cerrado até 2010} & Bahia & 56.880 & 94.468 & $62,4 \%$ \\
\hline & Distrito Federal & 4.104 & 1.698 & $29,3 \%$ \\
\hline & Goiás & 215.845 & 113.750 & $34,5 \%$ \\
\hline & Maranhão & 52.392 & 159.700 & $75,3 \%$ \\
\hline & Mato Grosso & 155.310 & 203.527 & $56,7 \%$ \\
\hline & Mato Grosso do Sul & 164.448 & 51.567 & $23,9 \%$ \\
\hline & Minas Gerais & 190.731 & 142.979 & $42,8 \%$ \\
\hline & Paraná & 2.621 & 1.121 & $30,0 \%$ \\
\hline & Piauí & 15.789 & 77.635 & $83,1 \%$ \\
\hline & Rondônia & 14 & 438 & $96,9 \%$ \\
\hline & São Paulo & 73.196 & 7.941 & $9,8 \%$ \\
\hline & Tocantins & 69.019 & 183.780 & $72,7 \%$ \\
\hline & Total & 1.000 .348 & 1.038 .605 & $50,9 \%$ \\
\hline \multirow{11}{*}{ Caatinga até 2009} & Alagoas & 10.767 & 2.269 & $17,4 \%$ \\
\hline & Bahia & 160.457 & 140.470 & $46,7 \%$ \\
\hline & Ceará & 59.558 & 87.832 & $59,6 \%$ \\
\hline & Maranhão & 1.154 & 2.600 & $69,3 \%$ \\
\hline & Minas Gerais & 5.822 & 5.277 & $47,5 \%$ \\
\hline & Paraíba & 23.781 & 27.481 & $53,6 \%$ \\
\hline & Pernambuco & 44.714 & 36.673 & $45,1 \%$ \\
\hline & Piauí & 48.722 & 109.037 & $69,1 \%$ \\
\hline & Rio Grande do Norte & 23.325 & 26.389 & $53,1 \%$ \\
\hline & Sergipe & 6.910 & 3.173 & $31,5 \%$ \\
\hline & Total & 385.210 & 441.201 & $53,4 \%$ \\
\hline \multirow{2}{*}{ Pampa até 2009} & Rio Grande do Sul & 96.289 & 63.719 & $39,8 \%$ \\
\hline & Total & 96.289 & 63.719 & $39,8 \%$ \\
\hline \multirow{3}{*}{ Pantanal até 2009} & Mato Grosso & 11.406 & 49.225 & $81,2 \%$ \\
\hline & Mato Grosso do Sul & 11.753 & 78.073 & $86,9 \%$ \\
\hline & Total & 23.159 & 127.298 & $84,6 \%$ \\
\hline
\end{tabular}

Fonte: IBGE (2017b) 
A configuração do uso da terra no Brasil destaca a forte atuação antrópica no território brasileiro, conforme os registros do IBGE (2017b). Entre 1970 e 2007, foram convertidas aproximadamente $420.000 \mathrm{~km}^{2}$ das áreas cobertas de floresta. Com isso, outros problemas no âmbito ambiental se agravam afetando inclusive as atividades do setor agropecuário. O bioma mais afetado foi a Mata Atlântica, em 2014 havia apenas 15\% de vegetação remanescente, ainda fragmentada em toda sua extensão, que abriga fluxo de mananciais hídricos e uma grande biodiversidade endêmica além de promover proteção da terra entre outros serviços ambientais. Os remanecentes registrados dos demais biomas ficavam em torno de $50,9 \%$ do Cerrado Brasileiro em 2010; 53,4 \% da Caatinga, 39,8\% do Pampa e $84,6 \%$ do Pantanal, em 2009.

Enquanto, na região da Amazônia Legal o desflorestamento bruto total foi estimado em $776.671 \mathrm{Km} 2$, até 2015. O remanescente sofreu perda na média de $8.119 \mathrm{Km}^{2} /$ ano, no período entre 2006 e 2016.

A Figura 6 ilustra a taxa anual de desmatamento na Amazônia Legal Brasileira. Embora, ainda exista pressão para supressão da vegetação sobre a região fronteiriça, o desmatamento foi reduzido de forma expressiva a partir de 2004, quando a taxa registrava 27.772. $\mathrm{Km}^{2} /$ ano, passando para $7.893 \mathrm{Km}^{2} /$ ano em 2016 . As regiões mais pressionadas, nesse sentido, foram as do estado do Pará, Mato Grosso, e Rondônia, nesta ordem.

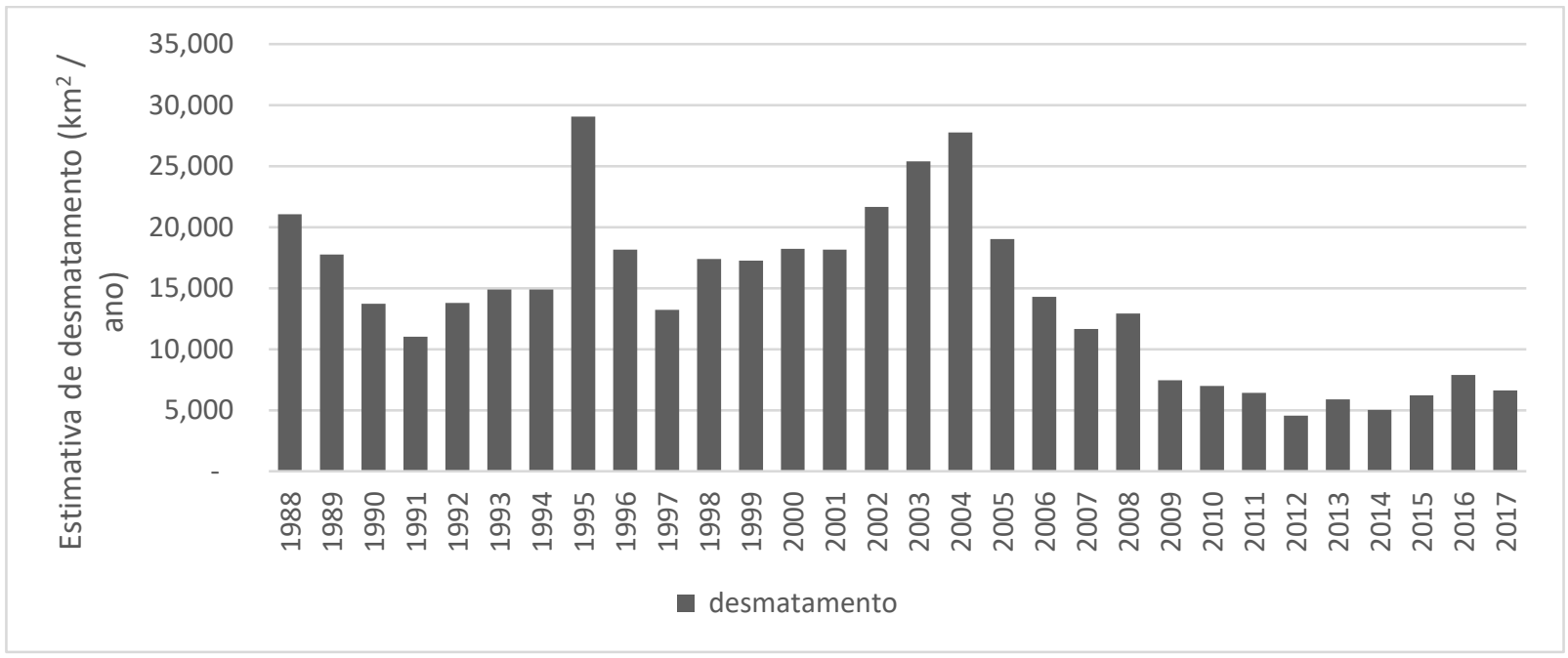

Figura 6. Taxas anuais de desmatamento na Amazônia Legal Brasileira, Brasil, 1988-2017*.

Fonte: INPE (2017).

* última atualização: 17/10/2017. 
Entretanto, o governo brasileiro assumiu compromissos para aumentar a proteção e restauração dos biomas, com a finalidade de redução do desmatamento, proteção dos recursos hídricos e mitigação do Gases de Efeito Estufa (GEE), em acordos internacionais, tais como realizado na Conferência das Partes da Convenção de Mudanças do Clima de Paris (COP 21), bem como na Declaração Conjunta Brasil-Estados Unidos sobre Mudanças do Clima (MACHADO, 2016).

Além disso, importantes oportunidades de cooperação se figuram em três planos de ações do governo: Plano de Ação para Prevenção e Controle do Desmatamento da Amazônia (PPCDAm); do Marco de Varsóvia para REDD $+{ }^{4}$ e do Fundo Amazônia.

As taxas de desmatamento na Amazônia Legal no período entre 2005 e 2013 atingiram quedas recordes, registrando em 2012 a menor do período (IBGE, 2017b). Além do mais, o desflorestamento acumulado desse bioma representa $15 \%$ da extensão territorial da região. A Tabela 2 detalha a áreas de desflorestamento da Amazônia Legal, ocorrido até 2015, em cada estado.

Tabela 2. Desflorestamento bruto acumulado, por UF contida na Amazônia Legal, até 2015

\begin{tabular}{l|l|r}
\hline Bioma /Ano & UF & $\begin{array}{r}\text { Desflorestamento bruto } \\
\text { acumulado }\left(\mathrm{km}^{2}\right)\end{array}$ \\
\hline & Acre & 21.928 \\
& Amapá & 2.368 \\
& Amazonas & 41.373 \\
& Maranhão & 112.864 \\
Amazônia Legal 2015 & Mato Grosso & 208.457 \\
& Pará & 266.724 \\
& Rondônia & 84.535 \\
& Roraima & 9.888 \\
& Tocantins & 28.564 \\
\hline Total & & 776.671
\end{tabular}

Fonte: IBGE (2017b).

\footnotetext{
${ }_{4}$ REDD+:Redução das Emissões por Desmatamento e Degradação florestal é um conjunto de incentivos econômicos desenvolvido no âmbito da Convenção-Quadro das Nações Unidas sobre Mudança do Clima (UNFCCC) para recompensar financeiramente países em desenvolvimento por seus resultados de Redução de GEEs, além de incluir a conservação florestal, manejo florestal sustentável e aumento dos estoques de carbono em áreas de floresta.
} 
A redução do desmatamento é reflexo de programas do governo, que proporcionam ações de monitoramento, fiscalização e controle, além da criação de áreas protegidas, as quais abrangem mosaicos, corredores ecológicos entre outros, que se interligam às Unidades de Conservação (UCs). O Sistema Nacional de Conservação da Natureza (SNUC) protege as UCs, de acordo com Lei no 9.985/2000, caracterizadas como: estações ecológicas; reservas biológicas; parques nacionais; monumento natural e; refúgio da vida silvestre. Além dessas unidades, protegidas integralmente, existem as unidades de uso sustentável, as quais são: área de proteção ambiental; área de relevante interesse ecológico; floresta nacional; reserva extrativista; reserva de fauna; reserva de desenvolvimento sustentável e; reserva particular do patrimônio natural (MINISTÉRIO DO MEIO AMBIENTE, 2016).

Em 2014, 17,20\% do país correspondiam a áreas de conservação, cerca de 1,46 milhões de $\mathrm{km}^{2}$. Dessas áreas, 1 milhão de $\mathrm{km}^{2}$ estão concentradas em cinco estados: Amazonas (AM), Pará (PA), Amapá (AP), Maranhão (MA) e Bahia (BA), onde predominam os biomas Amazônia, Cerrado e Caatinga. No estado do Amapá, a proporção da área das unidades de conservação chega a cobrir $62,80 \%$ do seu território. No Pará essa área chega a 32,20\%, no Amazonas 26,30\%, no Maranhão e Bahia tal cobertura é cerca de 19,20\% e 10,40\%, respectivamente (IBGE, 2015).

A Figura 7 ilustra a proporção percentual das áreas de conservação em relação à área territorial brasileira, distribuída por unidade da federação.

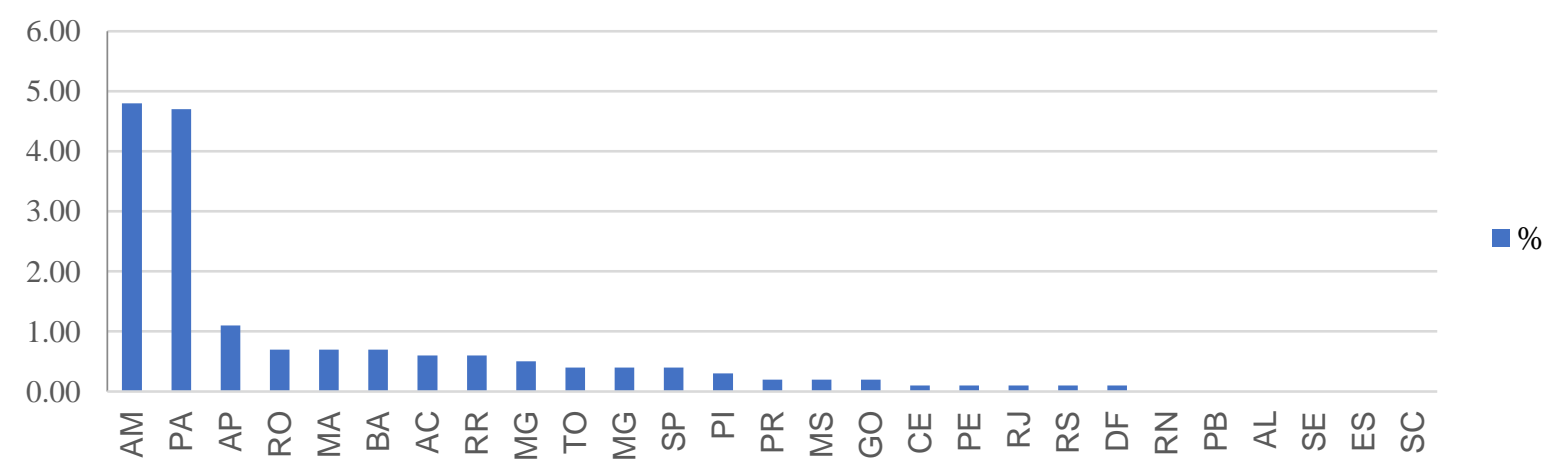

Figura 7. Proporção do território nacional alocada em unidades de conservação, por estado, Brasil, 2014.

Fonte: adaptado de IBGE (2017b).

Na 21 $1^{\text {a }}$ Conferência do Clima (COP 21), ocorrida em Paris em 2015, houve consenso entre os países para redução de emissões dos gases de efeito estufa, a fim de minimizar o aquecimento global, limitado ao aumento de $1,5^{\circ} \mathrm{C}$ até 2100 . Os resultados desse mais recente consenso priorizam energias renováveis, agricultura 
de baixo carbono e restauração florestal, no Brasil. Além disso, o acordo prevê um apoio financeiro, com piso de US\$ 100 bilhões por ano, aos países em desenvolvimento, tendo em conta as suas necessidades e prioridades. O documento também ressalta o papel importante do setor agropecuário quanto a salvaguarda alimentar em contrapartida das vulnerabilidades particulares dos sistemas de produção aos impactos adversos da mudança climática.

A preocupação com o meio ambiente é crescente, como também é cada vez maior a apreensão com a segurança alimentar. Tais assuntos permeiam as discussões sobre o desenvolvimento do setor agropecuário, que é cada vez mais pressionado para aumento da produtividade com baixo impacto ambiental.

A área da pecuária tem decrescido no Brasil com a expansão das áreas de lavouras, nas últimas décadas. Á medida em que se busca melhorar a produtividade das pastagens, se reduz a pressão sobre as fronteiras agrícolas. Programas do governo, como o Plano Setorial de Mitigação e de Adaptação às Mudanças Climáticas para a Consolidação de uma economia de Baixo Carbono (Plano ABC), que oferecem recursos especificamente para recuperação das pastagens impulsionam a melhoria da produtividade e eficiência quanto ao uso dos recursos naturais no campo. Além disto, com um aumento de demanda por terras, haveria consequentemente aumento dos custos de produção para o setor primário, acarretando necessidade de maior eficiência desse setor.

O Plano $A B C$ de forma direta e indireta contribui para a redução do desmatamento nos biomas Amazônia e Cerrado, por isso exige uma agricultura inovadora com práticas sustentáveis, tais como integração lavoura-pecuária-floresta, bem como suas derivações, Sistemas Agro Florestais (SAFs), plantio direto, recuperação de pastagens degradadas, recursos para aumento da fixação de nitrogênio nas lavouras, entre outras práticas relacionadas à produção de baixo carbono, concomitante à redução do desflorestamento. (ASSAD et al., 2013).

O Cadastro Ambiental Rural (CAR) facilitará a integração de informações que poderão ser utilizadas para benefício da implementação do Plano $A B C$, para que se atinja o seu objetivo, com foco naqueles municípios que já possuem atividades agropecuárias consolidadas, no entanto necessitam de políticas públicas para incrementar a sua sustentabilidade. Além dessa integração, o Plano ABC possui uma grande sinergia com demais programas em prol do meio ambiente, tais como: Plano de Ação para a Prevenção e o Controle do Desmatamento na 
Amazônia Legal (PPCDAm); Plano de Ação para a Prevenção e Controle do Desmatamento e das Queimadas no Cerrado (PPCerrado); Plano de Investimento do Brasil para o Programa de Investimento Florestal no Bioma Cerrado (FIPCerrado), do Banco Mundial (ASSAD et al.; 2013).

A heterogeneidade socioeconômica dos proprietários e posseiros rurais dificulta a implementação de programas, bem como leis, no âmbito nacional. Isso é ainda mais visível na região Norte e Nordeste do país, onde se encontram em maior número de agricultores de baixa renda ou extrema pobreza, com maiores dificuldades para adoção de novas tecnologias de produção agropecuária. $O$ agravante é a amplitude na diferenciação de renda entre os dois extremos. 85\% valor bruto da produção (VBP) agropecuária foi gerada por apenas $10 \%$ dos estabelecimentos (de média e alta renda), enquanto $90 \%$ dos estabelecimentos (de baixa renda e pobreza extrema) é capaz de produzir apenas 15\% do VBP (VIEIRA FILHO; FISHLOW, 2017).

Por isso, as dificuldades para os pequenos proprietários frente às novas exigências ambientais começam pelo cadastramento no CAR. Os custos com a elaboração dos documentos são altos para uma grande maioria de proprietários e posseiros rurais. A efetividade do novo Código dependerá diretamente do devido funcionamento dos instrumentos de apoio criados para a concretização da legislação ambiental vigente. As unidades de apoio, assistência técnica e extensão rural existentes não conseguem atender em sua totalidade os imóveis rurais que necessitam. Até 31 de julho de 2016, havia aproximadamente 3,7 milhões de imóveis rurais cadastrados no Sistema de Cadastro Ambiental Rural (SICAR), correspondentes a uma área de 408,9 Mha, incluindo as unidades de conservação (SERVIÇO FLORESTAL BRASILEIRO, 2016). Após um ano da prorrogação do prazo, esse número aumentou para aproximadamente 4,2 milhões de imóveis, em uma área de 444,5 Mha, superando os $100 \%$ da área passível de cadastro (Tabela 3). As estimativas dos órgãos ambientais se baseiam em dados do Censo Agropecuário de 2006, isso justifica a inconsistência nas informações sobre os imóveis rurais existentes, visto que nas regiões Norte, Sudeste e Sul a área cadastrada supera a área passível de cadastro. Entretanto, os estados da região Nordeste e Centro-oeste ainda possuem número significativo de imóveis não cadastrados, conforme as estimativas. O prazo para cadastramento tem sido 
prorrogado desde maio de 2015, e ainda há possibilidade de prorrogação, em casos especiais, após 2017.

Tabela 3. Extrato geral do percentual de imóveis rurais cadastrados no CRA, por grande região geográfica, Brasil, 2017

\begin{tabular}{|c|c|c|c|c|c|}
\hline Região & & $\begin{array}{c}\text { Área } \\
\text { Passível de } \\
\text { Cadastro }^{1} \\
\text { em hectares }\end{array}$ & $\begin{array}{c}\text { Área } \\
\text { Cadastrada } \\
\text { (em } \\
\text { hectares) } \\
\end{array}$ & $\begin{array}{c}\text { Imóveis } \\
\text { Cadastrados } \\
\text { (unidade) }\end{array}$ & $\begin{array}{l}\text { Percentual de } \\
\text { Área } \\
\text { Cadastrada }^{2}\end{array}$ \\
\hline \multirow[t]{5}{*}{ Geral Brasil } & Norte & 93.717 .515 & 132.509 .276 & 628.658 & Acima de $100 \%$ \\
\hline & Nordeste & 76.074 .156 & 61.009 .757 & 1.185 .536 & $80,20 \%$ \\
\hline & Centro-Oeste & 129.889 .570 & 122.606 .157 & 387.496 & $94,39 \%$ \\
\hline & Sudes & 56.374 .996 & 62.144 .631 & 1.068 .416 & Acima de $100 \%$ \\
\hline & & 397.836 .864 & 418.749 .003 & 4.474 .133 & Acima de $100 \%$ \\
\hline Subtotal ${ }^{3}$ & & 397.836 .864 & 411.001 .629 & 4.275 .970 & Acima de $100 \%$ \\
\hline Unidades de $\mathrm{C}$ & & & 25.705 .075 & 18.958 & \\
\hline Total $^{4}$ & & 423.541 .940 & 444.454 .078 & 4.493 .091 & Acima de $100 \%$ \\
\hline
\end{tabular}

Fonte: Serviço Florestal Brasileiro (2017)

1'Área estimada com base no Censo Agropecuário 2006 (IBGE) e nas atualizações do Distrito Federal e dos estados Amapá, Amazonas, Espírito Santo, Pará e Mato Grosso.

2 Percentual calculado com base na área passível de cadastro.

${ }^{3}$ As informações correspondem à soma dos dados: do Sistema de Cadastro Ambiental Rural - SICAR (em 31/10/2017); dos sistemas estaduais do Espírito Santo (31/10/2017), Mato Grosso do Sul (em 31/10/2017) e São Paulo (em 29/10/2017); considera o número de beneficiários dos Assentamentos da Reforma AgráriaUnidades.

${ }^{4}$ As informações incluem os dados cadastrados no SICAR referentes às Unidades de Conservação da Natureza de Uso Sustentável nas quais admite-se a permanência de populações tradicionais.

A Figura 8 destaca os estados com maior área de utilização agrícola. 


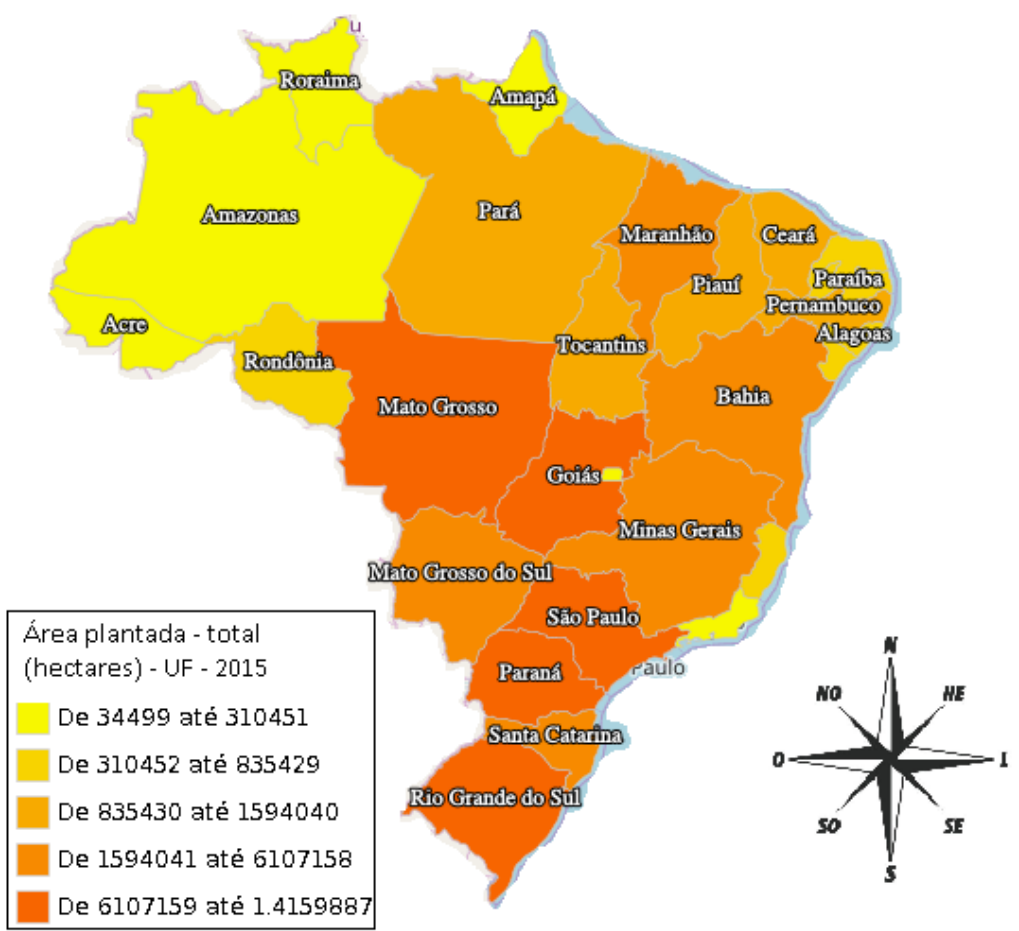

Figura 8. Área plantada nos estados brasileiros, 2015.

Fonte: IBGE (2016c).

Nota-se a importância em termos de área de plantio dos estados: Mato Grosso, Goiás, São Paulo, Paraná e Rio Grande do Sul. Já a região Norte e Nordeste, com exceção de alguns estados, apresentam regiões com as menores áreas de plantio.

A Figura 9 apresenta a área dos estabelecimentos agropecuários em hectares, conforme o Censo Agropecuário de 2006.

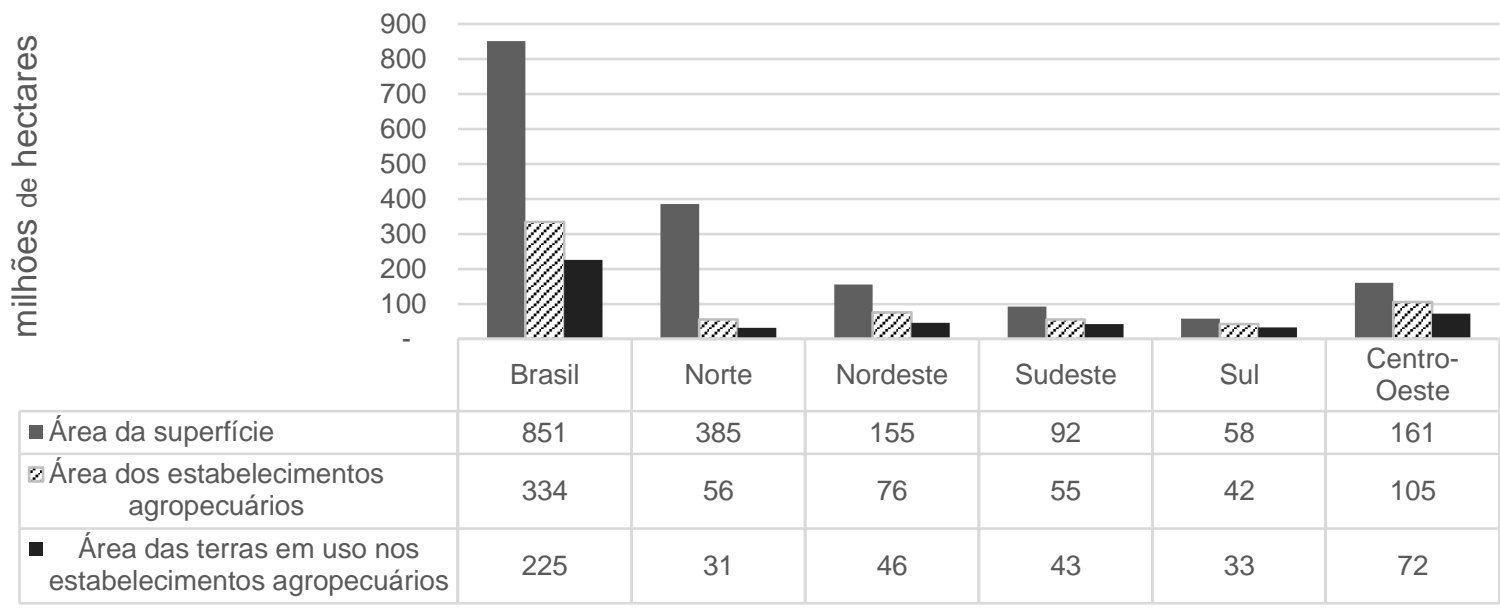

Figura 9. Área da superfície territorial do Brasil, dos estabelecimentos agropecuários e das terras em uso, Brasil, 2006.

Fonte: adaptado de IBGE (2016c). 
O total de terras utilizadas para desempenhar as atividades de agricultura e pecuária, incluso áreas de pastagens, chegava em $225 \mathrm{Mha}$, aproximadamente $26,47 \%$ do território nacional, enquanto as áreas dos estabelecimentos agropecuários aproximavam-se de $39,19 \%$ de solo brasileiro, com 334 Mha, em 2006.

A Figura 10 ilustra o contraste entre a área total de superfície nacional, apresentada por grandes regiões geográficas, e área cultivada com lavouras temporárias e permanentes, as quais estão representadas pelas colunas que se sobrepõem às colunas que as representam a área total graficamente, nos anos de 2007 e 2013.

Ao observar a Figura 10, nota-se que as mudanças no período são brandas, não havendo mudanças drásticas entre as regiões em termos de área agrícola. A região Centro-oeste e a Sul se destacam pelas maiores extensões cultivadas.

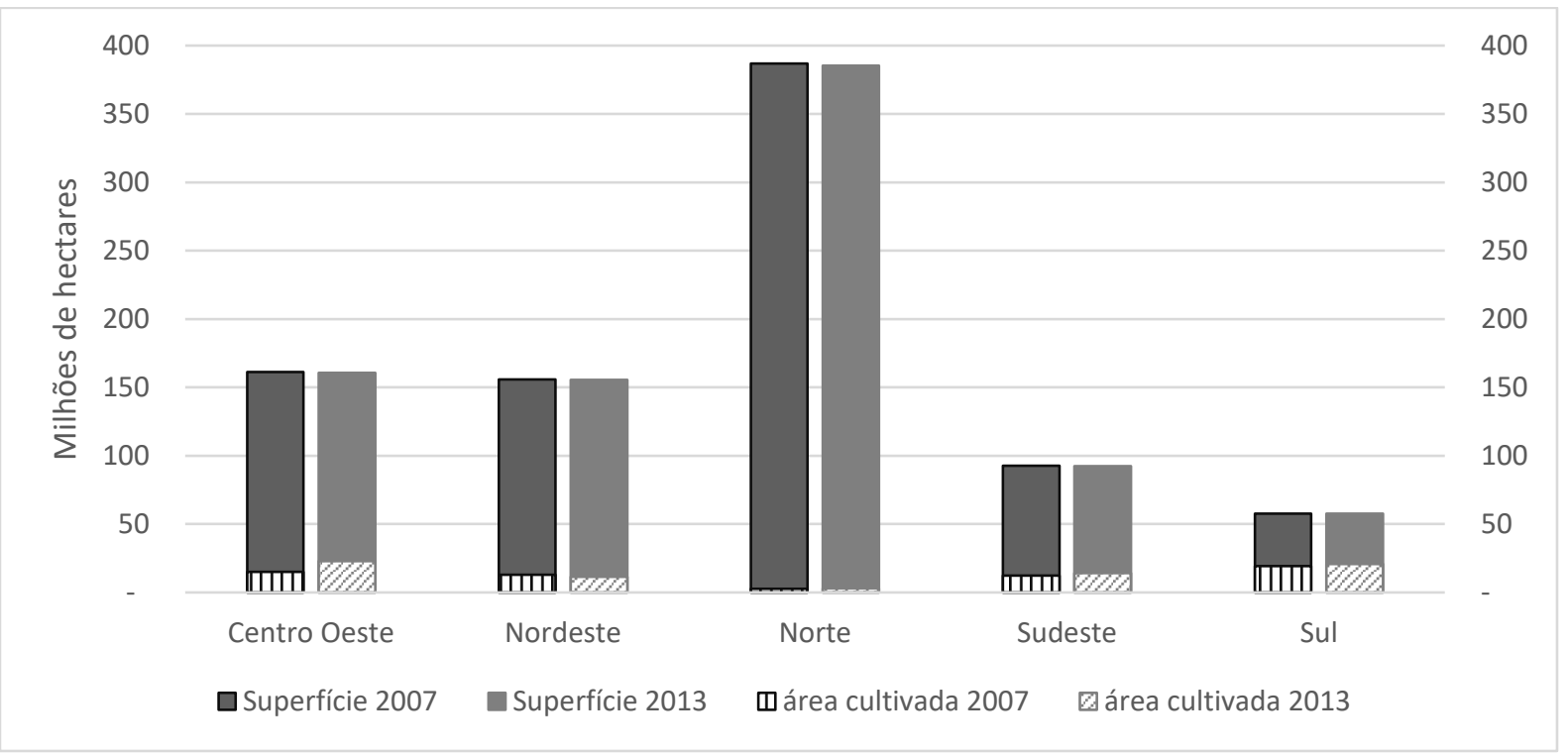

Figura 10. Comparação da área total das terras em uso com lavouras em relação ao total da superfície territorial, por grandes regiões geográficas, em milhões de hectares, Brasil, 2007 e 2013.

Fonte: adaptado de IBGE (2016c).

Contudo, quando se observa um período mais longo, nota-se que houve um avanço da área plantada. As taxas de crescimento das lavouras sobre as fronteiras de produção apresentaram uma tendência positiva no período entre 1992 a 2013 (Figura 11), sendo que sua participação no território total aumentou de 5,50\% em 1996 para 8,50\%, em 2013 (IBGE, 2016c). 
A cultura da soja foi grande responsável pela expansão de áreas cultivaveis no país. Souza et al. (2007) objetivaram avaliar a variação relativa das áreas cultivadas com soja, milho, cana-de-açúcar e pastagem, agrupando com diversas combinações entre eles. Tais autores concluíram que o cultivo de soja tende a substituir as demais culturas, baseando-se no período avaliado entre 1994 e 2005, com base na variação dos preços internacionais relativos, de tal modo que, compensou a predominância da soja. Além disso, o milho também pode perder área para cana de açucar.

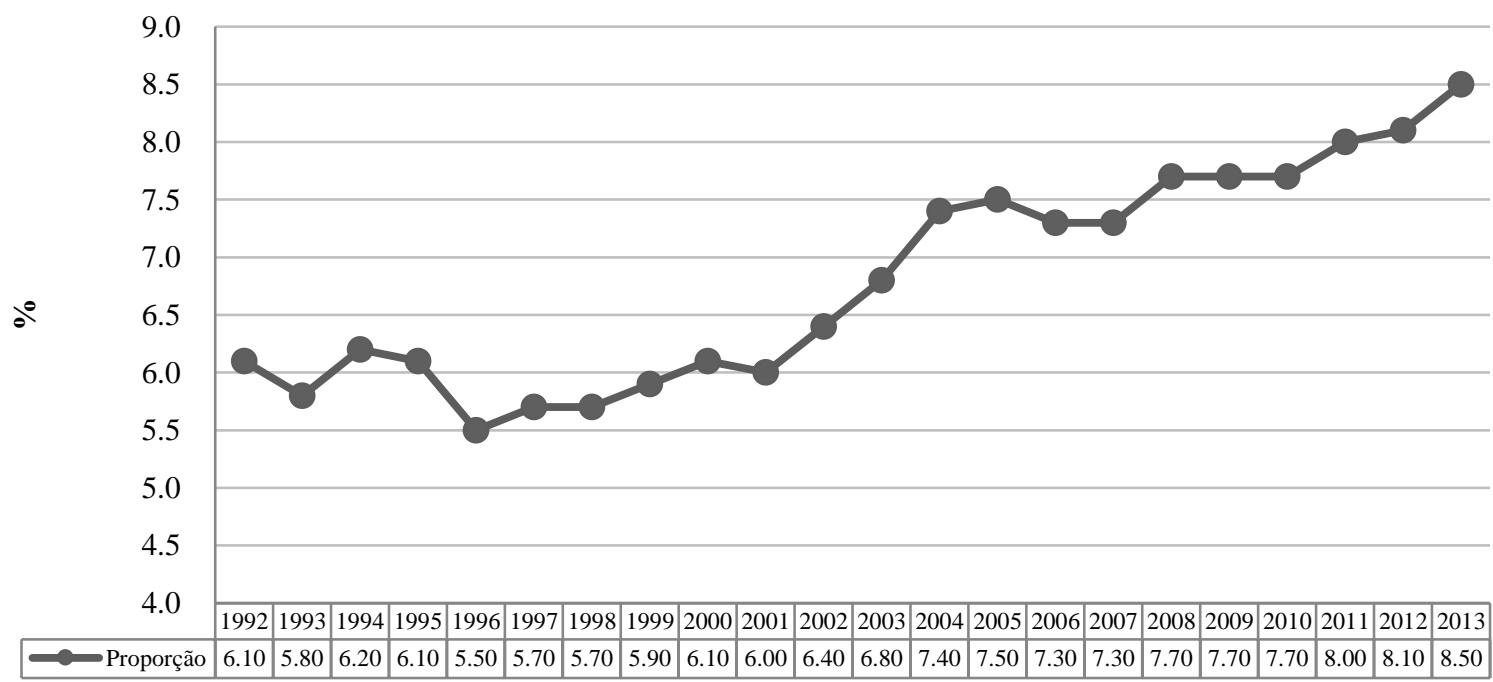

Figura 11. Proporção das terras em uso com lavouras em relação à superfície territorial do Brasil, 1992-2013.

Fonte: adaptado de IBGE (2016c).

A distribuição geográfica das principais culturas no território brasileiro estão dispostas conforme a Figura 12, em que mostra a predominância da pecuária na região Norte e Centro-oeste. Enquanto a soja disputa espaço com o milho na região do cerrado brasileiro e a cana-de-açucar predomina na região sudeste. 


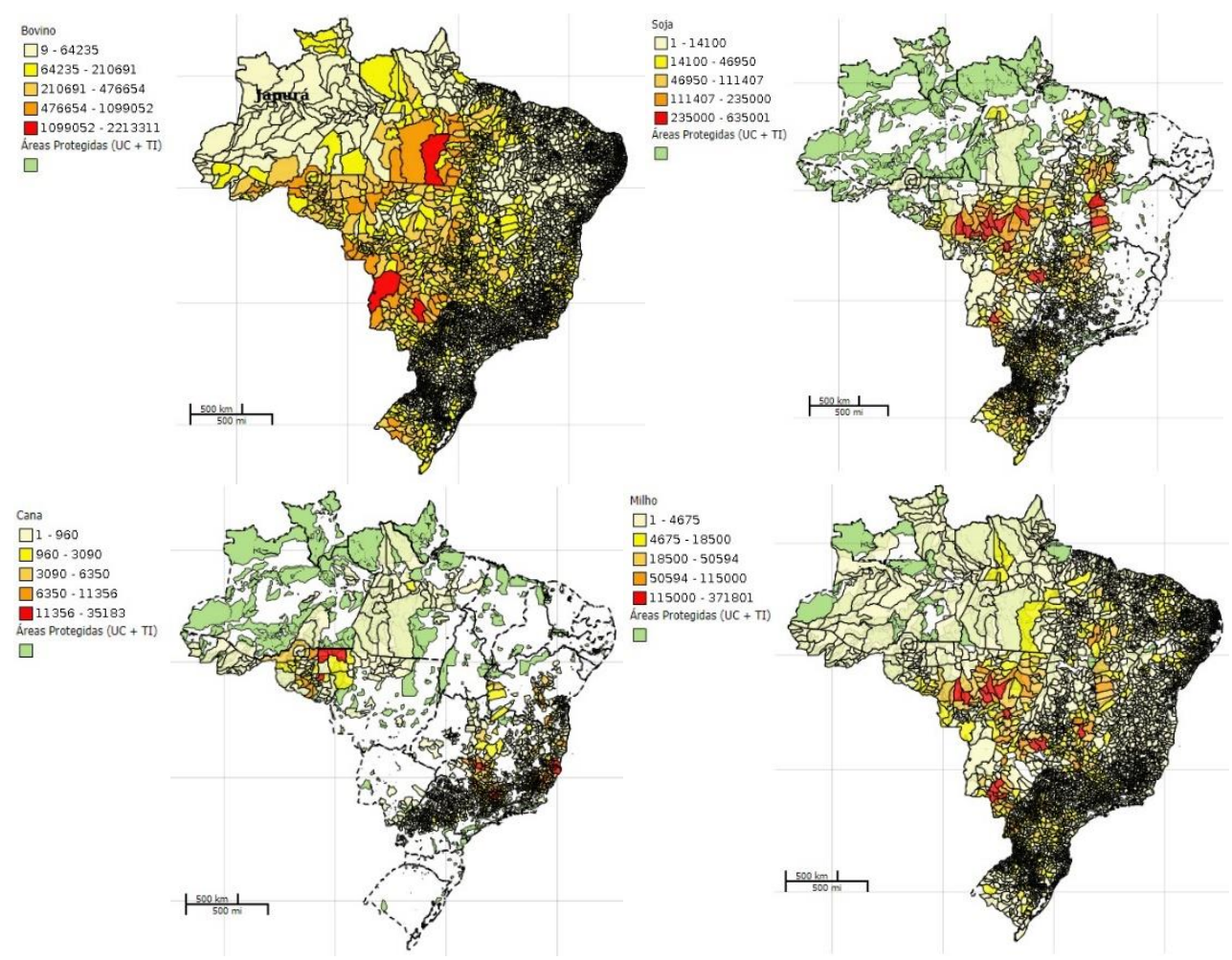

Figura 12. Principais culturas e sua distribuição, no Brasil, 2014.

Fonte: Embrapa, 2014.

Cabe destacar a importância da produção de certos produtos da lavoura nacionalmente e internacionalmente, conforme

Tabela 4 que apresenta a posição nacional perante os demais países na produção de commodities selecionadas. O Brasil se destaca com sua posição de grande produtor mundial, principalmente por sua herança agrícola e vantagens comparativas na produção (em 2016) de : Cana de açúcar (769 milhões de ton ); Soja (96 milhões de ton ); Milho (64 milhões de ton ); Leite (34 milhões de ton ); Mandioca (21 milhões de ton ); Laranjas (17 milhões de ton); Carne de frango (14 milhões de ton ); Arroz (11 milhões de ton ); Carne (9 milhões de ton ); Trigo (7 milhões de ton ) (FAO, 2017).

Dentre tais produtos, também, se destacam no comércio internacional, os que geraram maiores divisas para o Brasil (em 2013), por meio de exportação, quais são: Soja; Açúcar bruto; Carne de frango; soja e produtos derivados; Milho; Carne bovina; Café; Tabaco; Açúcar refinado; Suco, laranja concentrado (FAO, 2017). 
Tabela 4. Classificação da produção de commodities selecionadas, Top 5, entre países, 2016.

\begin{tabular}{|c|c|c|c|c|c|c|c|c|}
\hline Ranking & $\begin{array}{l}\text { Cana de } \\
\text { açúcar }\end{array}$ & $\begin{array}{l}\text { Milhões } \\
\text { de ton }\end{array}$ & Soja & $\begin{array}{l}\text { Milhões de } \\
\text { ton }\end{array}$ & Milho & $\begin{array}{l}\text { Milhões de } \\
\text { ton }\end{array}$ & Mandioca & $\begin{array}{l}\text { Milhões } \\
\text { de ton }\end{array}$ \\
\hline 1 & Brasil & 769 & EUA & 117 & EUA & 385 & Nigéria & 57 \\
\hline 2 & Índia & 348 & Brasil & 96 & China & 232 & Tailândia & 31 \\
\hline 3 & China & 123 & Argentina & 59 & Brasil & 64 & Brasil & 21 \\
\hline 4 & Tailândia & 87 & Índia & 14 & Argentina & 40 & Indonésia & 21 \\
\hline 5 & Paquistão & 65 & China & 12 & México & 28 & Gana & 18 \\
\hline
\end{tabular}

Fonte: adaptado de FAO (2017).

Conforme Sistema Nacional de Cadastro Rural (SNCR) há um total de 5.766.542 imóveis rurais de propriedade particular. A área total dos imóveis rurais é de 521,8 Mha, de modo que as pequenas propriedades correspondem a 29\% dessa área, ou seja, 152,9 Mha (INCRA, 2016). As posses de titularidade particular com até quatro módulos fiscais correspondem a 5,2 milhões de estabelecimentos, 91\% do total no Brasil. A Figura 13 ilustra em percentual a parcela de imóveis rurais registrados e o percentual da área que essas ocupam, classificados em grandes grupos por módulo fiscal. 


\begin{tabular}{|c|c|c|c|c|}
\hline \multirow{9}{*}{$\begin{array}{l}70 \% \\
60 \% \\
50 \% \\
40 \% \\
30 \% \\
20 \% \\
10 \%\end{array}$} & & & & \\
\hline & & & & \\
\hline & & & & \\
\hline & & & & \\
\hline & & & & \\
\hline & & & & \\
\hline & & & & \\
\hline & & & & \\
\hline & $\begin{array}{c}\text { IMÓVEL } \\
\text { PARTICULAR } \\
\text { (un.)* }\end{array}$ & $\begin{array}{l}\text { TOTAL DE } \\
\text { ÁREA (ha)* }\end{array}$ & $\begin{array}{l}\text { IMÓVEL } \\
\text { PÚBLICO } \\
\text { (un.)** }\end{array}$ & $\begin{array}{c}\text { TOTAL DE } \\
\text { ÁREA (ha)** }\end{array}$ \\
\hline Mais de $600 \mathrm{MF}$ & 174 & $11,522,308$ & 387 & $91,028,845$ \\
\hline Mais de 400 a 600 MF & 216 & $4,794,328$ & 126 & $50,417,315$ \\
\hline - Mais de 200 a 400 MF & 1,167 & $14,037,879$ & 302 & $5,572,138$ \\
\hline Mais de 100 a 200 MF & 4,975 & $30,818,041$ & 585 & $4,859,577$ \\
\hline Mais de 50 a 100 MF & 16,918 & $57,004,442$ & 1,050 & $3,739,128$ \\
\hline Mais de 20 a 50 MF & 69,550 & $101,255,661$ & 1,980 & $3,149,747$ \\
\hline Mais de 10 a $20 \mathrm{MF}$ & 119,751 & $69,754,250$ & 1,097 & 804,309 \\
\hline Mais de 4 a 10 MF & 321,772 & $79,719,973$ & 682 & 225,322 \\
\hline$\square$ De 0 a 4 MF & $5,232,019$ & $152,930,238$ & 3,113 & 266,591 \\
\hline
\end{tabular}

Figura 13. Distribuição de imóveis rurais e da área correspondente de titularidade particular e pública por Módulo Fiscal (MF), cadastrados no Sistema Nacional de Cadastro Rural (SNCR), no Brasil, 2014.

Fonte: INCRA (2016).

*Total de imóveis rurais com titularidade particular: 5.766.542 unidades em 521.837.119 ha.

** Total de imóveis rurais com titularidade pública: 9.322 unidades em 160.062.971,85 ha.

Alguns estudos vêm sendo conduzidos com objetivo de projetar as futuras mudanças para o uso da terra.

No Quadro 3, estão listados os principais e mais recentes estudos que desenvolveram modelos visando analisar a alocação do uso da terra no Brasil. As principais projeções são apresentadas na sequência. 


\begin{tabular}{|c|c|c|c|c|}
\hline Referência & $\begin{array}{l}\text { Nome do } \\
\text { modelo }\end{array}$ & Objetivos & $\begin{array}{c}\text { Características - (eq. Geral, } \\
\text { parcial, espacial) }\end{array}$ & Período \\
\hline $\begin{array}{l}\text { WORLD } \\
\text { BANK }\end{array}$ & $\begin{array}{l}\text { BLUM e } \\
\text { SIMBRASIL }\end{array}$ & $\begin{array}{l}\text { Esse estudo objetivou estimar } \\
\text { a demanda futura por terra e } \\
\text { as emissões geradas, por } \\
\text { meio de dois modelos } \\
\text { desenvolvidos: i) O Modelo } \\
\text { Brasileiro de Uso da terra } \\
\text { (sigla BLUM, em inglês, } \\
\text { projeta o uso da terra e a } \\
\text { mudança no uso } \\
\text { da terra); e (ii) SIMBRASIL, } \\
\text { aloca esse uso da terra e } \\
\text { essa mudança no uso } \\
\text { da terra a locais e anos } \\
\text { específicos. }\end{array}$ & $\begin{array}{l}\text { BLUM: } \\
\text { econométrico baseado na } \\
\text { oferta e demanda das } \\
\text { principais culturas (soja, } \\
\text { milho, algodão, arroz, feijão } \\
\text { e cana-de-açúcar, além de } \\
\text { pastagens e matas de } \\
\text { produção); SIMBRASIL: } \\
\text { modelo georreferenciado de } \\
\text { espacialização. }\end{array}$ & $\begin{array}{l}2006- \\
2030\end{array}$ \\
\hline $\begin{array}{l}\text { IIASA, INPE, } \\
\text { IPEA, } \\
\text { UNEP- } \\
\text { WCMC }\end{array}$ & GLOBIOM & $\begin{array}{l}\text { Projeto REDD-PAC, apoiado } \\
\text { pela } \\
\text { Iniciativa Internacional sobre } \\
\text { Clima da Alemanha, com } \\
\text { objetivo de estudar as } \\
\text { políticas para as reduções de } \\
\text { emissões no âmbito do uso } \\
\text { da terra e mudanças no uso } \\
\text { da terra no Brasil, buscou } \\
\text { identificar a importância } \\
\text { crucial } \\
\text { implementação do Código } \\
\text { Florestal. }\end{array}$ & $\begin{array}{l}\text { Modelo de equilíbrio parcial } \\
\text { (Top-down) que se baseia } \\
\text { nos principais setores } \\
\text { terrestres globais } \\
\text { (agricultura, silvicultura e } \\
\text { bioenergia). }\end{array}$ & $\begin{array}{l}2010- \\
2050\end{array}$ \\
\hline $\begin{array}{l}\text { Ferreira } \\
\text { Filho, } \\
\text { Ribera } \\
\text { Horridge } \\
\text { (2015) }\end{array}$ & TERM-BR & $\begin{array}{l}\text { Simulações } \quad \text { sobre } \\
\text { capacidade brasileira de } \\
\text { atender à crescente demanda } \\
\text { mundial por alimentos } \\
\text { enquanto conserva suas } \\
\text { florestas tropicais. }\end{array}$ & $\begin{array}{l}\text { Equilíbrio } \\
\text { computacional multi- } \\
\text { regional do Brasil para } \\
\text { modelar o uso da terra ao } \\
\text { longo de } 20 \text { anos. O modelo } \\
\text { possui um módulo de } \\
\text { mudança de uso da terra } \\
\text { baseado em } \\
\text { uma matriz de transição } \\
\text { obtida a partir de imagens } \\
\text { de satélite }\end{array}$ & $\begin{array}{l}2005- \\
2025\end{array}$ \\
\hline
\end{tabular}

Quadro 3. Principais estudos sobre o uso da terra e mudanças no uso da terra em longo prazo, no Brasil.

Fonte: Elaborado pela autora.

\subsubsection{Projeções do Modelo BLUM e SIMBRASIL (Banco Mundial, 2010)}

Conforme relatório do Banco Mundial (2010), os modelos desenvolvidos, Brazil Land Use Model - BLUM e SIMBRASIL, projetaram a área disponível para expansão das atividades produtivas, sob a hipótese de que não haveria aumento do desmatamento. Combinaram-se ferramentas de sensoriamento remoto aos dados secundários para a caracterização do uso da terra brasileiro. 
A respeito da expansão das atividades, há a possibilidade de conversão para lavouras ou florestas tanto nas atuais pastagens, quanto nas áreas de vegetação remanescente. Conforme Tabela 5, ao acrescentar as áreas do bioma da Amazônia e demais florestas, as apropriadas para expansão de agricultura e florestas de produção totalizam em, aproximadamente, 126 Mha de pastos e 260,6 Mha de vegetação remanescente, sem a necessidade de desmatamento.

Tabela 5. Comparação entre a área total de pastagens e área de vegetação remanescente conversíveis para lavouras/florestas nas regiões do modelo BLUM (em milhões de hectares), Brasil, 2006

\begin{tabular}{lrrr}
\hline \multicolumn{1}{c}{ Região BLUM } & \multicolumn{1}{c}{$\begin{array}{c}\text { Pasto } \\
\text { Total }\end{array}$} & $\begin{array}{r}\text { Pasto conversível para } \\
\text { Lavoura/Florestas }\end{array}$ & $\begin{array}{r}\text { Vegetação remanescente conversível } \\
\text { para Lavouras/Florestas }\end{array}$ \\
\hline Sul & 18,146 & 5,681 & 6,721 \\
Sudeste & 44,053 & 30,335 & 16,415 \\
Centro-Oeste Cerrado & 51,200 & 42,553 & 30,114 \\
Norte Amazônia & 52,551 & 39,079 & 167,017 \\
Nordeste Litorâneo & 10,801 & 0,000 & 0,000 \\
MATOPIBA & 32,138 & 8,365 & 40,319 \\
Brasil & 208,889 & 126,014 & 260,586 \\
\hline
\end{tabular}

Fonte: Banco Mundial (2010).

Ao analisar somente a projeção do uso da terra do primeiro modelo por para as principais culturas somadas às pastagens, exceto florestas de produção, projetase aumento total de área em 6,78\%, com base na área existente em 2006, o que totaliza os 276,8 milhões de ha em 2030 (Tabela 6).

As previsões apontam redução do uso da terra para a cultura de feijão e para pastagem. A área liberada pela redução de pasto chegaria a 1,8 milhões de hectares. Enquanto, o milho a soja e a cana de açúcar necessitarão, juntos, de uma área de 20,5 milhões de ha, para expansão. Para as demais culturas, o crescimento apresenta taxas anuais abaixo de $2 \%$.

Quanto às florestas plantadas, as maiores expansões em percentual ocorreriam nas regiões denominadas MATOPIBA (Maranhão, Piauí, Tocantinse Bahia) e Sul brasileiro com aumento projetado de aproximadamente $124,56 \%$ e $122,28 \%$, respectivamente, entre 2006 e 2030. A região Centro-Oeste Cerrado poderá ter suas áreas de florestas de produção estendidas em $67,08 \%$ e o Norte da Amazônia em 19,29\%. A área da região Sudeste é a que menos cresce em percentual, no entanto contempla a segunda maior área em hectares, nos anos de 
referência. A mesma projeção apresenta um crescimento no Brasil como um todo de $60,37 \%$, ou seja, em 2030 a área ocupada por florestas plantadas chegará a 8,5 Mha, o que corresponderia a apenas $0,99 \%$ do território nacional.

Tabela 6. Uso da terra projetado pelo modelo BLUM para principais culturas e pasto (em milhões de hectares) e variação percentual do período, Brasil, 2006, 2008, 2018, 2030

\begin{tabular}{lrrrrr}
\hline & 2006 & 2008 & 2018 & 2030 & $\Delta \%$ 2006-2030 \\
\hline Algodão & 0,844 & 1,066 & 1,32 & 1,399 & 65,76 \\
Arroz & 3,018 & 2,881 & 2,898 & 3,231 & 7,06 \\
Feijão - 1a safra & 2,694 & 2,857 & 2,38 & 2,394 & $-11,14$ \\
Feijão - 2a safra & 1,529 & 1,143 & 1,281 & 1,328 & $-13,15$ \\
Milho - 1a safra & 9,632 & 9,656 & 9,663 & 10,292 & 6,85 \\
Milho Safrinha & 3,332 & 5,052 & 5,402 & 5,608 & 68,31 \\
Soja & 22,749 & 21,334 & 26,023 & 30,601 & 34,52 \\
Cana-de-açúcar & 6,179 & 8,235 & 10,594 & 12,7 & 105,53 \\
Florestas de produção & 5,269 & 5,887 & 7,74 & 8,45 & 60,37 \\
Agricultura verão & 50,386 & 51,903 & 60,814 & 69,793 & 38,52 \\
Pasto & 208,889 & 205,381 & 203,003 & 207,06 & $-0,88$ \\
Área Agrícola + Pasto & 259,275 & 257,284 & 263,817 & 276,853 & 6,78 \\
\hline
\end{tabular}

Fonte: Banco Mundial (2010).

A área ocupada por florestas de produção serviu como restrição ao modelo BLUM, para as demais projeções. Assim, os resultados estimados para o uso produtivo agropecuário da terra estão na Tabela 7, para o período de 2006 e 2030. Em termos percentuais, as maiores expansões ocorrem no Norte da Amazônia de 56,6 Mha para 70,4 Mha (24,30\%), MATOPIBA (5,37\%) e Nordeste Litorâneo (4,57\%). Os cenários para o Centro-Oeste Cerrado se modificam em $2 \%$ e do Sul em $0,19 \%$. Ao contrário do que ocorre nas demais, regiões, a projeção para o Sudeste mensura uma redução de $1,61 \%$ de sua área produtiva, de 54,8 Mha para 53,9 Mha, em relação ao ano base 2006. Estima-se que a expansão total da área de produção agropecuária brasileira, até 2030 , será em torno de $6,5 \%$, ou seja, totalizando o equivalente a 276,126 milhões de ha, o que resultaria de uma taxa de expansão anual de $0,26 \%$ a partir de 2006 .

Ao analisar as projeções do uso da terra para principais culturas conjuntamente as áreas de pasto e florestas de produção, por região, identifica-se uma significativa redução das áreas de pastagens no Sul, Sudeste, Centro-oeste, 
MATOPIBA, enquanto no Norte da Amazônia e, em menor proporção, no Nordeste Litorâneo há um aumento dessa atividade.

As culturas de maior impacto sobre as mudanças no uso da terra das regiões encontradas pelo modelo serão: soja, com o maior aumento de área $(3,10$ Mha) e floresta de produção (1,161 Mha) na região Sul; cana de açúcar na região Sudeste (3,112 Mha); na região Centro-Oeste Cerrado, aumento na área do cultivo de soja (1,845 Mha), de milho de segunda geração (1,345 Mha) e floresta de produção (1,093 Mha); no Norte da Amazônia cabe destacar o aumento de áreas de pastagens $(12,073$ Mha) e da soja $(1,615)$; cana de açúcar e soja também se expandirão intensamente na região MATOPIBA (1,275 Mha e 1,067 Mha, respectivamente).

As pastagens reduzem-se significativamente nas demais regiões, com exceção no Nordeste Litorâneo. Contudo, esta mesma pesquisa projeta aumento da produtividade total na produção de bovinos em 14,9\%.

Tabela 7. Uso produtivo da terra (culturas, pasto e florestas) nas diferentes regiões e no Brasil (em milhões de hectares) e variação percentual do período, Brasil, 2006, 2008, 2018, 2030

\begin{tabular}{lrrrrr}
\hline Regiões do Modelo BLUM & 2006 & 2008 & 2018 & 2030 & $\Delta \%$ 2006-2030 \\
\hline Brasil & 259,275 & 257,297 & 263,222 & 276,126 & 6,50 \\
Centro-Oeste Cerrado & 61,756 & 61,087 & 61,843 & 62,994 & 2,00 \\
MATOPIBA & 37,295 & 36,815 & 37,678 & 39,296 & 5,47 \\
Nordeste Litorâneo & 14,567 & 14,622 & 14,913 & 15,233 & 4,67 \\
Norte Amazônia & 56,639 & 57,695 & 61,826 & 70,405 & 24,30 \\
Sudeste & 54,845 & 53,517 & 53,747 & 53,96 & $-1,61$ \\
Sul & 34,173 & 33,561 & 33,614 & 34,238 & 0,19 \\
\hline
\end{tabular}

Fonte: Banco Mundial (2010).

A projeção de produção de carne no Brasil, conforme os modelos BLUM e SIMBRASIL, prevê elevação de 35,6\% até 2030, com aumento aproximado dos 9,7 milhões de toneladas em equivalente-carcaça, em 2008, para 13,15 milhões de toneladas em 2030. As projeções também indicam que a produtividade do leite segue a produtividade da carne.

\subsubsection{Projeções do Modelo GLOBIOM-Brasil}

Outro modelo que analisa o uso da terra no Brasil, foi desenvolvido no âmbito do REDD+ no projeto de REDD-PAC, é chamado GLOBIOM-Brasil (REDDPAC, 2015). Trata-se de um modelo de equilíbrio parcial que incorpora informações 
do mapa de vegetação do IBGE, o mapa SOS Mata Atlântica, o MODIS mapa de cobertura da terra, e as estatísticas do IBGE de colheitas, gado e florestas plantadas e considera as exigências do Novo Código Florestal, o qual apresenta impacto global positivo sobre mudanças de cobertura da terra. O modelo cria cinco cenários hipotéticos, conforme mecanismos do Novo Código Florestal: i) BAU: Business as Usual é o cenário contra factual, em que simula resultados de mudança no uso da terra desconsiderando as exigências do Código Florestal; ii) FC: Código Florestal projeta a mudança no uso da terra resultante das exigências do Novo Código Florestal (Lei n 12.651/2012); iii) FCcropCRA: Código Florestal com cotas aplicadas apenas na compensação de áreas de agricultura; iv) FCnoSFA: Código Florestal sem a anistia de pequenas propriedades é o cenário baseado na hipótese de que não haja anistia aos pequenos fazendeiros para recuperação de área de reserva legal; v) FCnoCRA Código Florestal sem as cotas de reserva ambiental, que se baseia no não funcionamento do mercado de CRA.

Essa pesquisa se baseou no mapa de vegetação do IBGE (Apêndice C) para classificar Floresta; Pasto; Culturas; e outras terras naturais (terras ainda não utilizadas). Assim, os resultados do modelo GLOBIOM-Brasil são classificados conforme REDD-PAC (2016):

- Culturas ou terras agrícolas (Cropland): as culturas agrícolas consideradas pelo modelo GLOBIOM são (18 culturas no modelo global e 14 culturas no Brasil): cevada, feijão seco, mandioca, milho, algodão, amendoim, óleo de palma, batata,

- Arroz, soja, sorgo, cana-de-açúcar, batata-doce, trigo.

- Terra natural (Natural Land): áreas de não-florestas de vegetação natural, como terras arbustivas, savanas pouco arborizadas e pastagens naturais;

- Floresta manejada (Managed forest): estas são as florestas que são exploradas de forma sustentável. No Brasil, florestas manejadas são aquelas incluídas no Plano Nacional de Gestão de Florestas Públicas, que é administrado pelo Serviço Florestal Brasileiro;

- Floresta madura (Mature forest): florestas não manejadas que podem ser primárias ou secundárias. Tanto as florestas perenifólias da Amazônia quanto as florestas caducifólias da Caatinga são inclusas nesta classe;

- Floresta Plantada (Planted Forest): plantações de curta rotação, com pouca diversidade de espécies, contando até mesmo, em alguns casos, com uma 
única espécie, e com densidade uniforme de plantio, sendo usadas pela indústria madeireira. $\mathrm{O}$ Brasil tem um número significativo de florestas plantadas com espécies de pinus e eucalipto, localizadas em sua grande maioria na Mata Atlântica; e

- Pastagem (Pasture): áreas com pasto natural ou antrópico usado para criação de gado. Pastagens compõem as maiores áreas de uso da terra no Brasil.

Conforme especificado, os resultados das projeções apontam que a produção animal tende a uma transição para pecuária intensificada. Essa mudança é destacada pela baixa variação da área de pastagem ao mesmo tempo em que registra uma elevação na produção de bovinos no mesmo período. O número de

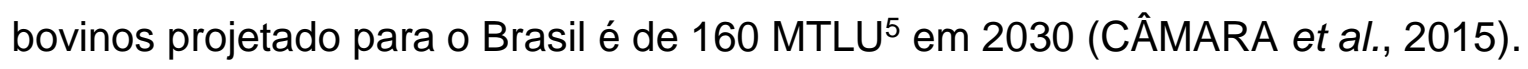

Em síntese, para fins didáticos, cabe destacar os resultados de quatro dos cinco cenários apresentados anteriormente, denominados como: FC; FCnoCRA; FCcropCRA; e FCnoSFA. Nesse estudo o período compreende os anos de 2000 a 2050, mas em resumo reportam-se as alterações entre 2010 e 2030, período foco desta pesquisa.

A tendência de crescimento da agricultura é confirmada pelo GLOBIOM, no qual a expansão de terras cultiváveis é atribuída, principalmente, à expansão de cana, soja e milho em todos os cenários avaliados. Considera-se o Bioethanol como impulsor do aumento da produção de cana até 2030. A produção de soja aumenta de 71,8 milhões de toneladas em 2010 para 123,8 milhões de toneladas em 2030 (CÂMARA et al., 2015).

O cenário $\mathrm{FC}$, que simula a mudança no uso da terra, dada as exigências e mecanismos de compensação da legislação ambiental aprovada em 2012, configurou-se conforme a Tabela 8. Com ampla aplicação do Código Florestal, ocorre regeneração das reservas legais após 2020. Em 2030, foi calculada a regeneração de uma área de 10,4 Mha; entretanto, essa área se estabiliza em 10,8 Mha nos anos seguintes. É fato que o mercado de CRA contribuiria com essa estabilização, uma vez que possibilita que se opte pelo menor custo de oportunidade. Todavia, a área de pastagem segue a uma taxa crescente no período entre 2010 e 2020 (aumento de 5 Mha), para então decrescer 15 Mha até o final do período, 2030. Mostra-se, assim, a influência da legislação sobre as pastagens.

\footnotetext{
${ }^{5}$ Unidade Gado Tropical (TLU) é uma unidade animal usada para agregar diferentes classes de gado. Uma TLU equivale a um animal de $250 \mathrm{~kg}$ de peso vivo. MTLU = Milhões de TLU.
} 
Ainda no cenário FC, que simula a promulgação do Novo Código Florestal a partir de 2020 haverá significativo impacto na área de pastagens, que no período entre 2010 e 2020 aumentam de 240 Mha para 245 Mha, enquanto, se reduz para 230 Mha, na década seguinte. O impacto do Código Florestal sobre o número de bovinos implica em redução de $8 \%$. Isto é compatível com as projeções do Ministério da Agricultura do Brasil, que apontam para um aumento da produtividade das pastagens e um decréscimo de sua área (SOTERRONI et al., 2016).

Em FC, apesar da exigência de regeneração ambiental, ainda é possível o desmatamento legal, em áreas com excedentes de RL e APP. Pelo que também ocorre nesse cenário, há redução de terra natural (anteriormente sem destinação) em 49,72\% e de Floresta Madura em 8,47\%. As culturas são pouco afetadas com a implementação do Novo Código Florestal, apresentando taxa de variação anual positiva, que denota crescimento em todo o período em torno de $2,4 \%$.

Tabela 8. Cenário FC, ampla aplicação do Novo Código Florestal, em milhões de hectares, taxa de crescimento anual e variação percentual no período, Brasil, 2010-2030

\begin{tabular}{lccccr}
\hline Classificação & 2010 & 2020 & 2030 & $\Delta \%$ Anual & $\Delta \%$ Período \\
\hline Culturas (14) & 60,1 & 77,9 & 97,2 & $2,4 \%$ & $61,73 \%$ \\
Terra natural & 54,1 & 39,3 & 27,2 & $-3,4 \%$ & $-49,72 \%$ \\
Floresta manejada & 45,4 & 46,6 & 46,7 & $0,1 \%$ & $2,86 \%$ \\
Floresta madura & 177 & 167 & 162 & $-0,4 \%$ & $-8,47 \%$ \\
Floresta plantada & 7,65 & 9,67 & 11,7 & $2,1 \%$ & $52,94 \%$ \\
Floresta regenerada & 0 & 0 & 10,4 & - & - \\
Pasto & 240 & 245 & 230 & $-0,2 \%$ & $-4,17 \%$ \\
\hline Total & 585 & 585 & 585 & 585 & 585 \\
\hline
\end{tabular}

Fonte: Elaboração própria a partir de Buurman et al. (2015).

O cenário FCcropCRA, conforme Tabela 9, simula a utilização do mercado de CRA somente por agricultores, exceto pecuaristas, que por sua vez possuem um custo de oportunidade mais baixo de utilização da terra. Assim, as CRAs são mais interessantes aos que tem maiores dificuldades de recompor, menos propensos a reflorestamento. Esse cenário, é muito semelhante ao próximo (sem cotas de reserva ambiental), mas a área de floresta regenerada é menor, com 20,7 Mha. Isso ocorre pois nesse cenário os agricultores estarão se utilizando das cotas para 
compensação, ao invés de reflorestamento, como no cenário que desconsidera totalmente o mecanismo de CRA.

Tabela 9. Cenário FCcropCRA, para código florestal sem anistia aos pequenos proprietários, em milhões de hectares, taxa de crescimento anual e variação percentual no período, Brasil, 2010-2030.

\begin{tabular}{lrrrrr}
\hline Classificação & 2010 & 2020 & 2030 & $\Delta \%$ Anual & $\Delta \%$ Período \\
\hline Culturas (14) & 60,1 & 77,9 & 97,4 & $2,4 \%$ & $62,1 \%$ \\
Terra natural & 54,1 & 39,3 & 25,7 & $-3,7 \%$ & $-52,5 \%$ \\
Floresta manejada & 45,4 & 46,6 & 47,4 & $0,2 \%$ & $4,4 \%$ \\
Floresta madura & 177 & 167 & 157 & $-0,6 \%$ & $-11,3 \%$ \\
Floresta plantada & 7,65 & 9,67 & 11,6 & $2,1 \%$ & $51,6 \%$ \\
Floresta regenerada & 0 & 0 & 20,7 & - & - \\
Pasto & 240 & 245 & 224 & $-0,3 \%$ & $-6,7 \%$ \\
\hline Total & 585 & 585 & 585 & $0,0 \%$ & $0,0 \%$ \\
\hline
\end{tabular}

Fonte: Elaboração própria a partir de Buurman et al. (2015).

O cenário FCnoCRA se pauta na hipótese do não funcionamento do mecanismo de compensação de reserva legal, sobre a perspectiva do mercado de CRA ainda não estar devidamente regulamentado, por isso ainda impreciso, conforme discutido anteriormente, é representado na Tabela 10.

Tabela 10. Cenário FCnoCRA, para código florestal sem Cotas de Reserva Ambiental, em milhões de hectares, taxa de crescimento anual e variação percentual no período, Brasil, 2010-2030.

\begin{tabular}{lrrrrr}
\hline Classificação & 2010 & 2020 & 2030 & $\Delta \%$ Anual & $\Delta \%$ Período \\
\hline Culturas (14) & 60,1 & 77,9 & 97,9 & $2,5 \%$ & $62,90 \%$ \\
Terra natural & 54,1 & 39,3 & 23,8 & $-4,0 \%$ & $-56,01 \%$ \\
Floresta manejada & 45,4 & 46,6 & 47,4 & $0,2 \%$ & $4,41 \%$ \\
Floresta madura & 177 & 167 & 155 & $-0,7 \%$ & $-12,43 \%$ \\
Floresta plantada & 7,65 & 9,67 & 11,6 & $2,1 \%$ & $51,63 \%$ \\
Floresta regenerada & 0 & 0 & 27,1 & - & - \\
Pasto & 240 & 245 & 222 & $-0,4 \%$ & $-7,50 \%$ \\
\hline Total & 585 & 585 & 585 & $0,0 \%$ & $0,0 \%$ \\
\hline
\end{tabular}

Fonte: Elaboração própria a partir de Buurman et al. (2015).

Em FCnoCRA, a regeneração florestal é maior em relação ao cenário anterior, resultando em 27,1 Mha ao final do período. Para isso, as terras alocadas com pastagens são convertidas em reflorestadas ou de cultivo agrícola, acarretando em sua redução. Houve, também, redução na área de terra natural $(56,01 \%)$ e de floresta madura $(12,43 \%)$. 
O cenário FCnoSFA, que simula a desobrigação aos pequenos proprietários de terra de recompor área desflorestada é baseado nas discussões e projetos de lei em tramitação, não havendo flexibilidade para a obrigatoriedade de regeneração do passivo ambiental. Conforme a Tabela 11, os resultados para esse cenário são os que mais se distanciam do cenário base. A área de culturas se amplia em 62,56\% ao longo do período de 2010 a 2030. A área de Floresta Regenerada cresce chegando a 27,1 Mha no ano de 2030, semelhante ao cenário anterior; em contrapartida as pastagens caem em $9,17 \%$. Este foi o cenário com maior área de pasto convertida em floresta ou em área agrícola. Como o desmatamento ainda pode ocorrer legalmente, reduzem-se as áreas de terra natural e de floresta madura.

Enquanto os efeitos da SFA impedem o reflorestamento na Mata Atlântica e os do CRA retém restauração na Amazônia e no Cerrado de acordo com o modelo de projeções. No Brasil, as áreas de terra naturais, em 2000, eram em torno de 102 Mha (36 Mha na Amazônia, 43 Mha no Cerrado, 6 Mha na Caatinga e 14 Mha em Mata Atlântica). Nota-se que a maior parte das terras naturais são áreas onde 0 Código Florestal determina $20 \%$ de proteção de vegetação nativa.

Tabela 11. cenário FCnoSFA, para código florestal sem anistia aos pequenos proprietários, em milhões de hectares, taxa de crescimento anual e variação percentual no período, Brasil, 2010-2030

\begin{tabular}{lrrrrr}
\hline Classificação & 2010 & 2020 & 2030 & $\Delta \%$ Anual & $\Delta \%$ Período \\
\hline Culturas (14) & 60,1 & 77,9 & 97,7 & $2,5 \%$ & $62,56 \%$ \\
Terra natural & 54,1 & 39,3 & 21,7 & $-4,5 \%$ & $-59,89 \%$ \\
Floresta manejada & 45,4 & 46,6 & 46,6 & $0,1 \%$ & $2,64 \%$ \\
Floresta madura & 177 & 167 & 162 & $-0,4 \%$ & $-8,47 \%$ \\
Floresta plantada & 7,65 & 9,67 & 11,7 & $2,1 \%$ & $52,94 \%$ \\
Floresta regenerada & 0 & 0 & 27,1 & - & - \\
Pasto & 240 & 245 & 218 & $-0,5 \%$ & $-9,17 \%$ \\
\hline Total & 585 & 585 & 585 & $0,0 \%$ & $0,0 \%$ \\
\hline
\end{tabular}

Fonte: Elaboração própria a partir de Buurman et al. (2015).

No entanto, o Novo Código Florestal não impede o crescimento da área cultivada nas próximas décadas em qualquer um dos cenários testados. No segundo cenário, as projeções apontam que a área de floresta restaurada seria em torno de 40Mha menor em relação ao primeiro cenário em 2050. Na projeção, as perdas mais significativas estão relacionadas ao bioma Caatinga Nordestina, devido a menor proteção ambiental. 


\subsubsection{Projeções do Modelo TERM-BR}

Ferreira Filho, Ribera e Horridge (2015) ressaltam que o Brasil é um importante produtor rural e exportador de várias commodities agrícolas, tais como óleo de soja, açúcar, algodão e carnes. Com uma vasta extensão de florestas com possibilidade de conversão em terras agrícolas, o país sofre uma pressão sobre fronteiras agrícolas apesar do crescente apelo global pela redução do desmatamento, pela mitigação dos gases de efeito estufa e pela preservação da diversidade biológica.

Tal estudo dos autores supracitados, através de simulações realizadas por meio de um Modelo Computável de Equilíbrio Geral (CGE) para o Brasil, chamado TERM-BR, projetado para análise da mudança de uso da terra, por meio de uma matriz de transição que computa endogenamente os efeitos da redução do desmatamento obtidos por dados de imagens de satélite.

Ferreira Filho, Ribera e Horridge (2015) observaram que a expansão agrícola pode ser atribuída às cinco culturas principais: algodão, arroz, cana-deaçúcar, milho e soja, que juntas representaram cerca de $85 \%$ da área de cultivo anual do Brasil em 2012. Além disso, no período entre 2000 e 2012, os principais responsáveis pela expansão foram a soja, o milho e a cana-de açúcar. Nesse período, enquanto a área das culturas aumentou em 18,5 Mha, a área florestada na região amazônica diminuiu 19,5 Mha.

As projeções realizadas para esse estudo indicaram que com a redução do desmatamento simuladas nos cenários 1 e 2 (mais restrito que o 1), conforme Tabela 12, a mudança percentual para culturas selecionadas no período entre 2005 e 2025, e também, o desvio da linha de base causada pelos choques de política extra dos cenários 1 e 2 . Os resultados apontam crescimento da produção agrícola de $50 \%$, em média, enquanto a área de cultivo cresce apenas $12,4 \%$. A área de pastagem aumenta em apenas $4,3 \%$. Consequentemente, a renda da terra aumenta acentuadamente, principalmente em áreas de pastagens, devido a elasticidaderenda mais elevada para a carne de bovino e a conversão contínua de pastagem em terras agrícolas. Esses resultados consideram progresso tecnológico ao longo do tempo.

Observa-se que as projeções indicam maiores variações, no período 20052025, na produção de cana-de-açúcar, mandioca, algodão, milho e soja. Com a 
restrição do desmatamento, os produtos que mais perderam área foram: mandioca; arroz; produtos da pecuária. Tais produtos também registraram maior produtividade da terra.

O PIB nacional diminui devido à redução do desmatamento em apenas 0,05\% para o cenário 1 e 0,09\% para o cenário 2 .

Tabela 12. Resultados do modelo, uso da terra e produção, com aumento de produtividade anual necessário para manter a produção 2025 no nível base

\begin{tabular}{|c|c|c|c|c|c|c|c|}
\hline \multirow{3}{*}{ Produto } & \multirow{2}{*}{$\begin{array}{c}\text { Base: Mudança } \\
\text { percentual } \\
2005-2025 \\
\text { (1) }\end{array}$} & \multicolumn{3}{|c|}{$\begin{array}{l}\text { Cenário 1: variação } \\
\text { percentual } \\
\text { relativa à base em } 2025\end{array}$} & \multicolumn{3}{|c|}{$\begin{array}{l}\text { Cenário 2: Variação } \\
\text { percentual } \\
\text { relativa à base em } 2025\end{array}$} \\
\hline & & (2) & (3) & (4) & (5) & (6) & (7) \\
\hline & Produção & $\begin{array}{c}\text { Uso da } \\
\text { terra }\end{array}$ & Produção & $\begin{array}{l}\text { PTF } \\
\text { Extra }\end{array}$ & $\begin{array}{c}\text { Uso da } \\
\text { terra }\end{array}$ & Produção & $\begin{array}{l}\text { PTF } \\
\text { Extra }\end{array}$ \\
\hline Arroz & 15,3 & $-2,28$ & $-1,11$ & 0,09 & $-4,16$ & $-2,05$ & 0,18 \\
\hline Milho & 64,6 & $-0,83$ & $-0,28$ & 0,03 & $-1,53$ & $-0,52$ & 0,06 \\
\hline Trigo & $-42,4$ & $-0,02$ & $-0,01$ & 0 & $-0,04$ & $-0,07$ & 0,01 \\
\hline Cana de açúcar & 103,7 & $-0,23$ & $-0,1$ & 0 & $-0,42$ & $-0,19$ & 0,01 \\
\hline Soja & 62,3 & $-0,68$ & $-0,54$ & 0,03 & $-1,25$ & $-0,99$ & 0,06 \\
\hline Outros & 42,6 & $-1,09$ & $-0,17$ & 0,02 & -2 & $-0,31$ & 0,03 \\
\hline Mandioca & 70,9 & $-2,39$ & $-0,72$ & 0,15 & $-4,34$ & $-1,38$ & 0,28 \\
\hline Tabaco & 59,2 & $-0,1$ & $-0,03$ & 0,01 & $-0,18$ & $-0,06$ & 0,02 \\
\hline Algodão & 64,7 & $-0,59$ & $-0,25$ & 0,04 & $-1,08$ & $-0,47$ & 0,07 \\
\hline Frutas cítricas & 57,4 & $-0,64$ & $-0,26$ & 0,02 & $-1,18$ & $-0,5$ & 0,03 \\
\hline Café & 28,5 & $-0,72$ & $-0,23$ & 0,01 & $-1,33$ & $-0,42$ & 0,03 \\
\hline Silvicultura & 42,2 & $-0,64$ & $-0,52$ & 0,04 & $-1,23$ & -1 & 0,09 \\
\hline Pecuária & 59,3 & $-1,9$ & $-0,84$ & 0,1 & $-3,48$ & $-1,56$ & 0,19 \\
\hline Leite & 54,9 & $-1,28$ & $-0,58$ & 0,05 & $-2,36$ & $-1,09$ & 0,1 \\
\hline
\end{tabular}

Fonte: Ferreira Filho, Ribera e Horridge (2015).

*Nota: A coluna 1 mostra as variações percentuais dos resultados no cenário Base, de 2005 a 2025. As restantes colunas mostram diferenças percentuais entre um cenário de política e a Base. Por exemplo, no cenário 1, em 2025, a produção de soja é 0,54\% menor que em 2025 no cenário Base. As colunas intituladas "Extra PTF" referem-se a duas simulações suplementares (cenário 1a e cenário 2a); os números mostram o que os incrementos anuais acima da base para a Produtividade Total dos Fatores (PTF), ou mudança tecnológica de redução de entrada) seriam necessários para manter a produção de colheita nos níveis da Base. 


\section{MATERIAL E MÉTODOS}

A metodologia utilizada neste estudo está baseada na integração de dois modelos, para atender os objetivos desta pesquisa: i) por um lado tem-se, para obtenção de projeções de mudança no uso da terra, o modelo GLOBIOM-Brasil, caracterizado por ser híbrido físico-econômico de equilíbrio parcial que incorpora informações geofísicas e; ii) para projeções de cenários econômicos tem-se o TERM-BR, que, por sua vez, se trata de um modelo econômico de Equilíbrio Geral Computável (EGC) para o Brasil, adaptado aos objetivos desta pesquisa, que incorpora uma matriz híbrida, na qual se encontram valores monetários e informações geofísicas do uso da terra, com variáveis regionalizadas.

As projeções realizadas previamente pelo GLOBIOM serão utilizadas como dados de entrada para o modelo TERM-BR. Para a realização desta integração será necessária a realização de uma compatibilização prévia dos dados. Portanto, é importante a compreensão dessa integração e compatibilização. Esses modelos se adequam perfeitamente aos objetivos dessa pesquisa.

As próximas subseções detalham as características específicas de cada um dos modelos, o banco de dados utilizado e, por fim, as simulações propostas.

\subsection{Modelo GLOBIOM-Brasil}

O modelo GLOBIOM-Brasil é uma adaptação baseada no GLObal BIOsphere Management Model (GLOBIOM) desenvolvido, desde 2007, pelo austríaco Internacional Institute for Applied Systems Analysis (IIASA), com base no trabalho no modelo ASM-GHG (Schneider et al., 2007). Esse modelo, de equilíbrio parcial bottom-up ${ }^{6}$, considera os três grandes setores econômicos globais, os quais são agricultura, silvicultura e bioenergia. A adaptação para o âmbito nacional foi desenvolvida no projeto que visa o desenvolvimento e capacidade técnica para a elaboração de estratégias eficientes e ambientalmente relevantes de políticas de uso da terra e de REDD + que, por sua vez, objetiva ir além da Redução de Emissões por Desmatamento e Degradação Florestal (REDD), abrangendo em seu propósito o papel da conservação, manejo sustentável de florestas e aumento dos estoques de carbono florestal (REDD-PAC, 2015).

\footnotetext{
${ }^{6}$ Modelos bottom up utilizam resultados regionais para obter uma agregação em nível nacional.
} 
Os principais pressupostos desse modelo seguem-se no Quadro 4:

\begin{tabular}{|l|l|}
\hline Embasamento teórico & $\begin{array}{l}\text { Teoria neoclássica, em que consiste no ajustamento endógeno dos preços de } \\
\text { mercado para levar ao equilíbrio entre oferta e demanda de cada produto e } \\
\text { região. Quando o equilíbrio é atingido, os agentes não têm interesse para } \\
\text { alterar as suas ações. }\end{array}$ \\
\hline Otimização & $\begin{array}{l}\text { Maximiza a renda dos consumidores e excedentes dos produtores, dadas as } \\
\text { restrições intrínsecas teóricas. }\end{array}$ \\
\hline Preços & $\begin{array}{l}\text { Não são explícitos, mas são dados pela maximização da área total sob a curva } \\
\text { de excedente de demanda em cada região menos os custos totais de } \\
\text { transporte de todas as remessas conforme o equilíbrio do mercado. A diferença } \\
\text { de preço entre duas regiões é explicada somente pelo custo de transporte. Isso } \\
\text { permite que a representação dos fluxos comerciais bilaterais entre regiões, mas } \\
\text { a região não pode importar e exportar para a mesma região. }\end{array}$ \\
\hline Setores & $\begin{array}{l}\text { Centra-se nas culturas, pecuária, silvicultura e bioenergia, outros setores não } \\
\text { são inclusos. Por competir por terra, os setores agrícola e florestal estão } \\
\text { ligados em um único modelo. }\end{array}$ \\
\hline Tipos de bens & $\begin{array}{l}\text { Pressuposto de bens homogêneos. } \\
\text { Resultados }\end{array}$ \\
\hline Período & $\begin{array}{l}\text { A decisão ótima no período t depende de decisões que os agentes tomaram no } \\
\text { período t-1. Quando um novo período começa as condições de uso da terra } \\
\text { são atualizadas com as soluções das simulações do período anterior. O modelo } \\
\text { é atualizado a cada período utilizando os resultados anteriores como valores } \\
\text { exógenos, como o crescimento do PIB e da população. }\end{array}$ \\
\hline
\end{tabular}

Quadro 4. Principais características do modelo GLOBIOM.

Fonte: adaptação de REDD-PAC (2015).

Esse modelo é capaz de indicar características por meio de dados de georreferenciamento, tais como capacidade do sistema agrícola para atender a demanda por alimentos e outros serviços da sociedade; demanda futura de terras agrícolas e demandas relacionadas ao meio ambiente, como necessidades de água, nitrogênio etc.; tendências sobre desmatamento e impacto das medidas para reduzir desmatamento e degradação florestal, emissões de gases de efeito estufa do setor agrícola e da mudança de uso da terra; potencial contributo da bioenergia para a mitigação das alterações climáticas; demanda de água e fornecimento de água para irrigação; custos e benefícios relativos da importação ou exportação de alimentos e matérias-primas; rentabilidade, incentivos e impactos da mudança das práticas de gestão agrícola; adaptação da agricultura às futuras mudanças climáticas. 
Assim, os valores correspondentes a variáveis relacionadas ao uso da terra, bem como as alterações no uso, cultivo de culturas, produção de madeira e número de animais variam de acordo com as condições locais enquanto demanda final, quantidade de processamento, preços, fluxo de comércio são calculados a nível regional.

A escala espacial do modelo é de 5'x5' que corresponde a $10 \mathrm{~km} \times 10 \mathrm{~km}$ na região equatoriana. Desse modo, a cobertura terrestre está dividida em 212.707 unidades de simulação, polígonos com tamanhos que variam em uma grade de resolução espacial entre 5' e 30'. Dessas, 11.003 unidades de simulação correspondem ao território Brasileiro. Um conjunto de células de 5'x5' que compartilham as mesmas características altitude, inclinação, e da terra são denominadas unidades de resposta homogêneos (HRUs).

O estudo feito para o Brasil utilizou-se de diversas fontes, para maior refinamento dos dados: dados produzidos pela NASA e das seguintes instituições públicas brasileiras e organizações não governamentais como EMBRAPA (Empresa Brasileira de Pesquisa Agropecuária), a Funai (Fundação Nacional do Índio), IBGE (Instituto Brasileiro de Geografia e Estatística), INPE (Instituto Nacional de Pesquisas Espaciais), MMA (Ministério do Meio Ambiente), SOS Mata Atlântica, e UFMG / CSR (Centro de Sensoriamento Remoto da Universidade Federal de Minas Gerais). Para a validação das projeções, também foram utilizados dados dos órgãos oficiais brasileiros.

O modelo se preocupou em analisar o Brasil por UF e por biomas terrestres do país: Amazônia (floresta tropical); Cerrado (savana tropical); Caatinga (região árida com floresta decidual); Mata Atlântica (floresta tropical e subtropical); Pantanal (zona húmida); e Pampa (planícies baixas, em sua maioria cobertos por pastagem natural).

Para a calibração das diversas fontes de dados foram utilizados algoritmos que realocam dados que se sobrepõe à área terrestre existente. Assim, uma unidade de simulação que compõe $10 \%$ de um município recebe $10 \%$ de sua área produtiva, dado que exista terra suficiente disponível. Ao haver excedentes, estes são alocados em unidades de simulação vizinhas. O algoritmo tenta encontrar a melhor atribuição possível, usando as restrições do modelo.

A área total de todas as classes de uso da terra (839,3 milhões de hectares) é menor do que a área oficial do Brasil (851,5 Mha), uma vez que as unidades de 
simulação deixam de fora massas de água, como rios e lagoas e áreas protegidas por órgãos ambientais. Assim, as áreas não relevantes para o estudo são desconsideradas. Também foram excluídas do modelo as terras indígenas, que totalizam 698 unidades no Brasil, aproximadamente 13\% da área terrestre do país, uma extensão total de 113,6 Mha. Contabiliza-se então as florestas, áreas de culturas, pastagem e área natural, com cerca de 585 Mha para análise.

Assim, as projeções foram realizadas pelo modelo para os anos 2010, 2020, 2030, 2040 e 2050. Para validação dos resultados, foram comparadas as projeções de $2010 \mathrm{com}$ as estatísticas oficiais sobre desmatamento e produção agrícola, quando se verificou uma diferença entre elas inferior a 10\%. Conforme INPE (2017) o desmatamento na Amazônia no período entre 2001 e 2010 foi de 16,5 Mha, enquanto o modelo GLOBIOM-Brasil projetou 16,9 Mha, o que gera confiança nas projeções para os anos seguintes (REDD-PAC, 2015).

\subsection{Modelo TERM-BR}

O TERM é constituído por uma série de equações interligadas que representam o lado real da economia, tratando cada região como uma economia distinta, sob um sistema de componentes interdependentes (indústria, famílias, investidores, governo, importadores e exportadores). O TERM foi desenvolvido para o estudo de impactos regionais da economia australiana, a partir dele foram realizadas adaptações para análise econômica de equilíbrio geral no Brasil (FACHINELLO, 2008). Segundo Horridge, Madden e Wittwer (2005) esse modelo foi idealizado para a simulação de choques, provocados por determinadas mudanças nas variáveis econômicas, simultaneamente para um grande número de regiões e de setores de atividade econômica.

O TERM-BR é uma estrutura de equações adaptadas inter-regionalmente para o Brasil e foi desenvolvido nos trabalhos de Ferreira Filho e Horridge (2006a; 2006b; 2006c; 2008; 2010; 2011; 2012; 2014) e Ferreira Filho et al. (2007) a partir do modelo ORANI (Dixon et al., 1982), que por sua vez, combinou a eficiência da álgebra linearizada com a precisão das soluções multi-passo por meio do software GEMPACK desenvolvido por Pearson (1988) sob apoio de outros pesquisadores, conforme Horridge, Madden e Wittwer (2005). O TERM-BR possui uma abordagem bottom-up, ou seja, permite que os resultados regionais sejam ponderados para se obter uma agregação em nível nacional. Sua estrutura pode ser estática, para 
analisar um determinado período, ou dinâmica para análise multiperíodo, assim como por exemplo foi utilizado no modelo de Previsão Monash Multi-Regional Forecasting Model, MMRF (Adams et al., 2002 apud Horridge, 2011). No Brasil, entre as análises que utilizaram o TERM-BR é possível citar trabalhos de Fachinello (2008), Pavão (2011), Diniz (2012), Santos (2013) dentre outros, conforme destacam Carvalho e Domingues (2016).

Conforme Ferreira-Filho e Horridge (2014) o TERM-BR funciona como um conjunto de modelos computáveis de equilíbrio geral ligados pelos fluxos comerciais e de trabalho entre regiões. Segundo os autores supracitados é um modelo bastante convencional: as indústrias e os consumidores finais seguem o comportamento de minimização de custos para escolher entre uma variedade de insumos e commodities. As indústrias também minimizam custos na escolha dos fatores primários. Tanto a tecnologia como os preços obedecem aos retornos constantes de escala. Em princípio, o modelo distingue entre atividades (indústrias) e commodities: uma indústria pode produzir uma gama de commodities, mas em as simulações consideram apenas uma.

Os pressupostos do modelo incluem homogeneidade tecnológica dos setores e comercialização entre regiões. Commodities pouco comercializadas são ajustadas conforme a demanda regional (HORRIDGE, MADDEN E WITTWER, 2005).

Assim como o TERM, o modelo de equilíbrio geral adaptado ao Brasil consegue incorporar um grande número de regiões e de setores com a finalidade de verificar as implicações dos efeitos dos choques de variáveis selecionadas em cada região, conforme realizado em Santos (2013) e Ferreira Filho e Horridge (2012), por exemplo.

\subsubsection{Estrutura de dados do modelo TERM-BR}

Segundo Horridge, Madden e Wittwer (2005) a base de dados do modelo é composta por matrizes cujas dimensões são indicadas por índices (s, c, m, i, etc.), conforme o Quadro 5. 


\begin{tabular}{|c|c|c|c|}
\hline Índice & Matriz & Descrição & $\begin{array}{c}\mathrm{N}^{\circ} \text { de } \\
\text { elementos }\end{array}$ \\
\hline S & SRC & Origem (doméstico, importado) & 2 \\
\hline C & COM & Commodities & 38 \\
\hline M & MAR & Margens (comércio, transporte) & 4 \\
\hline I & IND & Indústrias & 38 \\
\hline O & OCC & Ocupações & 10 \\
\hline D & ${ }^{*}$ DST & Regiões de uso (destinação) & 15 \\
\hline R & ${ }^{*}$ ORG & Regiões de origem & 15 \\
\hline P & ${ }^{*}$ PRD & Regiões de margem de produção & 15 \\
\hline F & FINDEM & Demanda Final** & 4 \\
\hline U & USER & Usuários (IND+FINDEM) & 42 \\
\hline
\end{tabular}

Quadro 5. Principais conjuntos do TERM-BR e suas dimensões.

Fonte: adaptação de Fachinello (2008) e Horridge, Madden e Wittwer (2005).

* Os conjuntos DST, ORG e PRD são de fato o mesmo conjunto, nomeado de acordo com o contexto de uso.

** Consumidores, Investidores, Governo e Exportadores

O Quadro 5 permite uma melhor interpretação da Figura 14. Estrutura do banco de dados do modelo Figura 14, que por sua vez, ilustra a estrutura do banco de dados do modelo TERM-BR. A base de dados contém valores dos fluxos de comércio registrados a7: 1) preços básicos, ou seja, preços de produção para produtos domésticos, ou a preços CIF para produtos importados (incluso seguro e frete no valor do produto); 2) preços do produtor (preços básicos+margens de comércio e transporte); 3) preços ao consumidor (preços ao produtor + impostos sobre produto).

Assim, a base de dados de entrada do TERM-BR é organizada da seguinte forma, conforme as matrizes com valores de um período determinado, que geralmente corresponde a um ano, conforme Horridge, Madden e Wittwer (2005) e Fachinello (2008):

- USE (c,s,u,d) é a matriz de demanda, a preço do produtor, para cada produto (c), de origem (s), ou seja, doméstico ou importado, para determinado usuário (u) localizado em uma região de destino (d). Fachinello (2008) traz um exemplo para esclarecer a interpretação do seguinte fluxo de demanda: USE ("café", "dom", “IndCafe", "São Paulo") que indica o uso da commoditie café produzida domesticamente, ou seja, no Brasil, demandada pela indústria de

\footnotetext{
${ }^{7}$ Conforme Horridge (2011, p. 4): "1) Basic values = Output prices (for domestically-produced goods), or CIF prices (for imports); 2) Delivered values = Basic + Margins; 3 ) Purchasers' values = Basic + Margins + Tax $=$ Delivered + Tax".
} 
café de São Paulo. Caso o produto doméstico fosse usado por uma indústria estrangeira, para esse mesmo exemplo, a origem de destino seria o local para escoamento (saída) do produto, ou seja: USE ("café", "dom", "EXP", "São Paulo"), em que São Paulo nesse caso de exportação (EXP) indica um porto ou aeroporto por onde a mercadoria foi despachada para o exterior. A soma das colunas de USE forma a matriz USE_U (c, s, d).

- $\operatorname{TAX}(\mathrm{c}, \mathrm{s}, \mathrm{u}, \mathrm{d})$ matriz de receitas fiscais por commoditie, doméstica e importada, traz o valor agregado dos impostos sobre produtos pagos conforme os fluxos de demanda, da matriz USE.

- MAKE (c, i, d) é uma matriz diagonal que apresenta o valor da produção total de cada commoditie (c), para cada indústria (i) e em cada região (d). A soma das colunas da matriz MAKE resulta na MAKE_I que mostra a produção total de cada bem (c), também apresenta valores por região (d).

- LAB, CAP, LND e PRODTAX representam as matrizes correspondentes à formação da riqueza gerada. LAB (i,o, d) armazena valores sobre a remuneração em cada indústria (i), para cada ocupação (o), por região (d). Enquanto CAP (i,d) contempla a renda do capital de cada indústria (i) em cada região (d), assim como LND (i, d) traz a renda da terra e PRODTAX (i,d) traz os impostos sobre produção.

- VTOT (i,d) corresponde ao valor total da produção para cada indústria (i) em cada região (d). Tal matriz pode ser obtida através da soma para cada indústria da matriz USE e das matrizes LAB, CAP, LND e PRODTAX.

- STOCKS (i, d) é a produção não vendida pela indústria no período (ano) determinado.

- $\operatorname{TRADE}$ (c, s, r, d) considerada matriz chave porque mostra o valor do comércio inter-regional a preços básicos em cada região de origem (r), para cada destino (d), de cada bem (c), seja este doméstico ou importado (s). A diagonal desta matriz apresenta o uso local do bem produzido localmente (onde $r=d$ ). Assim, como o destino dos produtos exportados é registrado como o local do escoamento (local do porto ou aeroporto brasileiro, etc.), os produtos importados têm origem do local de entrada do produto no país. 
- IMPORT (c, r) apresenta o produto total de cada (c) que foi importado por meio do destino (d), que é simplesmente a soma da parte importada de TRADE;

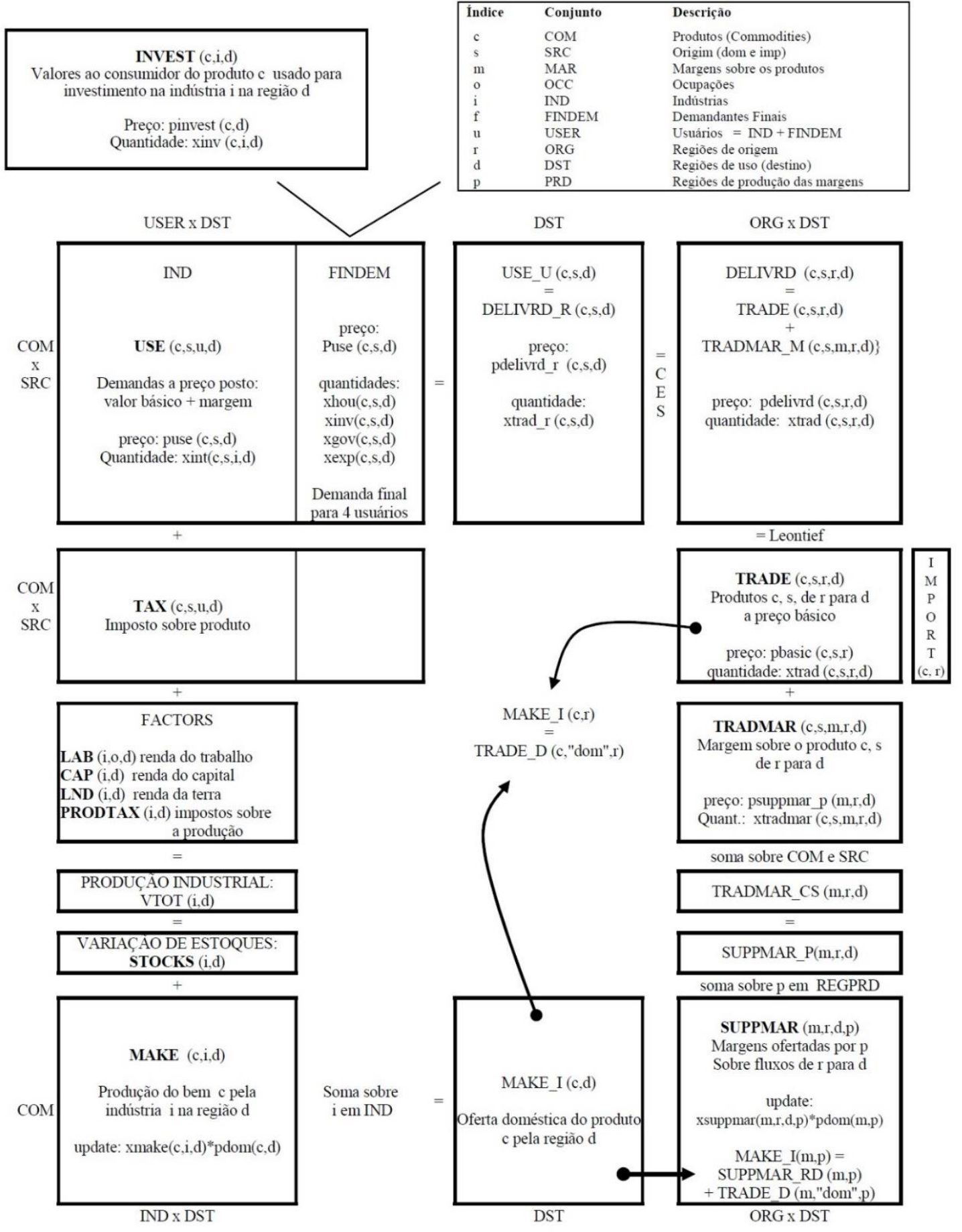

Figura 14. Estrutura do banco de dados do modelo TERM-BR.

Fonte: Fachinello (2008). 
- tradmar (c, s, m, r, d) apresenta o valor das margens de transporte e comércio $(\mathrm{m})$, de cada bem (c), de cada origem (s), necessários para entrega até ao usuário de cada região $(r)$ até o seu destino (d).

- DELIVRD, é a soma de TRADE e TRADMAR, onde se encontram valores a preços do produtor (básico + margens) de todos os fluxos de mercadorias comercializadas internamente e entre regiões.

- SUPPMAR (m, r, d, p) apresenta a onde as margens são produzidas, ou seja, para cada $p$ no PRD. SUPPMAR_P é resultante da soma de SUPPMAR, que deve ser idêntica ao subtotal de TRADEMAR (sobre c em COM e S em SRC).

A estrutura de produção se baseia na minimização de custos para atingir o equilíbrio, conforme os preços, cada indústria em cada região escolhe os insumos para minimizar os custos unitários de produção sujeitos a uma função de produção da forma geral, de acordo com Ferreira Filho, Ribera e Horridge (2015):

$$
\text { Produção }=A_{0} F\left(A_{1} X_{1}, A_{2} X_{2}, \ldots A_{n} X_{n},\right)
$$

Em que, $X_{1}$ a $X_{n}$ representam os insumos de produção (fatores primários e commodities), enquanto $A_{0}$ a $A_{\mathrm{n}}$ são coeficientes tecnológicos (exógenos). Ao longo do tempo o progresso tecnológico pode variar, conforme denotado por seu coeficiente.

llustrada pela Figura 15, na qual o nível de atividade, por sua vez, é definido por uma função Leontief, a qual indica as proporções entre os fatores produtivos, na produção de cada atividade.

Já os fatores primários (terra, trabalho e capital) e a origem dos bens, se domésticos (DOM) ou importados (IMP), são orientados por uma função CES (Constant Elasticity of Substitution). Cabe salientar que os consumidores minimizam o dispêndio através de uma função LES (Linear Expenditure Function), conforme Fachinello e Ferreira Filho, 2010.

A mudança no uso da terra é tratada exogenamente, com o apoio de uma matriz na qual as restrições do uso da terra são impostas, de acordo com as fronteiras existentes. Nesta versão do TERM-BR, os dados de mudança no uso do fator primário Terra foram ajustados por unidade da federação e por cultura no setor agrícola. 


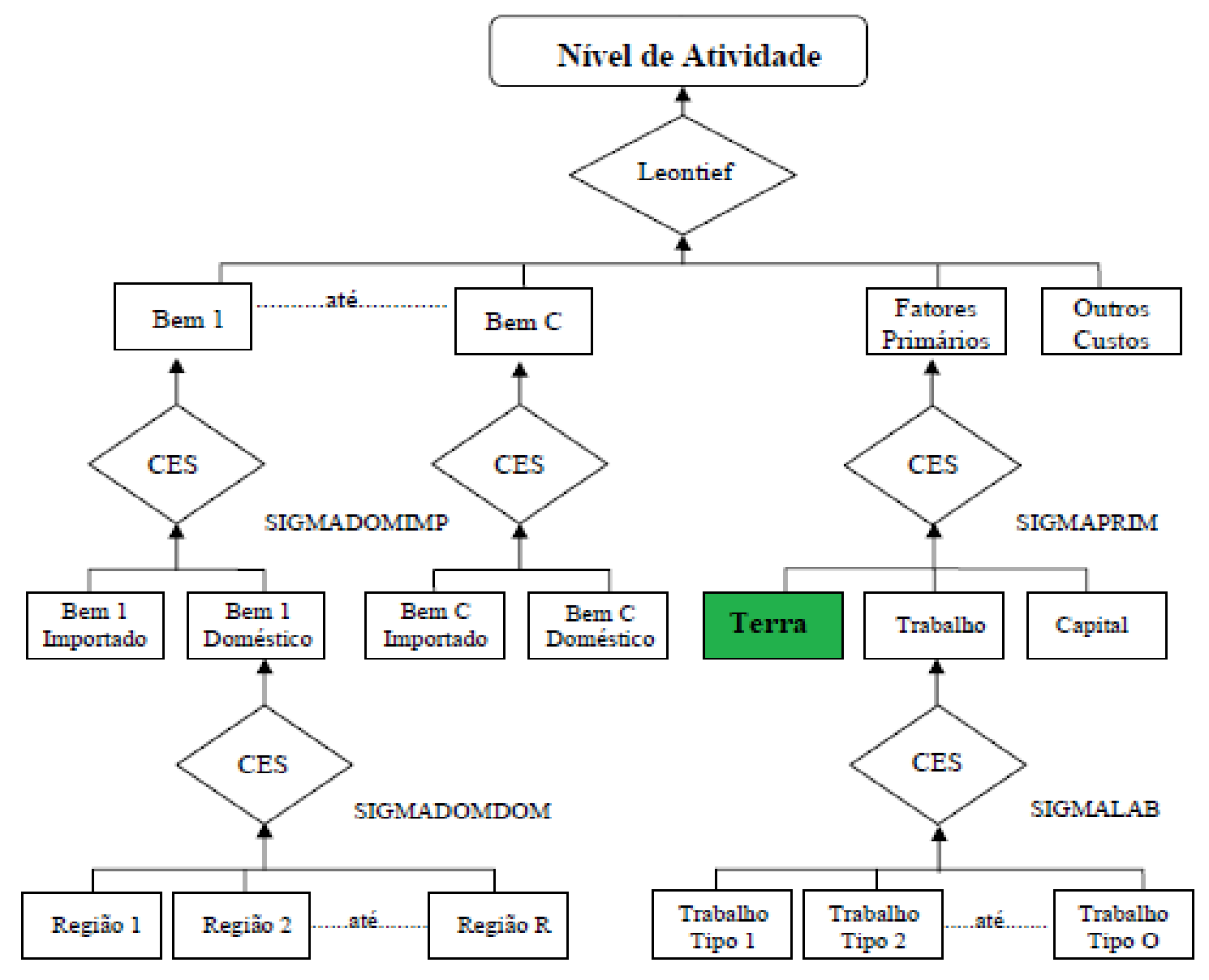

Figura 15. Estrutura de produção do modelo TERM-BR.

Fonte: Adaptado de Fachinello e Ferreira Filho (2010).

A partir das restrições impostas exogenamente ao fator terra, o modelo TERM-BR projeta as variações econômicas, para cada cenário, no período analisado. Como o modelo TERM-BR se baseia em ORANI (DIXON et al., 1982), os seus mecanismos recursivos dinâmicos são, conforme Ferreira Filho, Ribera e Horridge (2015): (i) uma relação entre investimento e estoque de capital, que assume um atraso de um ano; (ii) uma relação positiva entre investimento e taxa de lucro; e (iii) uma relação entre crescimento salarial e emprego regional - com possibilidade de variação nas taxas de desemprego, pelo menos no curto prazo. $O$ modelo é resolvido usando GEMPACK (Ferreira Filho; Horridge, 2015) por meio do RunDynam, que por sua vez é próprio para modelos recursivos dinâmicos.

A mudança no uso da terra é tratada exogenamente, com o apoio de uma matriz na qual as restrições do uso da terra são impostas, de acordo com as fronteiras existentes. Nesta versão do TERM-BR, os dados de mudança no uso do 
fator primário terra foram ajustados por unidade da federação e por cultura no setor agrícola.

As matrizes estão calibradas para análise a partir de 2005. Portanto, esse estudo analisa o comportamento das variáveis econômicas no período compreendido entre 2010 e 2030, frente às restrições de terra que são projetadas a partir de 2020, de acordo com os dados de mudança no uso da terra. Assim, as simulações até 2010 se baseiam em dados históricos, ou seja, as variações dos principais agregados macroeconômicos são impostas ao modelo, que então realiza projeções incorporando as variáveis detalhadas na base de dados desse estudo (seção 3.3).

\subsection{Estratégia de simulação e compatibilização dos dados}

Os dados de entrada relacionados às projeções de mudança no uso da terra a serem utilizados nesta pesquisa foram projetados pelo Modelo GLOBIOM-Brasil. Conforme discutido anteriormente, este modelo projetou variações nas áreas cultivadas compostas por 14 culturas a partir dos anos 2000, para cinco décadas, em cinco cenários (BAU, FC, FCnoCRA, FCcropCRA e FCnoSFA). Para análises econômicas esse estudo utiliza apenas o período entre 2010 e 2030, em quatro cenários.

Assim, a integração dos dois modelos permite resultados baseados em variáveis físicas que detalham a situação do uso da terra e as implicações sobre as variáveis econômicas e sociais, que representam de forma sistêmica a realidade de cada região brasileira, possibilitando captar a heterogeneidade dos impactos causados por esses três mecanismos em que se baseiam os cenários supracitados do Novo Código Florestal. Esta subseção detalha o funcionamento da base de dados de entrada originários do GLOBIOM-Brasil e da compatibilização com o modelo de equilíbrio geral, TERM-BR.

Para as simulações no modelo TERM-BR, o banco de dados em 38 foi agregado em setores, com enfoque no setor agropecuário, e em 15 regiões. 0 modelo ainda detalha 10 tipos de ocupação e uma estratificação de renda das famílias em 10 grupos. A saber, dentro de todos os setores destacam-se aqueles cujos produtos (commodities) foram afetados pela restrição produtiva correspondentes ao modelo GLOBIOM-Brasil, os quais são, conforme Quadro 6: 


\begin{tabular}{|ll|l|}
\hline Setores do TERM-BR & Culturas do GLOBIOM compatibilizadas \\
\hline 1 & Arroz em casca & Arroz \\
\hline 2 & Milho em grão & Milho \\
\hline 3 & Trigo e outros cereais & Trigo, sorgo e cevada \\
\hline 4 & Cana-de-açúcar & Cana-de-açúcar \\
\hline 5 & Soja em grão & Soja \\
\hline 6 & Outros produtos e serviços da lavoura & $\begin{array}{l}\text { Feijão seco, amendoim, batata, batata } \\
\text { doce e óleo de palma }\end{array}$ \\
\hline 7 & Mandioca & Mandioca \\
\hline 9 & Algodão herbáceo & Algodão \\
\hline
\end{tabular}

Quadro 6. Compatibilização de atividades da agricultura do TERM-BR e GLOBIOM-Brasil Fonte: adaptado de Soterroni et al. (2016).

Os demais setores, que não foram listados, como comércio, indústria e serviços não foram impactados diretamente. Em cada um dos cenários de simulação, bem como ocorre com o cenário base, existe uma projeção de crescimento médio anual de cada cultura. Essas variações impactarão nas variáveis econômicas de modo diferente em cada região. Esses impactos serão denotados pelo modelo TERM-BR.

As regiões foram agrupadas conforme as seguintes denominações: Parte do Norte (Parte do NO, onde estão incluídos os estados: Acre; Amazonas; Roraima; e Amapá), Rondônia (RO), Pará e Tocantins (PA-TO), Maranhão e Piauí (MA-PI), Bahia (BA), Mato Grosso (MT), Goiás (GO-DF), Pernambuco e Alagoas (PE-AL), Parte do Nordeste (que abrange os estados: Ceará; Rio Grande do Norte; Paraíba; Sergipe), Mato Grosso do Sul (MS), Minas Gerais (MG), Rio de Janeiro e Espírito Santo (RJ-ES), São Paulo (SP), Paraná (PR), Santa Catarina e Rio Grande do Sul (SC-RS).

Os dados utilizados nessa pesquisa, nesse período selecionado, estão divididos em um cenário base e mais em três cenários de simulação, os quais hipoteticamente apresentam as mudanças no uso da terra em caso de alteração no Novo Código Florestal, conforme a compatibilização do Quadro 7 que renomeia os cenários:

\begin{tabular}{|c|c|}
\hline Cenário do modelo GLOBIOM-Brasil & Adaptação para esta pesquisa \\
\hline BAU & Não se utiliza \\
\hline FC & cenário base \\
\hline FCcropCRA & cenário 1 \\
\hline FCnoCRA & cenário 2 \\
\hline FCnoSFA & cenário 3 \\
\hline
\end{tabular}

Quadro 7 - Compatibilização dos cenários GLOBIOM-Brasil e TERM-BR

Fonte: adaptado de Soterroni et al. (2016). 
Os cinco cenários considerados no modelo GLOBIOM são definidos, conforme SOTERRONI et al. (2016):

i. BAU: Business As Usual é o cenário contra factual, em que simula resultados sem o Código Florestal. Esse seria um caso extremo em que não há controle efetivo sobre aumento ilegal das áreas cultiváveis sobre fronteiras agrícolas, como ocorria no ano 2000, quando se registrou taxas crescentes de desmatamento, com exceção no bioma Mata Atlântica. Tal cenário serve como comparativo aos demais, para identificar a importância da política ambiental. Este cenário é desconsiderado por ser apenas um cenário contra factual.

ii. $\quad F C$ - Cenário base: nesse é considerada a ampla implantação do Novo Código Florestal, tal como aprovado em 2012, com o efetivo funcionamento de todos os seus instrumentos. Também é considerada a aplicação da Lei da Mata Atlântica. Esse cenário é menos restrito perante os demais, pois é possível compensar o desmatamento em outras áreas, sem que seja necessária a recomposição em área produtiva. A anistia de pequenas propriedades também permite a manutenção da área cultivável. Assim, se projetou a total interferência do Novo Código Florestal na mudança do uso da terra. Destaca-se que a implementação dessa Lei ocorrerá a partir de 2020, até 2050, sob a hipótese de implementação efetiva de todos os instrumentos da legislação: restauração florestal como reserva legal; anistia para as pequenas propriedades (SFA) e cotas de reserva ambiental (CRA).

iii. FCcropCRA - cenário 1: denominado CRA parcial, nesse cenário é considerada a utilização parcial das Cotas de Reserva Ambiental (CRA), conforme o Novo Código Florestal, em que são utilizadas para compensação dos déficits registrados em propriedades ou posses rurais com produção agrícola, exceto áreas de pastagem. Esse cenário de CRA parcial considera que o custo de oportunidade dos pecuaristas é mais baixo comparado ao da entrada no mercado de CRA, portanto esses não se utilizam das cotas de reserva ambiental (CRA) para compensar seus passivos em reserva legal. Já, os produtores agrícolas têm maior propensão para comprar cotas de reserva ambiental como forma de não se abster de terras cultiváveis. 
iv. FCnoCRA - cenário 2: denominado Sem CRA, pois remonta o Novo Código Florestal sem o mecanismo de cotas de reserva ambiental para compensação de déficit de reserva legal. Assim, sem que haja a possibilidade de compensação dos passivos registrados na propriedade rural, o proprietário fica obrigado a recompor a vegetação dentro da sua propriedade. Há discussões com base no não funcionamento do mercado de cotas, uma vez que o bioma que tem muita oferta também terá pouca procura; por isso, cogitam-se certas dificuldades para haver negociações de cotas de determinados biomas. Outro questionamento sobre tal mecanismo se dá pela possibilidade legal de não compensar área desmatada na mesma microbacia, ou seja, próximo do ecossistema onde houve a supressão da vegetação nativa, o que acarretaria perdas de espécies de plantas e animais e demais problemas ambientais recorrentes.

v. FCnoSFA - cenário 3: denominado Sem anistia, esse último cenário simula o Novo Código Florestal sem o perdão das multas e sanções aos denominados pequenos proprietários de terra (posses com menos de quatro módulos fiscais). É o cenário baseado na hipótese de que haja obrigatoriedade de recomposição do déficit ambiental ocorrido antes de 22 de julho de 2008. Ainda existe um debate sobre esse quesito devido à grande proporção de propriedades que se enquadram nesse quesito. Tal desobrigação depende da decisão judicial. Da mesma forma, também há um debate sobre a anistia devido a definição na lei de "pequena propriedade", com até quatro módulos fiscais, devido à grande amplitude na variação do tamanho da área da propriedade conforme sua localização, uma vez que os módulos fiscais têm áreas distintas em cada município brasileiro.

Em suma, os resultados de impacto econômico dos cenários de simulação (cenários1, 2 e 3) serão comparados ao cenário base, que simula a mudança no uso da terra resultante das exigências do Novo Código Florestal considerando, após 2020, a implementação efetiva de todos os instrumentos da legislação: restauração florestal como reserva legal, anistia das pequenas propriedades e cotas de reserva (

Quadro 8). Entre 2011 e 2020 considerou-se apenas a proibição do desmatamento ilegal. 


\begin{tabular}{|c|c|c|c|}
\hline \multirow{2}{*}{$\begin{array}{c}\text { Cenário base } \\
\text { Novo Código Florestal (NCF) }\end{array}$} & \multicolumn{3}{|c|}{ Cenários de simulação } \\
\hline & $\begin{array}{c}\text { Cenário } 1 \\
\text { CRA parcial }\end{array}$ & $\begin{array}{l}\text { Cenário } 2 \\
\text { Sem CRA }\end{array}$ & $\begin{array}{c}\text { Cenário } 3 \\
\text { Sem Anistia }\end{array}$ \\
\hline $\begin{array}{c}\text { Novo Código Florestal } \\
\text { Não há desmatamento ilegal } \\
\text { Anistia para propriedades } \\
\text { consolidadas* com até } 4 \text { módulos } \\
\text { fiscais } \\
\text { Cotas de Reserva Ambiental (CRA) } \\
\text { Lei da Mata Atlântica }\end{array}$ & $\begin{array}{c}\text { Cenário base, } \\
\text { exceto: } \\
\text { Cotas de Reserva } \\
\text { Ambiental (CRA) } \\
\text { apenas para } \\
\text { agricultores } \\
\text { (exclui } \\
\text { pecuaristas) }\end{array}$ & $\begin{array}{c}\text { Cenário base, } \\
\text { exceto: } \\
\text { Cotas de Reserva } \\
\text { Ambiental (CRA) }\end{array}$ & $\begin{array}{l}\text { Cenário base, } \\
\text { exceto: } \\
\text { Anistia para } \\
\text { propriedades } \\
\text { consolidadas* } \\
\text { com até } 4 \\
\text { módulos fiscais }\end{array}$ \\
\hline
\end{tabular}

Quadro 8. Cenários de simulação no modelo de equilíbrio geral.

Fonte: adaptado de Soterroni et al. (2016).

De outro modo, o Quadro 9 apresenta os mecanismos considerados em cada cenário de simulação. Assim, é possível identificar quais as políticas de cada um dos quatro cenários. As diferenças resultantes serão exatamente a interferência de cada mecanismo de política do Novo Código Florestal.

\begin{tabular}{|l|c|c|c|c|}
\hline Mecanismos & $\begin{array}{c}\text { cenário base } \\
\text { NCF }\end{array}$ & \multicolumn{3}{|c|}{ cenários de simulação } \\
\cline { 3 - 5 } & & $\begin{array}{c}\text { cenário 1 } \\
\text { CRA } \\
\text { parcial }\end{array}$ & $\begin{array}{c}\text { cenário 2 } \\
\text { Sem CRA }\end{array}$ & $\begin{array}{c}\text { cenário 3 } \\
\text { Sem anistia }\end{array}$ \\
\hline Lei da Mata Atlântica & Sim & Sim & Sim & Sim \\
\hline Desmatamento ilegal & Não & Não & Não & Não \\
\hline Terras privadas no AM & $20 \%$ & $20 \%$ & $20 \%$ & $20 \%$ \\
\hline Anistia de pequenas propriedades & Sim & Sim & Sim & Não \\
\hline CRA em áreas agrícolas & Sim & Sim & Não & Sim \\
\hline CRA em áreas de pecuária & Sim & Não & Não & Sim \\
\hline Reflorestamento & Sim & Sim & Sim & Sim \\
\hline
\end{tabular}

Quadro 9. Cenários de simulação conforme suas considerações.

Fonte: adaptado de Soterroni et.al (2016).

É interessante observar que cada mecanismo atinge um grupo diferente de produtores rurais, em diferentes regiões. A mudança no uso da terra ocorrida em cada um dos três cenários, comparada ao cenário base, pode ser ilustrada em alguns produtos da agropecuária, por exemplo: soja, bovinos e arroz. A Figura 16. Variação na área de cultivo de soja nos cenários 1, 2 e 3, respectivamente, em que as cores mais fortes apontam o quantil de maior mudança positiva, ou seja, onde as áreas mais se ampliaram para o cultivo desse produto. A configuração da produção de soja se diferencia em cada estado a medida em que se restringe o uso da terra, atingindo produtores distintos. 


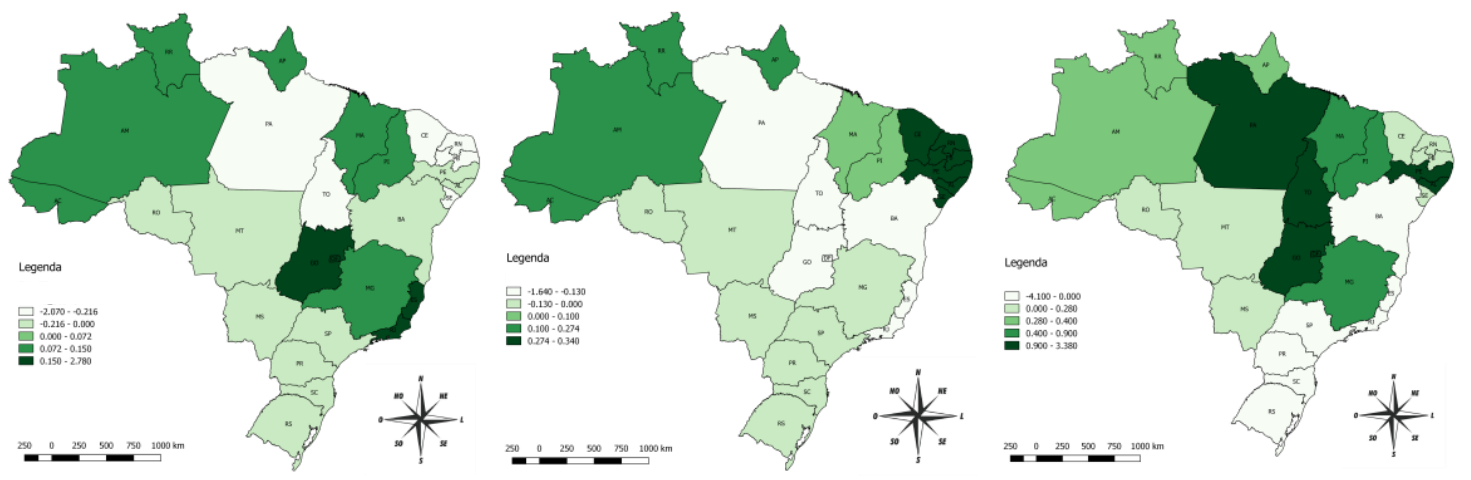

Figura 16. Variação na área de cultivo de soja nos cenários 1, 2 e 3, respectivamente, comparados ao cenário base.

Fonte: elaboração própria.

Assim, ao desconsiderar a possibilidade de compensação de reserva legal por meio das CRAs aos pecuaristas (cenário 1), nota-se um potencial de crescimento da produção de soja no estado de Goiás e do Espírito Santo. Ao desconsiderar totalmente o mecanismo de compensação por meio das CRAs (cenário 2), a soja teria maior produção em solo nordestino, comparado ao cenário base. Em caso da não anistia (cenário 3) o cerrado brasileiro teria maior potencial de produção da soja, enquanto o estado de São Paulo e o sul brasileiro, perderia sua posição pela a maior restrição de terras, comparados ao cenário base.

As diferenças nas restrições do uso da terra afetam, também drasticamente, a configuração da criação de bovinos, conforme ilustra a Figura 17.
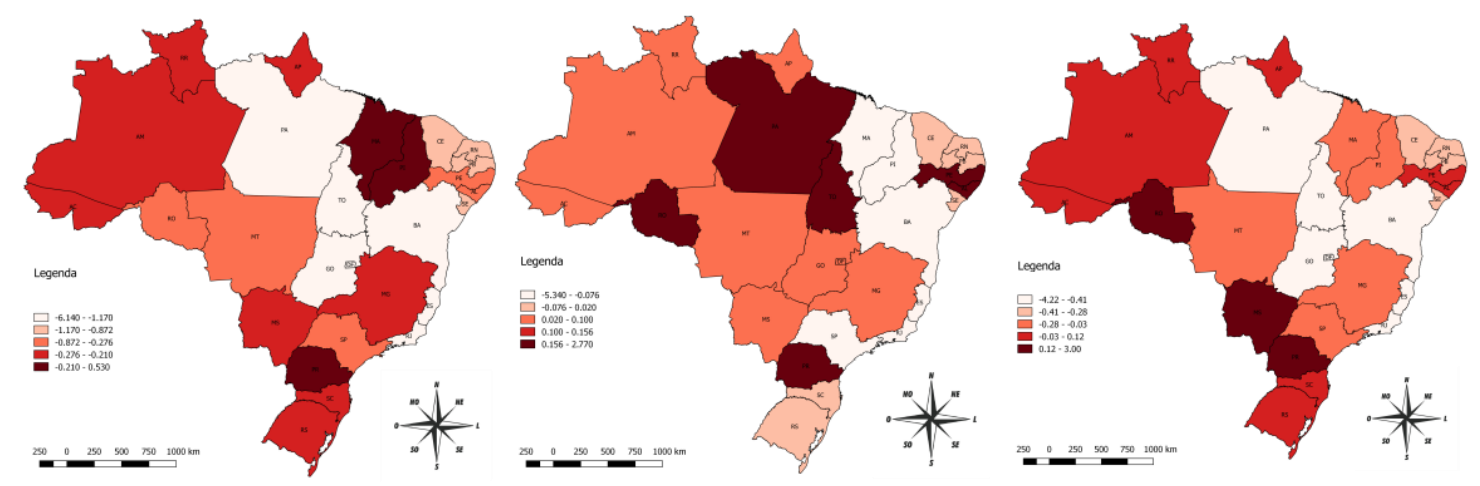

Figura 17. Variação na área da criação de bovinos nos cenários 1,2 e 3, respectivamente, comparados ao cenário base.

Fonte: elaboração própria.

Já para o cultivo de arroz, a produção não se altera significativamente, comparada ao cenário base, pois a variação da área produtiva em hectares é muito pequena, como apresentado a seguir nas Tabelas 13 a 15. A Figura 18 ilustra onde 
essas pequenas variações ocorreram, classificadas por quantil, conforme as projeções dadas pelo modelo GLOBIOM-Brasil.

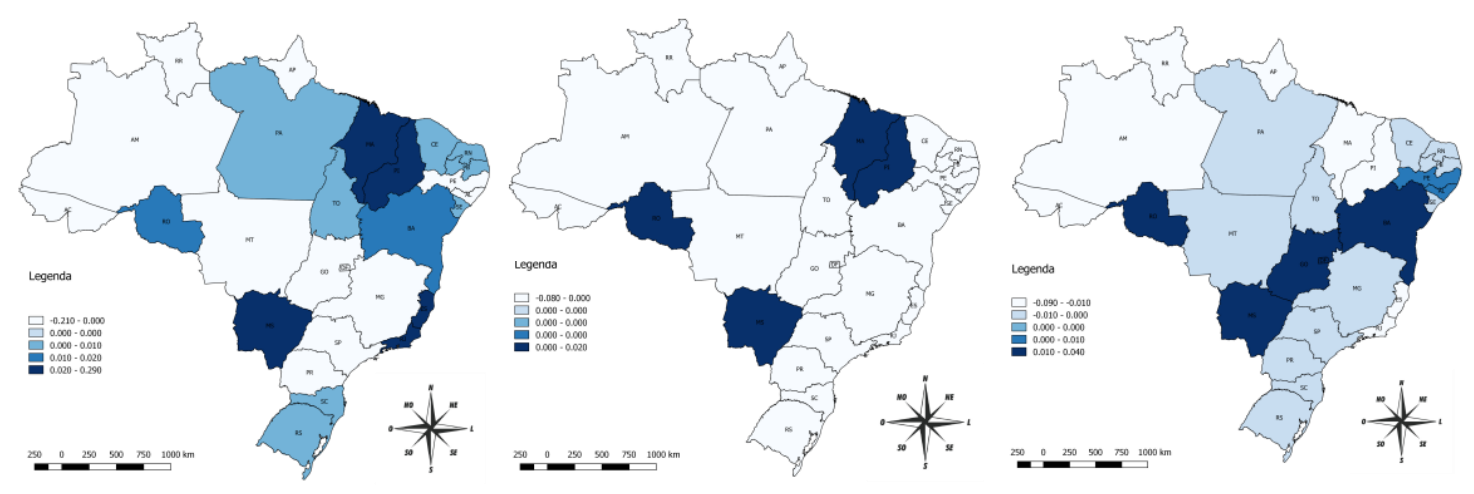

Figura 18. Variação na área de cultivo de arroz nos cenários 1, 2 e 3, respectivamente, comparados ao cenário base.

Fonte: elaboração própria.

Cabe salientar que as restrições de terra dependem de uma série de fatores exógenos, inerentes ao modelo GLOBIOM-Brasil. Outras variações importantes, relacionadas ao cenário base estão expostas a seguir.

As Tabela 14 e 15 apresentam, para os respectivos cenários 1,2 e 3, as variações da área de cultivo, por grupos formados por unidade da federação (UF) e por produtos selecionados, os quais estão dentre as 14 culturas do modelo GLOBIOM-Brasil. Foram destacadas as mudanças percentuais acima ou abaixo do valor absoluto de $1 \mathrm{Mha}$, que denotam as culturas mais sensíveis às políticas simuladas. Notam-se, assim, para as três simulações, as maiores mudanças no campo da soja e no dos bovinos e outros animais.

No cenário 1, o qual considera as CRAs parcialmente, a

Tabela 13 apresenta as principais variações, por grupos formados por unidade da federação (UF) e por produtos selecionados, os quais estão dentre as 14 culturas do modelo GLOBIOM-Brasil, considerados na atual pesquisa. A região denominada Parte do NO (Acre; Amazonas; Roraima; e Amapá) se beneficia com o aumento da área de bovinos (2,77 Mha) e demais culturas. 
Tabela 13. Mudança na área de cultivo (Mha), por UF, em cenário 1- CRA parcial - Brasil (20102030)

\begin{tabular}{|c|c|c|c|c|c|c|c|c|c|}
\hline UF & 旁 & 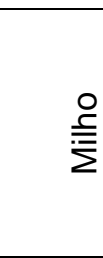 & 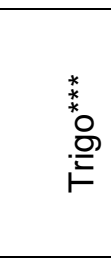 & 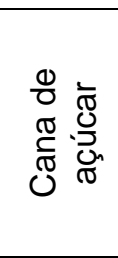 & $\frac{\pi}{8}$ & 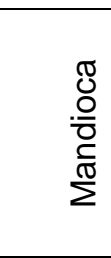 & $\begin{array}{l}\frac{0}{2 \pi} \\
\frac{0}{0} \\
\frac{0}{2}\end{array}$ & 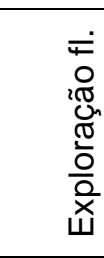 & 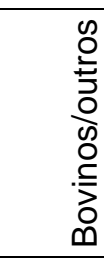 \\
\hline RO & 0,02 & 0 & 0 & 0 & $-0,02$ & 0 & 0 & 0 & 0,08 \\
\hline Parte do NO* & 0,01 & 0 & 0 & 0,04 & 0 & 0,02 & 0 & 0 & 2,77 \\
\hline PA-TO & $-0,08$ & 0,01 & 0 & $-0,03$ & $-1,05$ & $-0,26$ & 0 & $-0,06$ & $-5,34$ \\
\hline MA-PI & 0,01 & 0 & 0 & $-0,04$ & 0,1 & 0,01 & 0,01 & $-0,05$ & $-0,24$ \\
\hline PE-AL & 0 & 0 & 0 & $-0,03$ & 0 & 0 & 0 & 0 & $-0,09$ \\
\hline BA & 0 & 0 & 0 & $-0,01$ & 0,13 & $-0,02$ & 0 & $-0,01$ & 0,1 \\
\hline Parte do $\mathrm{NE}^{\star *}$ & 0 & 0,01 & 0 & $-0,02$ & 0 & 0 & 0 & 0 & 0,17 \\
\hline MG & 0 & 0,05 & 0 & 0,12 & 0,34 & 0 & 0 & $-0,03$ & 0,2 \\
\hline RJ-ES & 0 & 0 & 0 & $-0,04$ & 0 & 0 & 0 & 0 & 0,02 \\
\hline SP & 0 & $-0,04$ & 0,01 & 0,19 & 0 & 0,03 & 0 & 0 & 0,08 \\
\hline PR & 0 & $-0,02$ & 0,03 & $-0,01$ & $-0,09$ & 0 & 0 & 0 & 0,05 \\
\hline SC-RS & $-0,01$ & $-0,02$ & $-0,01$ & 0 & $-0,13$ & 0,02 & 0 & $-0,03$ & 0,1 \\
\hline MS & 0 & 0,01 & 0 & $-0,05$ & 0,31 & 0,01 & 0 & $-0,02$ & $-0,02$ \\
\hline MT & $-0,02$ & $-0,08$ & 0 & $-0,08$ & $-0,73$ & $-0,11$ & 0 & 0,04 & $-3,59$ \\
\hline GO-DF & 0 & 0,05 & 0 & $-0,02$ & $-1,64$ & 0,01 & 0 & 0,01 & 1,42 \\
\hline
\end{tabular}

Fonte: Elaboração própria.

*Parte do NO: Acre; Amazonas; Roraima; e Amapá

** Parte do NE: Ceará; Rio Grande do Norte; Paraíba; Sergipe

${ }^{* * *}$ Incluso outros cereais.

Ainda no cenário 1, os estados de RO, BA, Parte do NE (Ceará; Rio Grande do Norte; Paraíba; Sergipe), MG, SP, MS obtiveram saldo positivo em áreas cultiváveis, enquanto PA-TO perdem grande área produtiva (5,34 e 1,05 Mha, respectivamente). O estado do MT também sofre grande perda de área produtiva, em todos os produtos destacados, exceto Exploração Florestal.

No cenário 2, sem o mecanismo de CRA, os estados de RO, Parte do NO (Acre; Amazonas; Roraima; e Amapá), Minas Gerais expandem sua área de cultivo, sem perdas. São regiões que ainda possuem área para desmatamento legal. Em contrapartida, os estados PA-TO, PE-AL, MS e, novamente, MT sofreriam maiores perdas de área cultivável, reduzindo suas áreas em relação ao cenário base. PA TO e MT no cultivo de soja, mostraram-se fortemente sensíveis à impossibilidade de compensação de RL, enquanto a soja se expandiria em Santa Catarina, Rio Grande do Sul; e Goiás-DF, segundo essa simulação. 
Cabe considerar que as regiões Norte e Nordeste ainda concentram maior área de ativo ambiental ${ }^{8}$ em relação às demais regiões, no âmbito biogeográfico o Cerrado, a Caatinga e a Amazônia possuem maiores áreas sem designação, não protegidas pela legislação ambiental brasileira por meio de unidades de conservação, terras indígenas, APPs e RL, ou outros instrumentos similares.

Tabela 14. Mudança na área de cultivo (Mha), por UF, em cenário 2 - Sem CRA - Brasil (2010-2030)

\begin{tabular}{|c|c|c|c|c|c|c|c|c|c|}
\hline UF & $\frac{N}{\frac{N}{2}}$ & $\frac{\stackrel{\circ}{\equiv}}{\stackrel{\sum}{\Sigma}}$ & 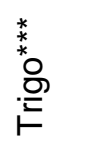 & 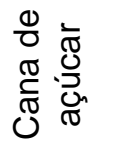 & $\begin{array}{l}\frac{\pi}{\sigma} \\
\stackrel{\infty}{\infty}\end{array}$ & $\begin{array}{l}\frac{\pi}{0} \\
\frac{0}{0} \\
\frac{\pi}{2} \\
\sum\end{array}$ & $\begin{array}{l}\frac{i \pi}{0} \\
\frac{0}{0} \\
\frac{0}{4}\end{array}$ & 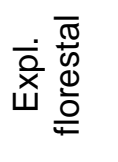 & 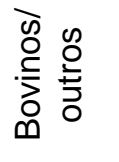 \\
\hline $\mathrm{RO}$ & 0,03 & 0 & 0 & 0 & 0,01 & 0 & 0 & 0 & 0,21 \\
\hline Parte do NO* & 0,02 & 0 & 0 & 0,11 & 0,01 & 0,03 & 0 & 0 & 3,00 \\
\hline PA-TO & $-0,08$ & 0,02 & 0 & 0,02 & $-0,74$ & $-0,21$ & 0 & 0,06 & $-4,22$ \\
\hline MA-PI & $-0,09$ & 0 & 0 & $-0,05$ & 0,74 & 0,03 & 0,01 & 0,08 & $-0,04$ \\
\hline PE-AL & 0 & 0 & 0 & 0,01 & 0 & 0 & 0 & 0 & $-0,24$ \\
\hline BA & $-0,01$ & 0 & 0 & 0,04 & 0,40 & 0,01 & $-0,01$ & 0,01 & 0,12 \\
\hline Parte do NE** & 0 & 0,22 & 0 & 0,02 & 0 & 0 & $-0,01$ & 0 & 0,41 \\
\hline MG & 0,01 & 0,10 & 0 & 0,10 & 0,94 & 0 & 0 & 0,01 & 0,11 \\
\hline RJ-ES & 0 & 0 & 0 & 0,03 & 0 & 0 & 0 & 0 & $-0,02$ \\
\hline SP & 0 & 0,14 & 0 & $-0,15$ & 0,08 & 0 & 0 & 0,01 & $-0,09$ \\
\hline PR & 0 & 0,02 & $-0,02$ & $-0,01$ & 0,53 & $-0,04$ & 0 & 0 & $-0,18$ \\
\hline SC-RS & 0,04 & $-0,06$ & $-0,09$ & 0 & 3,38 & $-0,01$ & 0 & 0,01 & $-0,59$ \\
\hline MS & 0 & 0,02 & $-0,01$ & $-0,35$ & 0,28 & 0,01 & 0 & $-0,05$ & $-0,31$ \\
\hline MT & 0,02 & $-0,01$ & 0 & 0,05 & $-4,10$ & 0 & 0 & $-0,11$ & $-3,56$ \\
\hline GO-DF & 0 & $-0,16$ & 0 & 0,29 & 1,14 & 0 & 0 & 0,08 & $-0,41$ \\
\hline
\end{tabular}

Fonte: Elaboração própria.

*Parte do NO: Acre; Amazonas; Roraima; e Amapá.

** Parte do NE: Ceará; Rio Grande do Norte; Paraíba; Sergipe.

*** Incluso outros cereais.

No cenário 3, sem que haja anistia das sanções aos produtores rurais enquadrados na Lei de crimes ambientais, a restrição na área produtiva se mostra bastante diferente dos cenários anteriores, principalmente na pecuária, onde todos os estados perdem área para criação dos bovinos, com destaque em GO-DF. Os estados MA-PI, em Parte do NE e SC-RS se mostram os únicos da federação com saldo positivo em área de cultura.

Nesse cenário 3 há uma perda de área de pastagem mais expressiva comparativamente aos primeiros cenários. Sem anistia, onde as restrições se tornam relativamente maiores, o cultivo da soja sofre perda em diversas regiões, tais como em Goiás -DF (2,07 Mha); Mato Grosso do Sul (0,23 Mha); Minas Gerais (0,16 Mha); São Paulo (0,09 Mha); e Mato Grosso (0,08 Mha). Em contrapartida, a área da soja se expandiria em Santa Catarina-Rio Grande do Sul (2,78 Mha); PA-TO (0,47 Mha);

\footnotetext{
${ }^{8}$ Ver Scaramuzza et al. (2016) e Apêndice A.
} 
Bahia (0,15 Mha); Paraná (0,13 Mha); e em Maranhão-Piauí (0,12 Mha). Os resultados mostram que os produtos milho e cana-de-açúcar são relativamente mais sensíveis às alterações nesse terceiro cenário de política ambiental.

Tabela 15. Desvio percentual da área de cultivo e por UF, dado cenário sem anistia, Brasil, 2010 2030

\begin{tabular}{|c|c|c|c|c|c|c|c|c|c|c|}
\hline UF & $\stackrel{N}{\stackrel{N}{2}}$ & 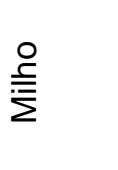 & 篣 & 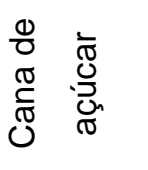 & $\frac{\pi}{\tilde{\infty}}$ & $\begin{array}{l}\frac{\pi}{0} \\
\frac{0}{0} \\
\frac{0}{0} \\
\Sigma\end{array}$ & $\begin{array}{l}\frac{10}{10} \\
\frac{10}{4} \\
\frac{0}{4}\end{array}$ & 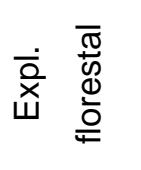 & 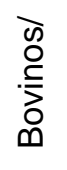 & 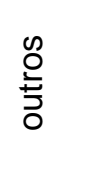 \\
\hline RO & 0,04 & 0 & 0 & 0 & 0 & 0 & 0 & 0 & & 0,23 \\
\hline Parte do NO* & 0,02 & 0 & 0 & 0,08 & 0 & 0 & 0 & 0 & & 0,86 \\
\hline PA-TO & 0,29 & 0,02 & 0 & 0,12 & 0,47 & $-0,01$ & 0 & 0,08 & & 1,42 \\
\hline MA-PI & 0,06 & 0 & 0 & 0,04 & 0,12 & $-0,01$ & 0 & 0,07 & & 0,11 \\
\hline PE-AL & 0 & 0 & 0 & $-0,09$ & 0 & 0 & 0 & 0 & & 0,30 \\
\hline BA & 0 & 0 & 0 & 0,03 & 0,15 & $-0,01$ & $-0,01$ & 0 & & 0,21 \\
\hline Parte do $\mathrm{NE}^{\star *}$ & 0 & 0 & 0 & $-0,01$ & 0 & 0 & 0 & 0 & & 0,53 \\
\hline MG & 0 & 0,12 & 0 & $-0,06$ & $-0,16$ & $-0,01$ & 0 & $-0,07$ & & 0,71 \\
\hline RJ-ES & 0,01 & 0 & 0 & $-0,03$ & 0 & $-0,01$ & 0 & 0 & & 0,26 \\
\hline SP & 0 & 0,10 & $-0,02$ & $-0,57$ & $-0,09$ & 0,03 & 0 & 0 & & 0,30 \\
\hline PR & 0 & $-0,15$ & $-0,04$ & 0,21 & 0,13 & 0 & 0 & 0 & & 0,24 \\
\hline SC-RS & $-0,21$ & $-0,27$ & $-0,02$ & 0 & 2,78 & 0,02 & 0 & $-0,05$ & & 1,17 \\
\hline MS & 0,01 & 0,07 & 0,02 & $-0,14$ & $-0,23$ & 0 & 0 & 0,02 & & 0,88 \\
\hline MT & 0,02 & 0 & 0 & 0,13 & $-0,08$ & 0,08 & 0 & $-0,02$ & & 1,32 \\
\hline GO-DF & 0,01 & 0,02 & 0 & 0,31 & $-2,07$ & 0 & 0 & $-0,06$ & & 6,14 \\
\hline
\end{tabular}

Fonte: Elaboração própria.

*Parte do NO: Acre; Amazonas; Roraima; e Amapá

** Parte do NE: Ceará; Rio Grande do Norte; Paraíba; Sergipe

*** Incluso outros cereais.

A base para simulação partiu da construção de um banco de dados histórico até o ano de 2015, o que impõe ao modelo o uso observado de variáveis agregadas macroeconômicas entre 2005-2015. A seguir, foram utilizadas as variáveis projetadas para o período de 2016 a 2030.

As variáveis relacionadas ao crescimento do PIB e População são exógenas, também consideradas pelo GLOBIOM-Brasil, conforme apresentado na Figura 19. Para o TERM-BR, a mudança temporal dessas variáveis causa impactos marginais no cenário macroeconômico de simulação. 


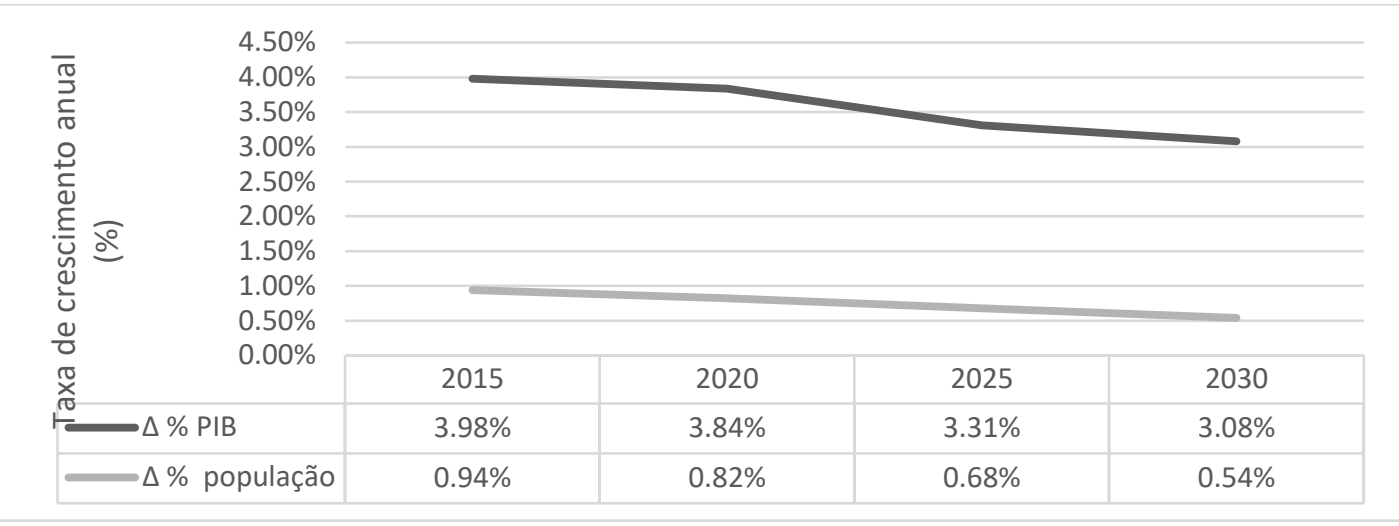

Figura 19. Projeção da taxa de crescimento anual (\%) do PIB e da população - Brasil (2015-2030) Fonte: Buurman et al. (2015). 


\section{RESULTADOS E DISCUSSÃO}

As simulações do modelo TERM-BR apresentam o impacto econômico para três cenários: i) CRA parcial; ii) sem CRA; e iii) Sem anistia. As informações desse cenários são confrontadas com as de um cenário base, que contempla todos esses mecanismos do Novo Código Florestal.

Os resultados podem ser comparados na variação do acumulado do período, ou ainda para o período selecionado, entre 2010 e 2030. A mudança no uso da terra, conforme base de dados, é observada a partir de 2020, quando passará a prevalecer todos os mecanismos do Novo Código Florestal. A princípio a discussão se passa em âmbito nacional e se finaliza em âmbito regional, sempre comparando os desvios dos três cenários de simulação em relação ao cenário base.

Como observado, os três cenários de simulação se baseiam em políticas de redução do desmatamento com o efeito da maior regeneração ambiental, havendo consequente redução da área produtiva. Essa redução da área permite uma mudança na estrutura agropecuária que difere em cada cenário, pois o território e os agentes envolvidos são distintos em cada simulação.

O mecanismo de cotas se mostra mais interessante aos produtores agrícolas, se comparado com os pecuaristas, os quais tem menor custo de oportunidade, uma vez que tenham condições de melhoria da produtividade total dos fatores $^{9}$. De qualquer modo, a área da pecuária no Brasil tende a ser cada vez mais pressionada pela exigência de recuperação de APP e RL imposta pelo Novo Código Florestal, além da pressão exercida para aumento da área de culturas, conforme alertaram Sparovek et al. (2011), Câmara et al. (2015) e Soterroni et al. (2016).

Os resultados no âmbito nacional indicam, conforme a Tabela 16, o desvio percentual para variáveis macroeconômicas selecionadas, em relação ao cenário base. Nota-se uma grande semelhança entre os impactos nos cenários 1 e 2 no âmbito nacional. Enquanto o impacto econômico no cenário 3 é maior, comparado aos anteriores. Esse último cenário é mais restrito do ponto de vista produtivo, principalmente por apresentar maior área regenerada (Ver seção 2.3.2).

\footnotetext{
${ }^{9}$ Ver Vieira Filho et al. (2005) e Vieira Filho (2017).
} 
Tabela 16. Desvio percentual, entre o cenário base em relação aos cenários 1,2 e 3, das variáveis macroeconômicas selecionadas, no acumulado do período 2010 - 2030

\begin{tabular}{l|r|r|r}
\hline Variáveis selecionadas & $\begin{array}{c}\text { Cenário 1 } \\
\text { CRA parcial } \\
\Delta \%\end{array}$ & $\begin{array}{c}\text { Cenário 2 } \\
\text { SEM CRA } \\
\Delta \%\end{array}$ & $\begin{array}{c}\text { Cenário 3 } \\
\text { SEM ANISTIA } \\
\Delta \%\end{array}$ \\
\hline Consumo & $-0,11$ & $-0,11$ & $-0,44$ \\
Emprego & 0,01 & 0 & 0,01 \\
Estoque de Capital & $-0,19$ & $-0,17$ & $-0,66$ \\
Exportação (Vol.) & 0,44 & 0,43 & 1,89 \\
Gastos Governo & $-0,09$ & $-0,11$ & $-0,45$ \\
Importação (Vol.) & $-0,13$ & $-0,14$ & $-0,4$ \\
Investimento real & $-0,79$ & $-0,84$ & $-3,09$ \\
PIB real & $-0,12$ & $-0,14$ & $-0,51$ \\
Salário real & $-0,27$ & $-0,28$ & $-1,15$ \\
\hline
\end{tabular}

Fonte: Elaboração própria.

O equilíbrio macroeconômico reestabelecido após a restrição no uso da terra se dá com a queda do PIB nos cenários (1,2 e 3) e, em longo prazo, haverá redução no salário real, de 0,27\%, 0,28\% e 1,15\%, nessa ordem. Essa redução afeta principalmente o Consumo das famílias, que por sua vez caiu em $0,11 \%$ ao desconsiderar total ou parcialmente o mecanismo de CRA. Ao desconsiderar a anistia das multas e sanções, o impacto no consumo nacional será quatro vezes maior, ou seja 0,44\% de queda. Os Gastos do Governo seguem a mesma tendência do consumo familiar, com queda de 0,09\%; 0,11\%; e 0,45\% nos cenários 1,2 e 3 , respectivamente.

Apesar disso, em nível nacional, a variável emprego não apresenta queda significativa, no acumulado do período entre 2010 e 2030, o que significa a absorção dos empregados por outros setores menos impactados. É fato que os setores afetados diretamente são intensivos em mão-de-obra, por isso será importante observar os valores desagregados regionalmente nesse quesito. Cabe lembrar que o modelo de equilíbrio geral leva em consideração o efeito substituição que pode ocorrer entre os fatores primários (terra, capital, trabalho), por meio da elasticidade de substituição. Assim, se a mão-de-obra for menos dispendiosa, também terá maior absorção. Outro fato importante é que a mão-de-obra pode se deslocar tanto entre regiões quanto entre setores, conforme o salário relativo.

Com relação ao estoque de capital, há maior queda comparado ao consumo, que resulta em redução, relativamente ao cenário base, de 0,19\% (CRA parcial); $0,17 \%$ (Sem CRA) e 0,66\% (Sem anistia). 
Apesar da redução do PIB, o volume de exportações se projeta acima da linha do cenário base. Em caso da não utilização das CRAs parcialmente ou totalmente, haverá redução da área produtiva para compensação de $R L$, mesmo assim as Exportações crescem em 0,44\% e 0,43\% para os respectivos cenários 1 e 2. Em caso de anistia, as exportações aumentam no acumulado do período analisado em $1,89 \%$. Isso se explica pela queda do consumo no mercado interno, fazendo com que haja variação nos termos de troca. $O$ impacto deprecia a taxa de câmbio, desvalorizando a moeda local, o que aumenta a vantagem comparativa do produto brasileiro no comércio internacional.

O investimento é a variável com maior queda nos três cenários. No caso de mudança na política ambiental conforme o primeiro e o segundo cenário (CRA parcial ou sem CRA), o investimento real acumulado entre 2010 e 2030 cai em 0,79\% e 0,84\%, respectivamente; no terceiro cenário (sem anistia), por sua vez, esse desvio mostra uma redução de 3,09\%. O resultado é consequência da redução de área produtiva e consequente redução do valor da produção dos setores.

Tais resultados vão ao encontro do estudo de Diniz (2012), conforme discutido anteriormente, na segunda seção, que ao restringir a variável terra, também houve aumento das exportações e queda no PIB, bem como nas demais variáveis.

Sem que haja a Cota de Reserva Ambiental para compensação de $R L$, 0 produtor se obriga a produzir em uma área restrita, embora ainda haja a possibilidade de desmatamento legal em outras áreas. Em outro cenário, ao desconsiderar a anistia aos proprietários com áreas consolidadas, há somente perda de área para recomposição ambiental dos passivos registrados antes de julho de 2008.

Ao desconsiderar o mecanismo de cota de reserva ambiental parcial/total ou a anistia, o PIB real acumulado se projeta abaixo da linha de base em todo o período. No entanto, no final do período (2030), nos cenários 1 e 2 o PIB real cai em $0,12 \%$ e $0,14 \%$, respectivamente, enquanto no terceiro cenário a queda chega $0,51 \%$. A retração é maior no terceiro cenário, com maior variação decrescente, uma vez que se trata do impacto do cenário com maior regeneração da vegetação nativa. Ainda assim, a queda não chega a $1 \%$ do valor acumulado na linha de base, ou seja, é uma pequena variação por se tratar de apenas mecanismos do Novo Código Florestal. Nisso, esse estudo se assemelha ao trabalho de Diniz (2012), que avaliou 
o impacto do Novo Código Florestal com relação ao Código anterior, quando obteve impactos inferiores a $1 \%$, (entre $0,17 \%$ e $0,19 \%$ no PIB com a Lei $12.651 / 2012$ ), conforme mencionado no capítulo 2.

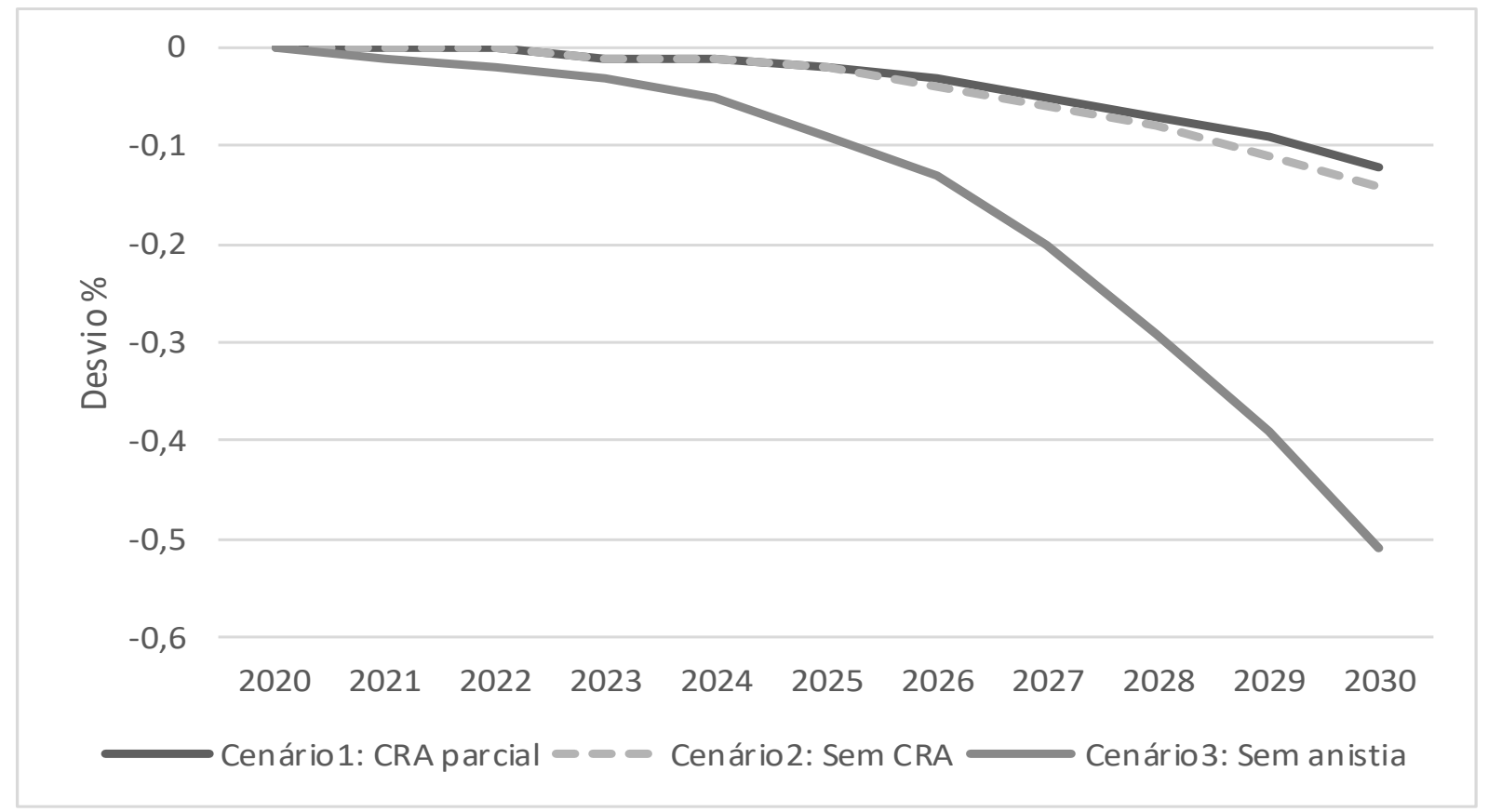

Figura 20. Desvio percentual do PIB real acumulado entre o cenário base em relação aos cenários sem CRA e sem anistia, em 2020 a 2030.

Fonte: Elaboração própria.

Assim como o PIB, a produção é afetada de modo distinto em cada setor econômico. Os produtos relacionados a agropecuária e agroindústria são mais impactados negativamente com a restrição de terra. A Tabela 17 apresenta o desvio percentual da produção total de produtos selecionados nos cenários 1, 2, 3, com relação à linha de base, para os produtos mais impactados negativamente (ver tabela completa no Apêndice D).

Conforme discutido na seção 2, o Brasil é um importante produtor de canade-açúcar, soja, e carnes, os quais estão entre os mais desfavorecidos com uma nova mudança na política ambiental. É fato que outros produtos elevaram sua produção, independente do cenário. Isso pode ocorrer em setores exportadores que se beneficiam com a desvalorização da moeda nacional. Logo, nas três simulações não ocorreram somente perdas. Cabe citar alguns produtos que obtiveram expressivas variações positivas em sua produção (Tabela 17): Arroz (cenário 3), exceto no Sul do Brasil; Soja Grão (cenários 1 e 2), exceto no Centro-Oeste), Café em grão no Norte do Brasil (cenários 1,2 e 3). 
Tabela 17. Desvio percentual da produção total das indústrias (produtos selecionados), por cenário e por grande região, Brasil, no acumulado do período 2010-2030.

\begin{tabular}{|c|c|c|c|c|c|c|c|c|c|}
\hline \multirow[b]{3}{*}{ Indústria } & \multicolumn{3}{|c|}{ Norte } & \multicolumn{3}{|c|}{ Nordeste } & \multicolumn{3}{|c|}{$\mathrm{SP}$} \\
\hline & \multicolumn{3}{|c|}{ Cenários } & \multicolumn{3}{|c|}{ Cenários } & \multicolumn{3}{|c|}{ Cenários } \\
\hline & $(1)$ & $(2)$ & (3) & $(1)$ & $(2)$ & (3) & $(1)$ & $(2)$ & $(3)$ \\
\hline 1 Arroz em casca & $-8,51$ & $-4,67$ & 62,12 & 1,87 & $-7,33$ & 3,48 & 0,31 & $-1,21$ & 0,05 \\
\hline 4 Cana-de-açúcar & $-19,16$ & 2,81 & 7,28 & $-0,97$ & 0,35 & $-1,08$ & 0,78 & $-1,07$ & $-3,74$ \\
\hline 5 Soja em grão & 1,17 & 2,41 & 2,92 & 3,19 & 4,5 & 3,04 & 2,53 & 6,83 & $-2,62$ \\
\hline 7 Mandioca & $-16,93$ & $-9,94$ & $-4,73$ & 1,6 & 5,14 & $-2,45$ & 56,5 & $-9,17$ & 48,35 \\
\hline 8 Fumo em Folha & 7,96 & 22,63 & $-6,65$ & $-3,06$ & $-3,05$ & $-1,09$ & $-0,32$ & $-0,25$ & 0,98 \\
\hline 11 Café em grão & 45,54 & 22,91 & 19,8 & $-1,63$ & $-2,11$ & $-0,74$ & $-0,31$ & $-0,27$ & $-0,47$ \\
\hline $\begin{array}{l}12 \text { Expl. Florestal e } \\
\text { Silvicultura }\end{array}$ & $-12,06$ & 11,64 & 14,15 & $-5,8$ & 7,45 & 5,03 & 1,95 & 0,45 & $-1,9$ \\
\hline $\begin{array}{l}13 \text { Bovinos e } \\
\text { Outros animais }\end{array}$ & $-5,26$ & $-1,17$ & $-1,2$ & 0,48 & 1,9 & 2,87 & 2,41 & $-0,46$ & $-2,63$ \\
\hline 14 Leite & $-4,85$ & 0,03 & $-0,66$ & $-0,23$ & 1,05 & 3,03 & 1 & $-1,18$ & $-2,33$ \\
\hline \multirow[t]{3}{*}{21 Refino de açúcar } & 4,05 & 3,48 & $-0,5$ & $-0,95$ & $-2,14$ & $-5,27$ & $-0,57$ & $-1,96$ & $-6,65$ \\
\hline & \multicolumn{3}{|c|}{ Restante do Sudeste } & \multicolumn{3}{|c|}{ Sul } & \multicolumn{3}{|c|}{ Centro-Oeste } \\
\hline & \multicolumn{3}{|c|}{ Cenários } & \multicolumn{3}{|c|}{ Cenários } & \multicolumn{3}{|c|}{ Cenários } \\
\hline Indústria & $(1)$ & $(2)$ & (3) & $(1)$ & $(2)$ & (3) & (1) & $(2)$ & (3) \\
\hline 1 Arroz em casca & 0,79 & 5,88 & 5,75 & $-0,14$ & 1,53 & $-12,1$ & $-0,22$ & 1,77 & 3,17 \\
\hline 4 Cana-de-açúcar & $-0,77$ & 0,3 & 1,73 & $-1,38$ & $-0,27$ & 10,77 & $-0,56$ & 2,82 & 3,12 \\
\hline 5 Soja em grão & 7,04 & 12,72 & $-0,14$ & 1,08 & 7,45 & 5,13 & $-9,21$ & $-13,9$ & 10,31 \\
\hline 7 Mandioca & 5,17 & 5,49 & $-7,96$ & 8,75 & $-15,7$ & 5,61 & $-23,1$ & 3,75 & 6,64 \\
\hline 8 Fumo em Folha & 0,2 & $-0,15$ & 0,64 & 0,05 & 0,28 & 1,51 & $-0,01$ & 0,53 & 1,14 \\
\hline 11 Café em grão & $-0,61$ & $-0,46$ & $-0,64$ & $-0,39$ & $-0,28$ & $-0,52$ & $-0,82$ & 0,33 & $-1,03$ \\
\hline $\begin{array}{l}12 \text { Expl. Florestal e } \\
\text { Silvicultura }\end{array}$ & 1,47 & $-1,76$ & $-4,5$ & 0,02 & $-0,45$ & $-2,16$ & 2,91 & $-13,5$ & $-4,73$ \\
\hline $\begin{array}{l}13 \text { Bovinos e } \\
\text { Outros animais }\end{array}$ & 2,4 & 1,89 & $-5,58$ & 2,49 & $-8,43$ & $-14,6$ & $-1,95$ & $-5,82$ & 16,89 \\
\hline 14 Leite & 1,31 & 1,53 & $-4,69$ & 1,49 & $-8,74$ & $-13,8$ & 4,68 & $-4,57$ & 37,37 \\
\hline 21 Refino de açúcar & 0,15 & $-0,16$ & $-2,96$ & 0,03 & $-2,67$ & $-6,81$ & $-0,5$ & $-0,67$ & $-7,13$ \\
\hline
\end{tabular}

Fonte: Elaboração própria.

No cenário 1, ao considerar o mercado de CRA parcialmente, é importante notar os produtos com maiores quedas em sua produção, como ocorreu com Mandioca, que retraiu em 23,1\% no Centro Oeste, região que foi responsável por cerca de $5 \%$ da produção brasileira desse produto, em 2015. Essa commoditie colocou o Brasil em terceiro lugar no ranking de produção mundial (em 2016), ficando atrás apenas da Nigéria e Thailândia, conforme apresentado na seção 3. No Norte, a maior queda ocorre na produção de Cana-de-açúcar, com retração de $19,16 \%$. Com essa queda, além do efeito negativo no emprego e renda, também haverá queda do volume de exportações. Nessa região a produção de Mandioca também é afetada, em 16,93\%. No Nordeste, a queda da produção foi menor, em 
relação às regiões anteriores. A Exploração florestal nordestina retraiu 5,8\%. O Sudeste e o Sul foram as regiões menos impactadas, pela simulação do Cenário 1, onde as maiores quedas, respectivamente, foram registradas na produção de Milho e Cana-de-açúcar. A Figura 21 ilustra a essa configuração entre os três produtos com maior queda na produção, por grandes regiões, para esse cenário 1 .

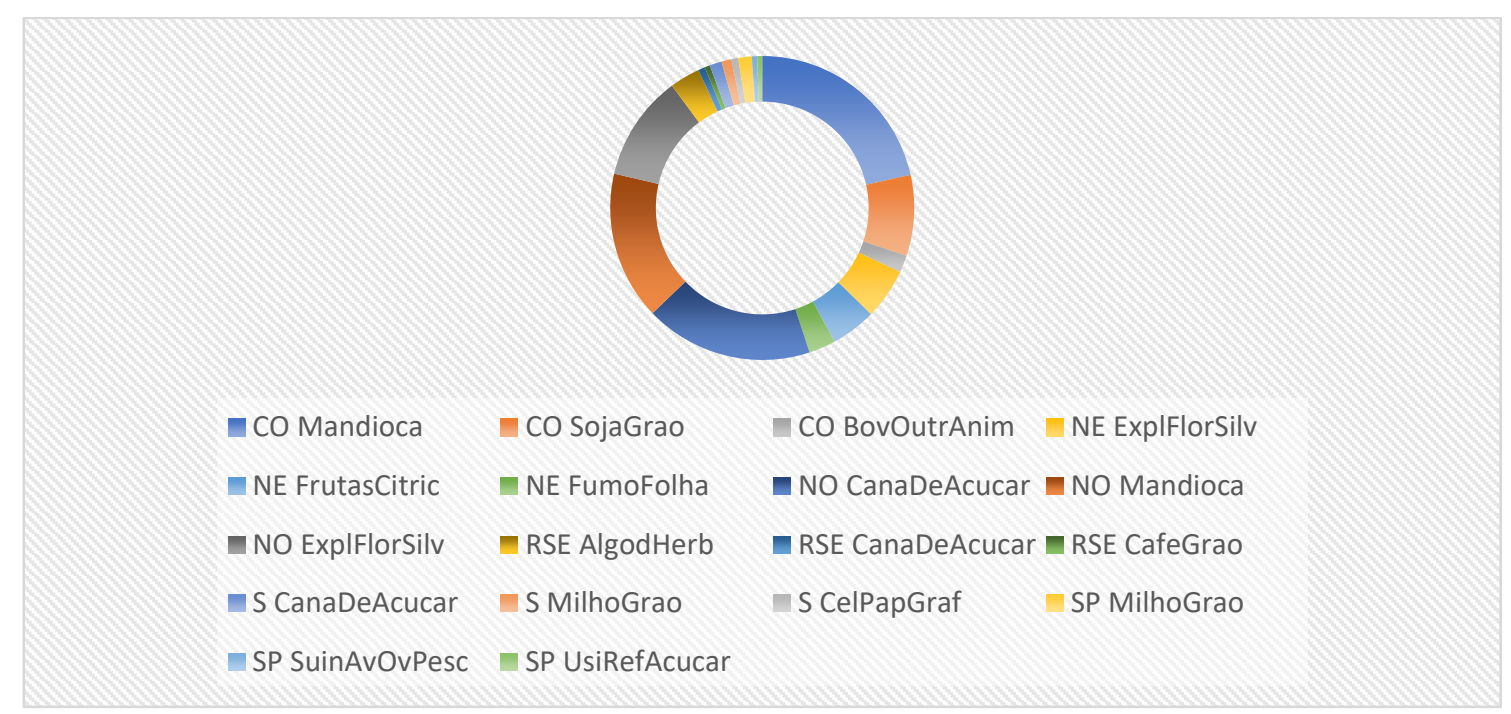

Figura 21. Redução percentual da Produção total das indústrias por grande região, cenário 1 (CRA parcial), Brasil, 2010-2030

Fonte: Elaboração própria.

Os resultados para o Cenário 2 não se assemelham aos do primeiro Cenário. No cenário 2, ao desconsiderar totalmente o mecanismo de compensação de RL por meio do mercado de CRA, a produção mais afetada negativamente é a da Mandioca nas regiões Sul, com queda de15,7\%; Centro-Oeste, com a queda de 15,66\%; Norte com queda de 9,94\%; em SP, com queda de 9,17\%. Já na região Nordeste a maior perda se deu na produção de Arroz, 7,33\%. Em seguida, com Fumo em Folha, que registrou queda de 3,05\%. O impacto desse Cenário é mais brando, em relação ao anterior, à Exploração Florestal no Restante do Sudeste, onde sua produção cai em 1,76\%. No Restante do Sudeste, as restrições desse cenário geraram pequenas variações na produção agropecuária. A Figura 22 ilustra a essa configuração entre os três produtos com maior queda na produção, por grandes regiões, para esse cenário 2 .

Como discutido na seção 3.3 , as restrições impostas afetam de modo diferente cada região. Uma região com uso intensivo da terra tende à maiores perdas econômicas. Isso pode afetar, principalmente, a agricultura num nível 
microrregional, em região que tem esse meio como único setor dinâmico da sua economia.

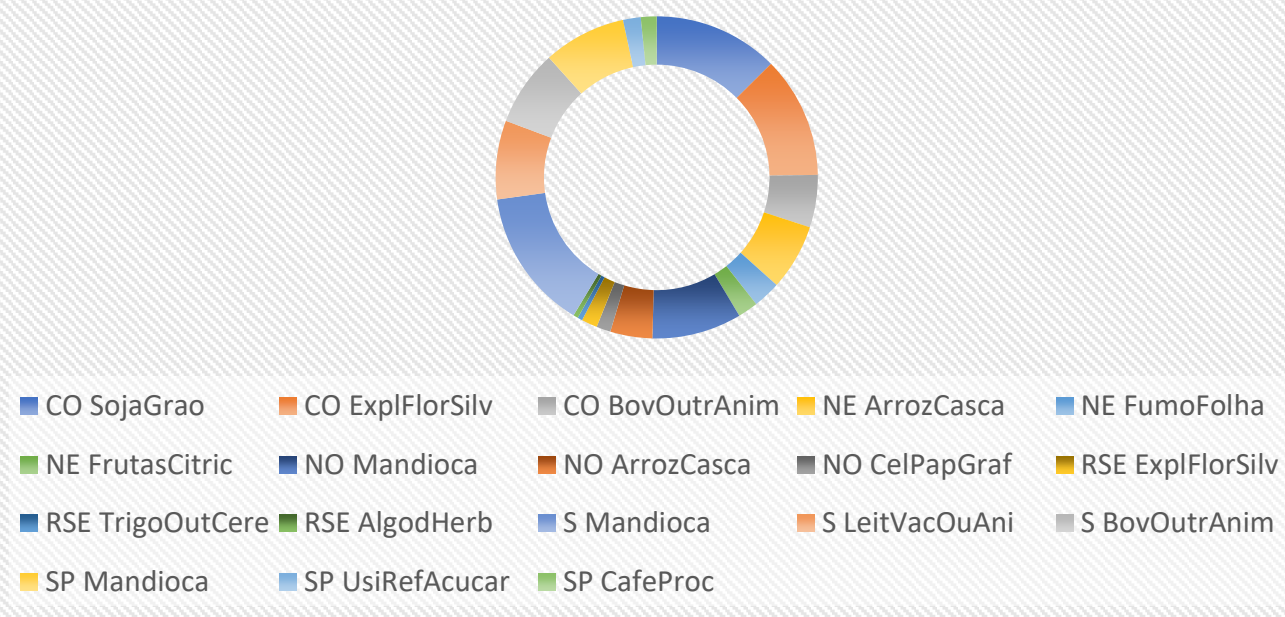

Figura 22. Redução percentual da Produção total das indústrias por grande região, cenário 2 (Sem CRA), Brasil, 2010-2030

Fonte: Elaboração própria.

No cenário 3, ao desconsiderar a anistia, as maiores quedas de produção foram registradas em produtos diferentes dos cenários anteriores. Houve um maior impacto na produção de Leite, que chegou a uma queda de $37,37 \%$ na região Centro-Oeste. A produção de Bovinos e outros animais é impactada fortemente no Centro-Oeste, no Sul e no RSE, caindo 16,89\%, 14,58\%, 5,58\%, respectivamente. Essa queda não foi compensada em outras regiões. Portanto, esse se mostra como o pior cenário para pecuaristas, independentemente da região. Ver Figura 23.

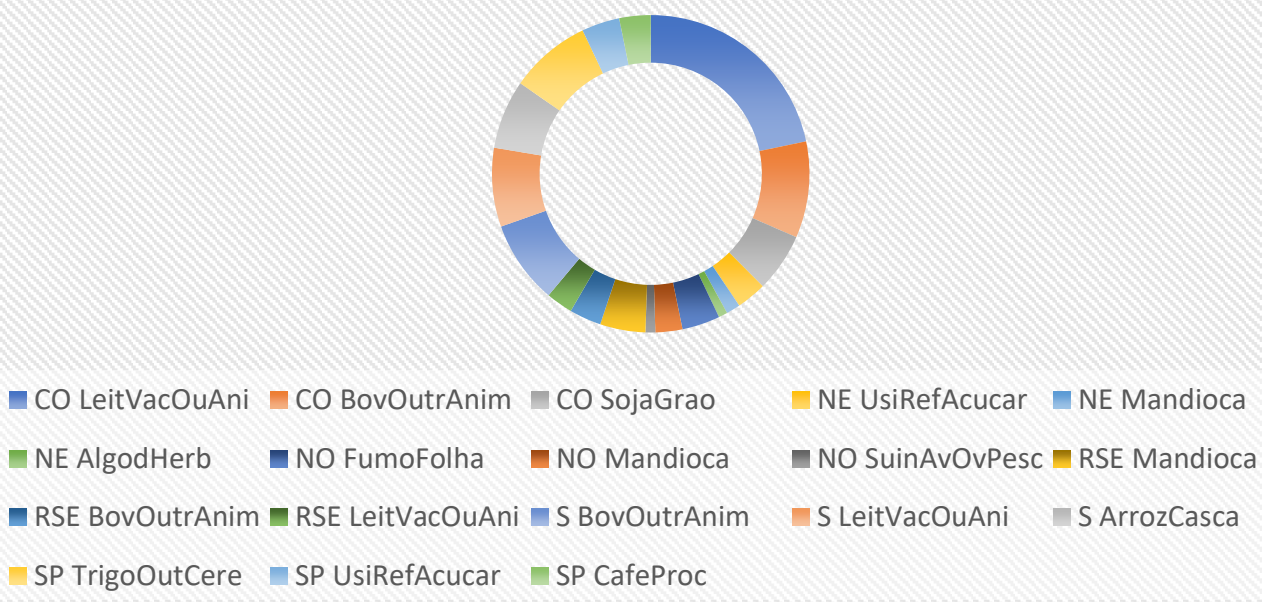

Figura 23. Redução percentual da Produção total das indústrias por grande região, cenário 3 (Sem anistia), Brasil, 2010-2030

Fonte: Elaboração própria. 
Ainda nesse terceiro cenário, em SP, houve expressiva queda na produção de Trigo e outros cereais, $14,26 \%$. Os produtos da agropecuária sofrem pequenas variações nas regiões Norte e Nordeste. A Figura 23 ilustra a essa configuração entre os três produtos com maior queda na produção, por grandes regiões, para esse cenário 3.

Nota-se a correlação entre os setores mais afetados pelas restrições impostas e sua importância socioeconômica na agropecuária, conforme ressaltado no capítulo 2, dentre esses estão os setores relacionados à (ao): Cana-de-Açúcar; Milho; Algodão; entre outras. A Tabela 18 apresenta as três indústrias com maior impacto negativo no emprego, nos três cenários de simulação, por grande região.

Tabela 18. Desvio percentual na demanda por trabalho das indústrias (com maiores quedas), por grande região e por cenário, Brasil, no acumulado do período 2010-2030.

\begin{tabular}{|c|c|c|c|c|c|c|}
\hline \multirow[t]{2}{*}{ Região } & \multicolumn{2}{|c|}{ Cenário 1} & \multicolumn{2}{|c|}{ Cenário 2} & \multicolumn{2}{|c|}{ Cenário 3} \\
\hline & Indústria & $\begin{array}{c}\text { Emprego } \\
(\Delta \%)\end{array}$ & Indústria & $\begin{array}{c}\text { Emprego } \\
(\Delta \%)\end{array}$ & Indústria & $\begin{array}{c}\text { Emprego } \\
(\Delta \%)\end{array}$ \\
\hline $\mathrm{CO}$ & Mandioca & $-14,19$ & $\begin{array}{l}\text { Exploração } \\
\text { Florestal }\end{array}$ & $-11,79$ & Leite & $-24,7$ \\
\hline $\mathrm{CO}$ & Soja em Grão & $-6,18$ & Soja em Grão & $-9,35$ & Refino de Açúcar & $-8,23$ \\
\hline $\mathrm{CO}$ & $\begin{array}{l}\text { Trigo e outros } \\
\text { cereais }\end{array}$ & $-1,85$ & Leite & $-2,66$ & Óleos & $-7,67$ \\
\hline NE & Frutas Cítricas & $-3,66$ & Arroz & $-7,12$ & Refino de Açúcar & $-7,34$ \\
\hline NE & Fumo em folha & $-2,75$ & Refino de Açúcar & $-2,92$ & Mandioca & $-3,56$ \\
\hline NE & $\begin{array}{l}\text { Exploração } \\
\text { Florestal }\end{array}$ & $-2,43$ & Fumo em folha & $-2,6$ & Algodão & $-1,33$ \\
\hline NO & Cana-De-Açúcar & $-16,26$ & Arroz & $-2,97$ & Mandioca & $-6,25$ \\
\hline NO & Mandioca & $-8,49$ & Mandioca & $-2,78$ & Fumo em folha & $-5,62$ \\
\hline NO & $\begin{array}{l}\text { Exploração } \\
\text { Florestal }\end{array}$ & $-8,16$ & Papel e Celulose & $-2,23$ & Álcool & $-2,38$ \\
\hline RSE & Algodão & $-3,33$ & $\begin{array}{l}\text { Exploração } \\
\text { Florestal }\end{array}$ & $-3,92$ & Mandioca & $-7,46$ \\
\hline RSE & Cana-De-Açúcar & $-0,77$ & Milho em Grão & $-0,93$ & $\begin{array}{l}\text { Exploração } \\
\text { Florestal }\end{array}$ & $-6,37$ \\
\hline RSE & Café em grão & $-0,6$ & Algodão & $-0,92$ & Refino de Açúcar & $-3,29$ \\
\hline$S$ & Cana-De-Açúcar & $-1,45$ & Mandioca & $-7,39$ & Arroz & $-10,52$ \\
\hline$S$ & Papel e Celulose & $-0,86$ & Leite & $-5,95$ & Refino de Açúcar & $-8,85$ \\
\hline$S$ & Milho em Grão & $-0,73$ & $\begin{array}{l}\text { Bovinos e Outros } \\
\text { animais }\end{array}$ & $-5,32$ & Milho em Grão & $-8,74$ \\
\hline SP & Milho em Grão & $-1,23$ & Mandioca & $-5,34$ & $\begin{array}{l}\text { Trigo e outros } \\
\text { cereais }\end{array}$ & $-13,05$ \\
\hline SP & Refino de Açúcar & $-0,73$ & Refino de Açúcar & $-2,64$ & Refino de Açúcar & $-9,1$ \\
\hline SP & Café Processado & $-0,67$ & Café Processado & $-2,21$ & Café Processado & $-6,95$ \\
\hline
\end{tabular}

Fonte: Elaboração própria. 
Regionalmente, a variável emprego segue a estrutura de produção dos setores. Apesar dessa variável apontar o pleno emprego em nível nacional, ao final do período analisado, os resultados regionais mostram que a demanda por emprego diminuiu principalmente nos setores agropecuários que apresentaram queda em sua produção.

Como mostra a (Tabela 18), quedas maiores que $10 \%$ na demanda por emprego ocorreram nas regiões: Centro-Oeste, para a produção de Mandioca, Expl. Florestal, e Leite (cenários 1,2 e 3, respectivamente); no Norte com a indústria da Cana-De-Açúcar (cenário 1); no estado de São Paulo houve uma queda acentuada na demanda por emprego na indústria de Trigo e outros cereais (cenário 3); e no Sul houve queda para a produção de Arroz (cenário3).

As consequências das restrições no uso da terra seriam amenizadas com ganhos de produtividade. No entanto, algumas regiões também enfrentam maiores dificuldades nesse sentido, conforme detalha o Apêndice $E$. A região Norte foi a que mais sofreu perda de produtividade da terra, em diversos produtos da lavoura. Cabe destacar os estados de Parte do NO (Cana-de-açúcar) e Rondônia (Café Grão), no cenário 1; Parte do NO (Cana-de-açúcar e Café Grão) e Minas gerais (Soja Grão) também perdeu produtividade no cenário 2; e no cenário 3 as maiores perdas de produtividade da terra ocorreram em Pará Tocantins (Cana-de-açúcar) e SC-RS (Soja Grão).

Em contrapartida, alguns estados apresentaram ganho na produtividade da terra (Apêndice E). Vale destacar, no cenário 1, Pará Tocantins (Cana-de-açúcar e Soja Grão). No cenário 2, os maiores ganhos de produtividade da terra ocorreram nos estados de: Mato Grosso do Sul (Cana-de-açúcar) e Pará e Tocantins (Soja Grão). No cenário3, cabe destacar: Mato Grosso do Sul (Cana-de-açúcar); Goiás e DF (Soja Grão).

Conforme os resultados macroeconômicos regionais, nota-se o impacto das políticas em cada unidade da federação. A Figura 24 apresenta a variação do PIB real, por UF, no acumulado entre 2010 e 2030, entre os resultados das políticas simuladas e da linha de base.

Os resultados desta pesquisa mostram que, no âmbito nacional, o perdão das sanções causa maior impacto negativo no PIB real da economia em relação ao mecanismo de cotas de reserva ambiental, como discutido anteriormente. Ressaltese que regionalmente, tais mudanças na legislação têm menor impacto sobre 
estados que possuem grandes áreas com ativo ambiental. As regiões com biomas que apresentam grandes déficit de reserva legal e APP, consequentemente necessitarão de apoio para amenizar as suas perdas econômicas relacionadas à redução de área produtiva. Esse é um grande desafio, sem entrar em questões relacionadas às desigualdades já existentes no meio rural. Enquanto, os mais diversos produtores agrícolas sofrerão impactos no primeiro e no segundo cenário (CRA parcial e sem CRA), as regiões onde há numerosas pequenas propriedades, normalmente concentradas no Nordeste e no Sul do país, são provavelmente os maiores impactados conforme aponta a simulação no terceiro cenário (sem anistia), embora interferência no PIB regional seja influenciado pelo valor agregado da produção das grandes culturas, como a soja, cana-de-açúcar, por exemplo.

Assim, conforme Figura 24, a maioria dos estados nacionais apresentaram perdas econômicas com as três simulações, embora, os estados de Rondônia, Amazonas, Parte do Norte, Pará-Tocantins, Maranhão-Piauí e Parte do NE contrariem essa tendência, em pelo menos um dos cenários. Minas Gerais se mostrou indiferente nas duas primeiras simulações. Enquanto os estados com maior perda econômica, que reflete no PIB nacional, foram: PA-TO (-2,5\%), no cenário 1; Mato Grosso (-4,5\%) no cenário 2; e Goiás e DF (-4,3\%).

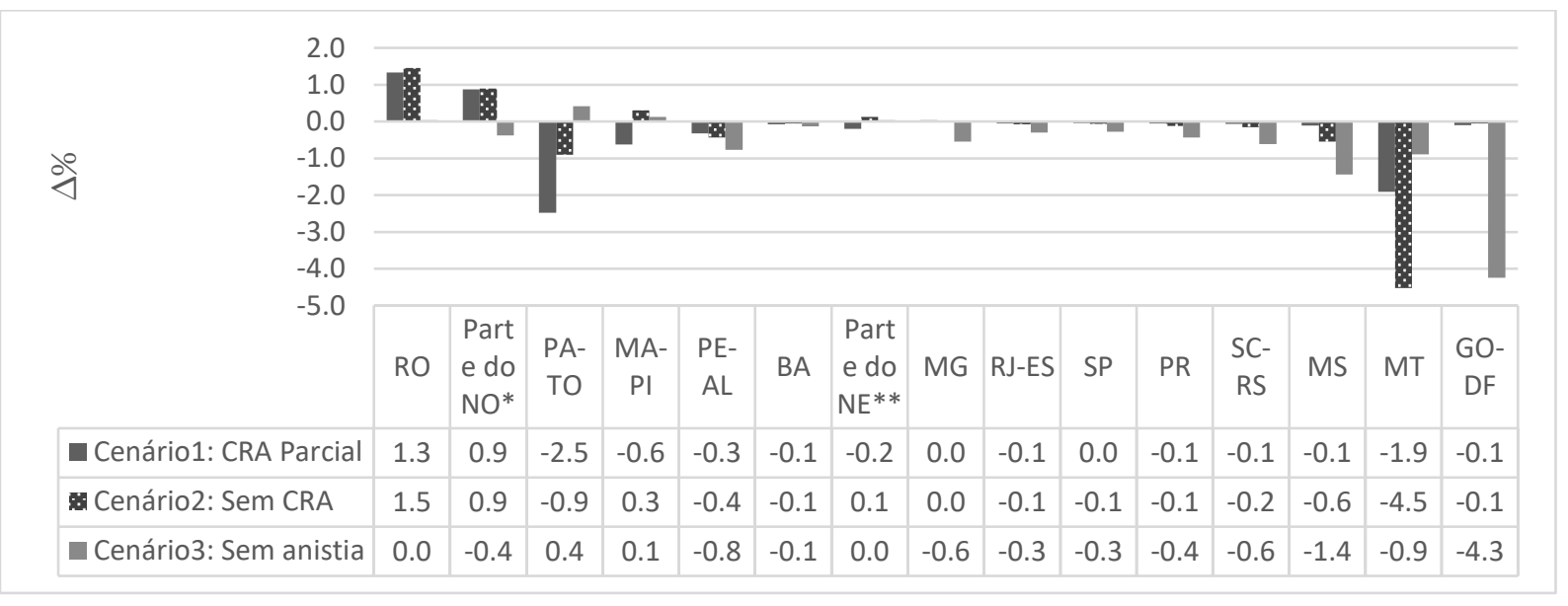

Figura 24. Desvio percentual do PIB real, por UF, nos cenários 1, 2 e 3, relativo ao cenário base, no acumulado período entre 2010-2030.

Fonte: Elaboração própria.

*Parte do NO: Acre; Amazonas; Roraima; e Amapá

** Parte do NE: Ceará; Rio Grande do Norte; Paraíba; Sergipe

Sem a política de cotas, Pará-Tocantins e Mato Grosso foram os que mais perderam área destinada ao cultivo da soja. Os mesmos estados também sofrem 
com grande perda da área de pastagem. Assim, o PIB é afetado drasticamente nessas regiões.

Entretanto, não havendo anistia, a economia regional é mais afetada em Goiás (incluindo DF), em Mato Grosso do Sul e Mato Grosso, devido à grande perda de área de pastagem nessas regiões. A situação de GO-DF é agravada pela perda, também, de área para o cultivo da soja, sem grandes compensações com outros produtos da lavoura. $\mathrm{O}$ que ocorre com os estados menos afetados economicamente é a mudança na estrutura produtiva dentro da agropecuária, principalmente no Sul e no Nordeste, que apesar das perdas, também obtiveram variações positivas nas grandes culturas como soja e cana-de-açúcar.

A variável consumo reflete a contração econômica, influenciada pela redução dos salários reais e mudança na estrutura regional do emprego. O consumo das famílias, como os gastos do governo, regional segue a tendência do PIB regional, conforme ilustra a Figura 25

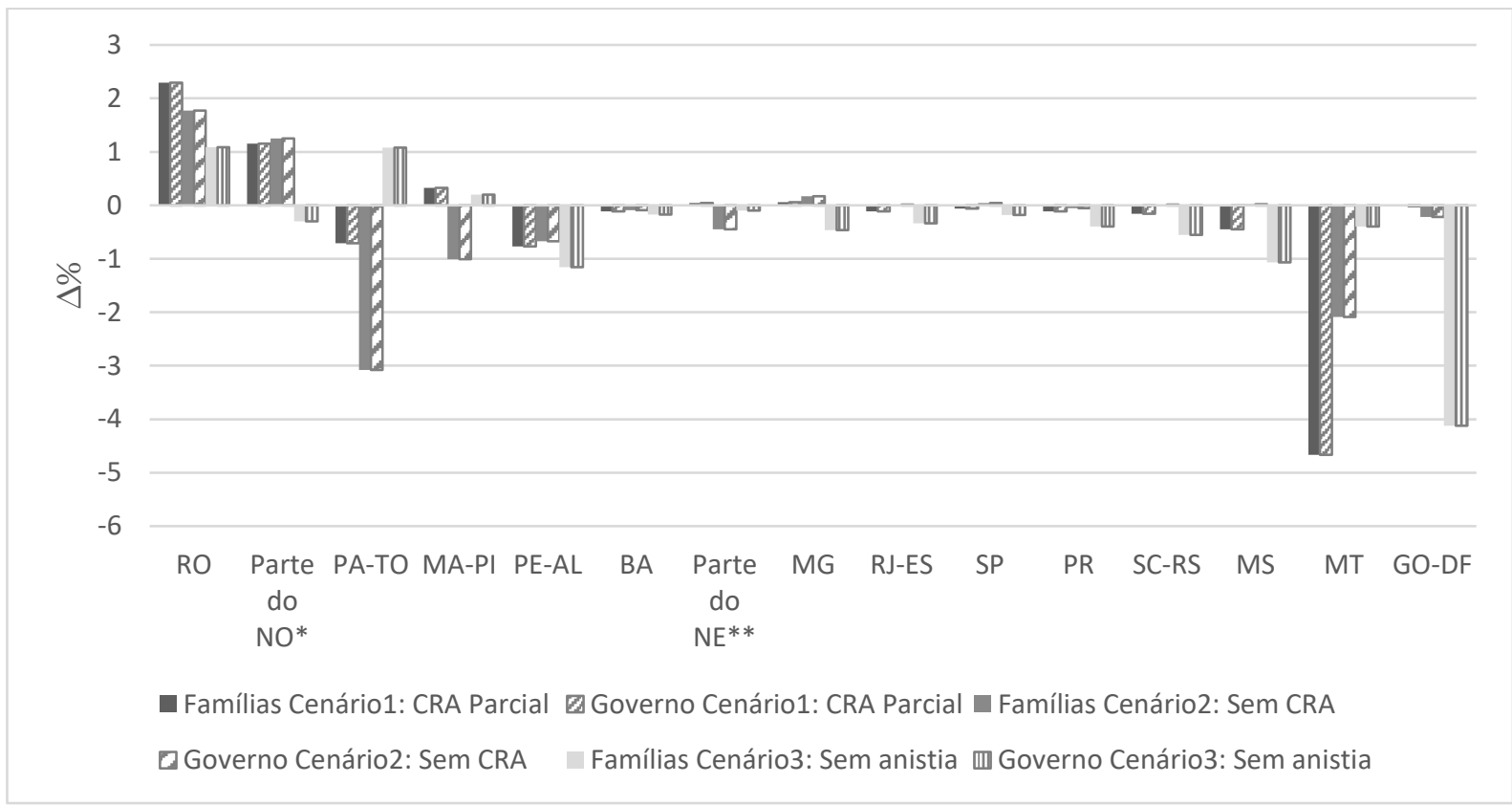

Figura 25. Desvio percentual do Consumo real nos cenários 1,2 e 3, relativo ao cenário base, no acumulado período entre 2010-2030.

Fonte: Elaboração própria.

*Parte do NO: Acre; Amazonas; Roraima; e Amapá

** Parte do NE: Ceará; Rio Grande do Norte; Paraíba; Sergipe

O investimento é um importante variável para verificar a situação econômica de uma região. A Figura 26 apresenta a configuração do investimento entre os estados brasileiros. Os estados que apresentaram maiores quedas nessa variável, também já foram destacados anteriormente pela perda em seu produto interno bruto: 
PA-TO (-5,9\%), no cenário 1; Mato Grosso (-9,7\%) no cenário 2; e Goiás e DF ($12 \%)$.

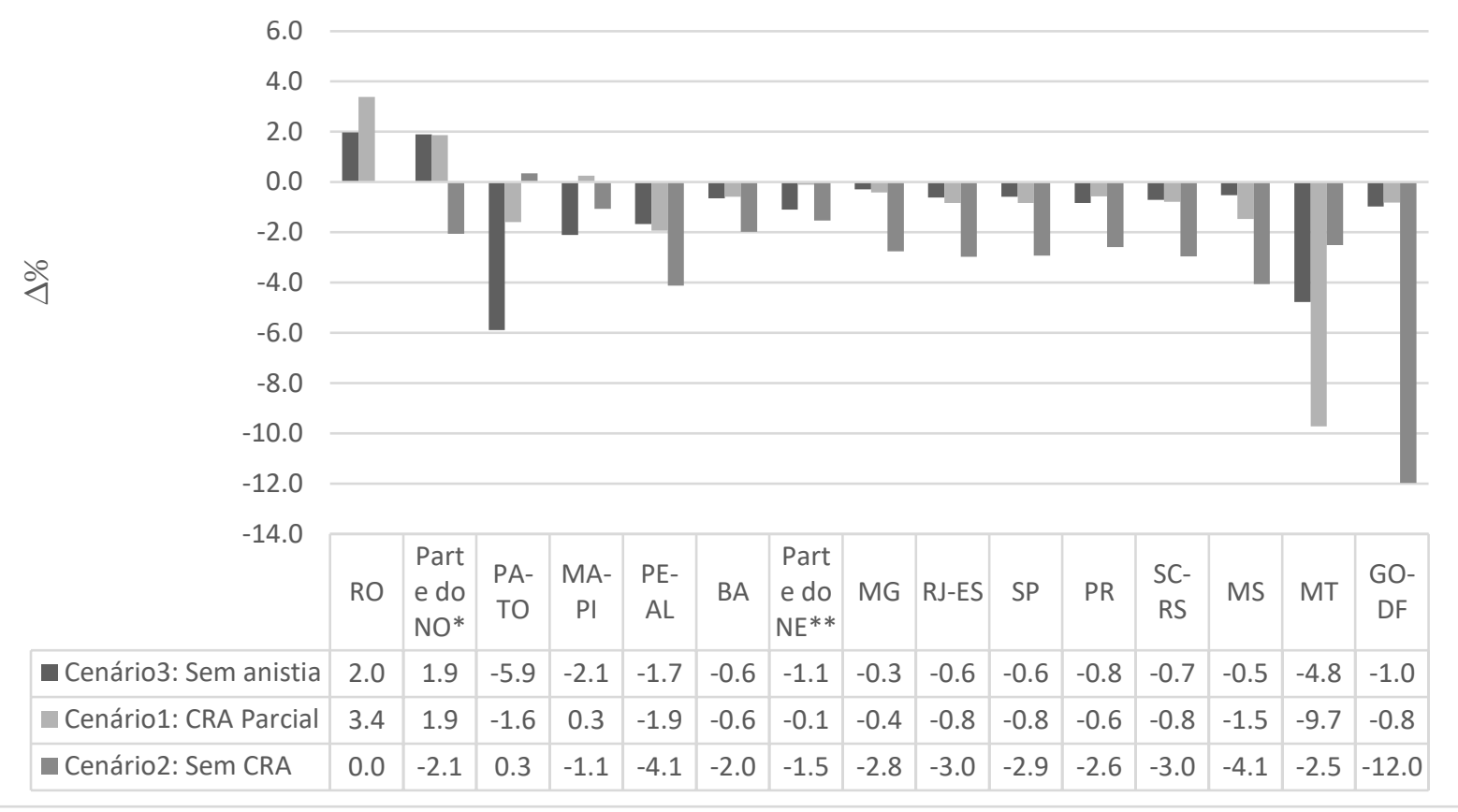

Figura 26. Desvio percentual do Investimento real nos cenários 1, 2 e 3, relativo ao cenário base, no acumulado período entre 2010-2030.

Fonte: Elaboração própria.

*Parte do NO: Acre; Amazonas; Roraima; e Amapá

** Parte do NE: Ceará; Rio Grande do Norte; Paraíba; Sergipe

Conforme mencionado anteriormente, as exportações apresentam uma configuração diferente das variáveis anteriores. Os maiores acréscimos em volume de exportações que ocorreram em cada cenário foram em: GO-DF no primeiro $(1,3 \%)$ e terceiro cenário $(7,6 \%)$ e na BA no segundo cenário $(0,8 \%)$ (Figura 27$)$.

As restrições impostas pelas políticas ambientais pressionam os setores agroexportadores para a comercialização no mercado externo. Porém alguns estados reduziram o seu volume de produtos exportados: MT no primeiro $(-2,7 \%)$ e no segundo cenário (-14,5\%); e em RO no terceiro cenário (-8,9\%) (Figura 27). 


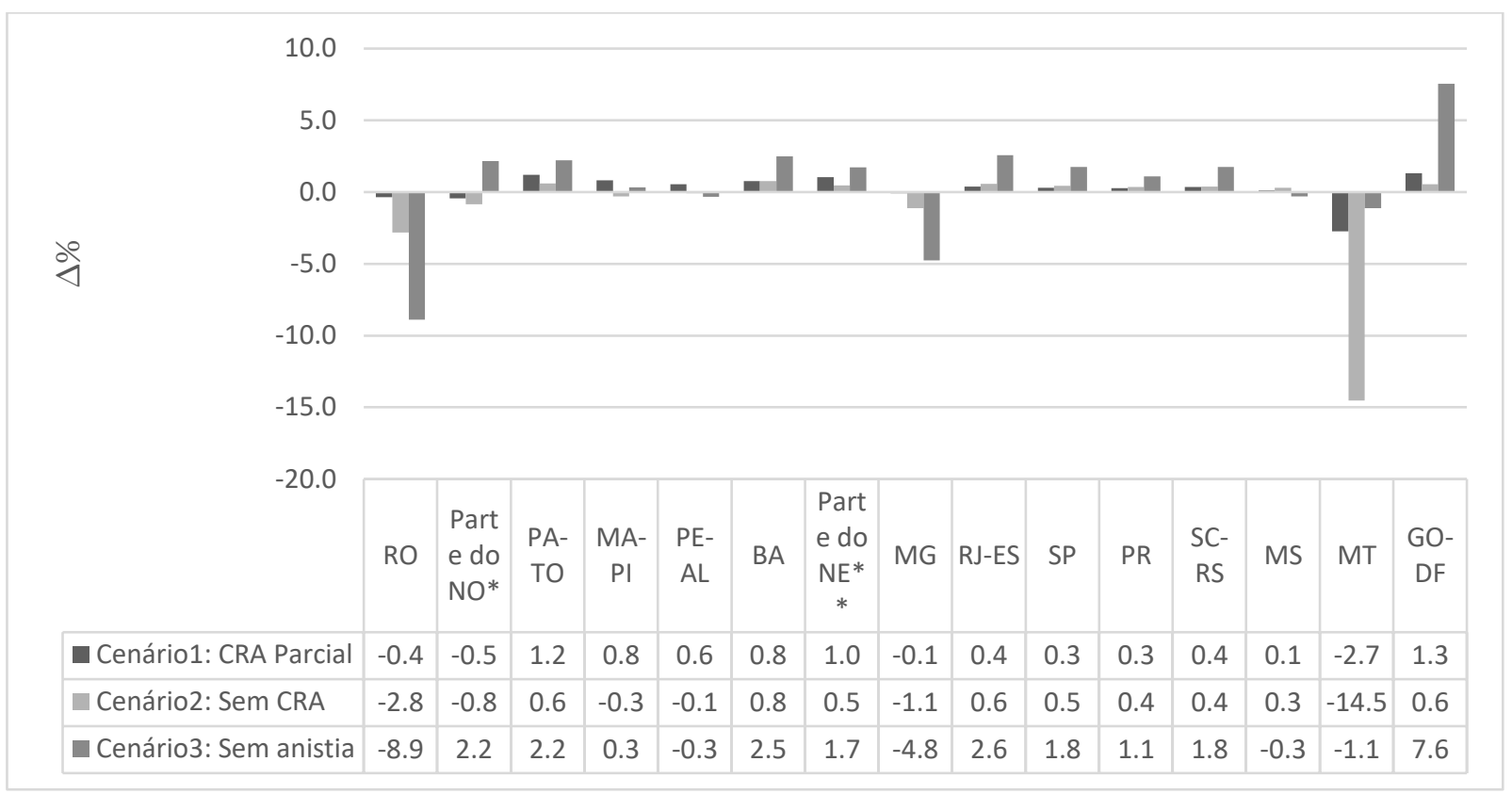

Figura 27. Desvio percentual do Exportações nos cenários 1, 2 e 3, relativo ao cenário base, no acumulado período entre 2010-2030.

Fonte: Elaboração própria.

*Parte do NO: Acre; Amazonas; Roraima; e Amapá

** Parte do NE: Ceará; Rio Grande do Norte; Paraíba; Sergipe

A esse respeito, são relevantes as sugestões de Brancalion (2016) e Soares Filho (2014), que ressaltam a necessidade de uma criação de políticas aos pequenos proprietários para que haja maior aderência às exigências do Novo Código Florestal. Reis et al. (2015) reforçam a necessidade de se verificar impactos sociais pontuais. Tais políticas ambientais seriam mais eficientes se tratadas de modo regional, como se pode perceber ao observar as diferentes necessidades entre regiões, embora represente grande avanço em termos de implementação.

Em suma, nesse debate, essa pesquisa se insere para testar os impactos que causariam novas mudanças no Novo Código Florestal. Os resultados macroeconômicos, gerados a partir do modelo TERM-BR, apontaram uma contração no PIB da economia inferior a $1 \%$. Esse impacto não deve gerar grandes preocupações no âmbito econômico nacional, ao passo que essa contração se deve à substituição de área produtiva por área de recomposição ambiental. Esse resultado vai ao encontro de outros estudos, citados na revisão de literatura destapesquisa (seção 2), que apresentaram impactos econômicos brandos ao considerar redução total ou parcial no desmatamento. 


\section{CONCLUSÕES}

O Novo Código Florestal tem gerado um dos maiores debates no âmbito legislativo brasileiro, uma vez que se discutem democraticamente direitos antagônicos. Ainda em 2018, estão sendo julgados dispositivos específicos da Lei 12.651, conforme as Ações Diretas de Inconstitucionalidades (ADIs ns 4.901, 4.902, 4.903 e 4.937).

As mudanças na legislação ambiental aprovadas em 2012 visavam os principais pilares do desenvolvimento sustentável, os quais estão nos âmbitos ambiental, econômico e social. Os instrumentos criados com essa legislação são considerados inovadores por diversos pesquisadores, por conciliar principalmente a economia e o meio ambiente e trazer formas diferentes para reparação da degradação ambiental. É possível destacar as CRAs, nesse sentido. O mercado de CRA além de permitir a compensação de RL, promove a valorização dos ativos ambientais. O PRA é outro instrumento importante para regularização das propriedades rurais com áreas consolidadas.

Cabe salientar a realidade do produtor rural no Brasil, onde há extrema desigualdade socioeconômica rural. Dos 5,8 milhões de imóveis rurais de propriedade particular, $90 \%$ são consideradas pequenas propriedades, com até quatro módulos fiscais. Dessas, a grande maioria apresenta déficits em APP e/ou RL que, conforme o decreto de julho de 2008, incorreriam em ações administrativas e penais afetando ainda mais a sustentabilidade econômica dessas propriedades, com a redução de área produtiva. Tais consequências foram levantadas em debates, assim como também o questionamento sobre a aderência à essa legislação ambiental, uma vez que o país carece de fiscalização. Como resultado, houve a aprovação do Novo Código, o qual legaliza por diversos instrumentos a compensação desses déficits.

Novas mudanças no Novo Código Florestal, conforme exigem as ADls, trariam novos desafios ao produtor rural. As ADls promovem um novo debate jurídico em torno dos instrumentos da legislação aprovada, mas que pode trazer um retrocesso econômico ao meio rural. São diversos os artigos questionados, entretanto essa pesquisa se atém aos principais, conforme foram testados nas simulações dos três cenários hipotéticos. 
O Cenário 1, que apresentou uma simulação de impactos econômicos em caso da utilização parcial de CRA para compensação de RL, se baseou na hipótese de que seria mais vantajoso aos pecuaristas recompor seus déficits em sua própria propriedade, enquanto os agricultores compensariam seus déficits no mercado de CRA. Os resultados dessa simulação apontam impactos pequenos em nível nacional, embora apontem impactos maiores aos produtores do Centro-Oeste, do Norte e Nordeste. Nesse cenário, foram expressivas as quedas produtivas de Mandioca, Cana-de-açúcar e Exploração Florestal e Silvicultura. Esse impacto é sentido ao longo do período analisado, de modo que há substituição de culturas, conforme as tendências explicitadas na revisão dessa pesquisa. Nesse sentido, a Soja ganha espaço devido ao seu preço relativo.

O Cenário 2, desconsidera totalmente o mercado de CRA. Essa hipótese baseia-se na possibilidade desse instrumento ser julgado inconstitucional pelo STF. Além disso, a ausência de regulamentação das CRAs pode dificultar sua implementação, pela insegurança jurídica. Existe ainda, o questionamento sobre a efetividade das negociações na BVRio e quanto aos preços que devam compensar o custo de oportunidade da terra, pois em alguns biomas, o mercado desses títulos pode ser pouco atrativo ou inviabilizado.

Assim, os resultados desse segundo cenário se mostram bastante diferentes do anterior, pois agora não são somente pecuaristas perdem solo produtivo, mas agricultores também. O impacto em nível nacional é pequeno, embora seja maior em relação ao primeiro cenário. A queda na produção de Mandioca afeta negativamente a economia do Sul, Centro-Oeste e Norte de forma mais intensa.

O Cenário 3 envolve uma simulação com grandes possibilidades de ocorrência, pois as ADIs ainda estão sendo julgadas. O ministro relator do STF votou contra a anistia das multas e sanções administrativas e penais, que beneficiava àqueles autuados pela lei de crimes ambientais, desde que os mesmos regularizassem seus imóveis rurais. Faltam, ainda nove votos para o encerramento do processo. Essa decisão envolve, principalmente, a grande maioria dos imóveis com até quatro módulos fiscais, cujos proprietários possuem grande tendência à não adesão do processo de regularização. Uma vez que, a devida implementação do Código Florestal depende da iniciativa dos proprietários e posseiros rurais. Cabe salientar, que essa era uma grande dificuldade nos termos do Código Florestal de 1965. 
Caso não haja anistia das multas, a preocupação recai sobre os estados do Centro-Oeste. A redução na área produtiva traz impactos econômicos negativos, ainda mais fortes no terceiro cenário, comparado aos dois primeiros, principalmente, nos setores da agropecuária e indústria alimentícia. A produção cai, pois há uma redução na fronteira de produção e, em consequência, haverá no período uma realocação dos fatores produtivos.

Regionalmente e setorialmente a restrição de uso da terra imposta traz uma mudança na estrutura produtiva no setor agropecuário. Há uma tendência natural para substituição de produtos da lavoura, conforme os seus preços relativos. Os resultados apresentaram uma variação da produção positiva, da soja, por exemplo, em pelo menos dois dos cenários de simulação, em todas as grandes regiões, exceto Centro-Oeste.

Tais impactos setoriais e regionais nos três cenários são importantes para a compreensão dos resultados macroeconômicos desagregados por unidade da federação. É fato que cada setor de atividade tem sua própria importância econômica, sendo que em algumas regiões há um único setor dinâmico. Grandes culturas como soja, milho e cana-de-açúcar possuem uma importante participação no PIB nacional e nas exportações de modo que também tem grande influencia nos resultados dessa pesquisa.

Apesar da contração econômica, na maioria dos estados, seriam brandos os impactos das alterações das políticas ambientais no que se refere às taxas de variações no emprego, devido a absorção de outros setores e em outros estados, conforme a possibilidade de mobilidade da mão-de-obra, ao longo do período 2010 2030.

Do ponto de vista ambiental, sob a hipótese do primeiro cenário, em que não se possa utilizar o mercado de CRA, é possível que aqueles produtores com ativo ambiental sejam desestimulados à mantê-lo, podendo legalmente desmatar áreas para cultivo. Há um questionamento quanto à adesão dos produtores rurais ao cumprimento dessa lei aprovada em 2012, cabe salientar que o Novo Código Florestal está sendo implementado, como reflete ao número de produtores cadastrados no CAR. Caso haja novas mudanças, também haverá maiores atrasos nessa implementação.

As informações do mecanismo de Cadastro Ambiental Rural (CAR) indicam ampla adesão do produtor rural. Isso é um fato que reforça a aprovação dos 
proprietários e posseiros rurais, o que significa um importante passo para efetividade da legislação ambiental. Apesar das dúvidas sobre a legitimidade ambiental na proteção do meio ambiente, ela amplia a sustentabilidade econômica, principalmente aos pequenos agricultores.

Embora essa pesquisa apresente brandas perdas econômicas, cabe uma sugestão de políticas compensatórias, principalmente aos estados com maiores perdas e que já apresentem outros problemas conforme indicadores socioeconômicos.

O custo socioeconômico de qualquer uma das principais mudanças no Novo Código Florestal seria em prol de um ganho ambiental, com vistas a necessidade de se garantir a preservação do ecossistema para mitigação de gases de efeito estufa e de mudanças climáticas. Essas mudanças trariam, também, ganhos em termos diplomáticos pelo fato de o Brasil sustentar um perfil ambiental que o capacite a uma boa posição negociadora nos fóruns que debatem o tema. Porém, deve-se ter cautela com as regiões e, principalmente com os setores econômicos mais afetados. 


\section{REFERÊNCIAS}

ARAUJO, S. M. V. G. de; GANEM, R. S. A nova lei florestal e a questão urbana. In: SILVA, A.P.M.; MARQUES, H.R.; SAMBUICHI, R.H.R. (Org.) Mudanças no código florestal brasileiro: desafios para a implementação da nova lei. Rio de Janeiro: Ipea, 2016. 359. p.

ASSAD, E. D.; et al. Changes in soil carbon stocks in Brazil due to land use: paired site comparisons and a regional pasture soils survey. Biogeosciences. 2013

AZEVEDO, A. et al. Produção de commodities no Brasil: desmatamento zero e ilegalidade zero. Manaus: IPAAM, 2015. Disponível em <http://www.ipam.org. br/download/livro/Producao-de-commodities-no-Brasil/762>. acesso em 04 set. 2017.

BANCO MUNDIAL. Estudo de Baixo Carbono para o Brasil. 2010. Disponível em <http://siteresources.worldbank.org/BRAZILINPOREXTN/Resources/38171661276778791019/UsoTerra_Final_Portugue.pdf> acesso em 04 set. 2017.

BERNASCONI, P. Custo-efetividade ecológica da compensação de reserva legal entre propriedades no estado de São Paulo. Brasília: SF̧B, Esaf, 2015. 72 p. Disponível em <http://www.esaf.fazenda.gov.br/assuntos/premios/premios-1/ipremio-florestal-brasileiro/3olugar-010p.pdf/view>. acesso em20 mar. 2017.

BRANCALION, P. H. S.; et al. A critical analysis of the Native Vegetation Protection Law of Brazil (2012): updates and ongoing initiatives. Brazilian Journal of Nature Conservation, v. 14, p. $1-15$, abr. 2016. Disponível em < http://www.sciencedirect.com/science/article/pii/S1679007316300020>. acesso em 14 jul. 2016.

BRASIL - Decreto n. 23.793 de 23 de janeiro de 1934 - Aprova o Código Florestal. Diário Official da União. Rio de Janeiro, RJ, 21 mar. 1935.

. Lei n. 4.771 de 15 de setembro de1965 - Institui o novo Código Florestal. Diário Oficial [da] República Federativa do Brasil, Brasília, DF, 3 jan. 1967.

. Lei n. 9.605, de 12 de fevereiro de 1998. Dispõe sobre as sanções penais e administrativas derivadas de condutas e atividades lesivas ao meio ambiente, e dá outras providências. Legislação Federal. Sítio eletrônico internet - 27 Disponível em < http://www.planalto.gov.br/CCivil_03/leis/L9605.htm> Acesso em 14 jul. 2017.

. Decreto Federal ํo 6.514, de 22 de julho de 2008. Dispõe sobre as infrações e sanções administrativas ao meio ambiente, estabelece o processo administrativo federal para apuração destas infrações, e dá outras providências. Diário Oficial [da] República Federativa do Brasil, Brasília, DF, (2008 jul.).

. Lei Federal № 9.985, de 18 de julho de 2000. Regulamenta o art. 225, § 10, incisos I, II, III e VII da Constituição Federal, institui o Sistema Nacional de Unidades de Conservação da Natureza e dá outras providências. Diário Oficial [da] República Federativa do Brasil Disponível em<http://www.mma.gov.br/port/conama/legiabre.cfm?codlegi=322> acesso em out. 2017. 
. Lei n. 12.651 de 25 de maio de 2012. Dispõe sobre a proteção da

vegetação nativa; altera as Leis n. 6.938, de 31 de agosto de 1981, 9.393, de 19 de dezembro de 1996, e 11.428, de 22 de dezembro de 2006; revoga as Leis n. 4.771, de 15 de setembro de 1965, e 7.754, de 14 de abril de 1989, e a Medida Provisória n. 2.166-67, de 24 de agosto de 2001; e dá outras providências. Diário Oficial [da] República Federativa do Brasil, Brasília, DF, 25 mai. 2012.

Lei n. 13.295 de 14 de junho de 2016. Altera a Lei n. 12.096, de 24 de novembro de 2009, a Lei n. 12.844, de 19 de julho de 2013, a Lei n. 12.651, de 25 de maio de 2012, e a Lei n. 10.177, de 12 de janeiro de 2001. Diário Oficial [da] República Federativa do Brasil, Brasília, DF, 14 jun. 2016.

MEDIDA PROVISÓRIA No 2.166-67, DE 24 DE AGOSTO DE 2001. Altera os arts. 10, 4o, 14, 16 e 44, e acresce dispositivos à Lei no 4.771, de 15 de setembro de 1965, que institui o Código Florestal, bem como altera o art. 10 da Lei no 9.393, de 19 de dezembro de 1996, que dispõe sobre o Imposto sobre a Propriedade Territorial Rural - ITR, e dá outras providências. Diário Oficial [da] República Federativa do Brasil Brasília, DF, 2001.Disponível em <http://www.planalto.gov.br/ccivil_03/mpv/2166-67impressao.htm> acesso em 14 jul. 2017.

BUURMAN, M.; et al. Description of the GLOBIOM-BRAZIL database available in the REDD-PAC WFS server. Project under the International Climate Initiative of the Federal Ministry for the Environment, Nature Conservation and Nuclear Safety (BMU), Germany. Brasil, REDD-PAC, 2015. Disponível em <http://www.reddpac.org/reports/wfs_globiom_brazil_1April2015.pdf>. acesso em 02 dez. 2017.

CÂMARA, G.; et al.. Modelling Land Use Changes in Brazil. Project under the International Climate Initiative of the Federal Ministry for the Environment, Nature Conservation and Nuclear Safety (BMU), Germany. Brasil, REDD-PAC, 2015. Disponível em < http://www.redd-

pac.org/reports/D2.2.2_Techical_Description_ModelCluster_Brazil.pdf>. acesso em 20 abr. 2017.

CARVALHO, T. S.; DOMINGUES, E. P. Projeção de um cenário econômico e de desmatamento para a Amazônia Legal brasileira entre 2006 e 2030.Nova econ., Belo Horizonte, v. 26, n. 2, p. 585-621, Aug. 2016. Available from <http://www.scielo.br/scielo.php?script=sci_arttext\&pid=S0103$63512016000200585 \& \operatorname{lng}=\mathrm{en} \& \mathrm{nrm}=\mathrm{iso}>$. access

on 24 Jan. 2018. http://dx.doi.org/10.1590/0103-6351/2665.

CHIAVARI, J.; LOPES, C. L. Novo Código Florestal. Parte I: decifrando o novo Código Florestal. Projeto Iniciativa para o Uso da Terra (Input). Rio de Janeiro: CPI, 2015.

DINIZ, T. B. Impactos socioeconômicos do Código Florestal Brasileiro: uma discussão à luz de um modelo computável de equilíbrio geral. 2012. $112 \mathrm{f}$. Dissertação (Mestrado) - Escola Superior de Agricultura "Luiz de Queiroz", Piracicaba, 2012. 
DINIZ, T.; FERREIRA FILHO, J. B. S. Impactos Econômicos do Código Florestal Brasileiro: uma discussão à luz de um modelo computável de equilíbrio geral. Rev. Econ. Sociol. Rural, Brasília, v. 53, n. 2, p. 229-250, June 2015. Disponível em $<$ http://www.scielo.br/scielo.php?script=sci_arttext\&pid=S0103-

20032015000200229\&lng=en\&nrm=iso>. accesso em 23 Jan. 2018.

DIXON, P. B.; RIMMER, M. (2002). Dynamic general equilibrium modelling for forecasting and policy: A practical guide and documentation of MONASH. Handbook of microsimulation modelling, Amsterdan, Elsevier, v. 256, 2001.

FACHINELLO, A. L. Avaliação do impacto econômico de possíveis surtos da gripe aviária no Brasil: uma análise de equilíbrio geral computável. 2008. Tese (Doutorado em Economia Aplicada) - Escola Superior de Agricultura Luiz de Queiroz, Universidade de São Paulo, Piracicaba, 2008. doi:10.11606/T.11.2008.tde17072008-150109. acesso em 24 jan. 2018.

FACHINELLO, A. L.; FERREIRA FILHO, J. B. S. Gripe aviária no Brasil: uma análise econômica de equilíbrio geral.Rev. Econ. Sociol. Rural, Brasília, v. 48, n. 3, p. 539566, Set. 2010. Disponível em $<$ http://www.scielo.br/scielo.php?script=sci_arttext\&pid=S0103$20032010000300003 \&$ Ing=en\&nrm=iso > . acesso em 25 nov. 2017.

FAO. Faostat - Statistics Database 2010, 2013. Disponível em <http://www.faostat.fao.org/faostat>. acesso em 7 ago. 2017.

FERREIRA FILHO, J. B. S. et al. Tax reform, income distribution and poverty in Brazil: A general equilibrium analysis. MPIA Working Paper 2007-26, Poverty and Economic Policy Research Network - PEP-NET, Québec, 2007.

FERREIRA FILHO, J. B. S.; HORRIDGE, M. J. Climate change impacts on agricultural andi nternal migrations in Brazil. In: 13th Annual Conferenceon Global Economic Analysis, Penang, Malaysia, 2010.

. Economic Integration, Poverty and Regional Inequality in Brazil. Revista Brasileira de Economia, v. 60, p. 363-387, 2006b.

Endogenous land use and supply, and food security in Brazil. In: ANNUAL CONFERENCE ON GLOBAL ECONOMIC ANALYSIS, 15, 2012, Genebra, Suíça. Conference Papers... Center for Global Trade Analysis, Purdue University, 2012. Disponível em: <https://www.gtap.agecon.pudue.edu/resources/res_display.asp?RecordID=3814>. acesso em 04 set. 2017.

. The Doha Development Agenda and Brazil: Distributional Impacts. Review of Agricultural Economics, v. 28, p. 362, $2006 a$.

Would world agricultural trade liberalization help the poor of Brazil? In: 11th Annual Conference on Global Economic Analysis, Helsinki, Finland, 2008.

Climate change impacts on agriculture and internal migrations in Brazil. In: 14th Annual Conference on Global Economic Analysis, 2011, Venice Proceedings of the 14th Annual Conference on Global Economic Analysis, 2011. 
. Ethanol expansion and indirect land use change in Brazil. Land Use

Policy, Amsterdam, v. 36, p. 595-604, 2014.

FERREIRA FILHO, J.B.S.; RIBERA, L.; HORRIDGE, M. Deforestation Control and Agricultural Supply in Brazil. American Journal of Agricultural Economics, Oxford, v. 97, p. 589-601, 2015.

FREITAS, F. L. M. de; SPAROVEK, G.; MATSUMOTO, M. A adicionalidade do mecanismo de compensação de reserva legal da lei no 12.651/2012: uma análise da oferta e demanda de cotas de reserva ambiental. In: SILVA, A.P.M.; MARQUES, H.R.; SAMBUICHI, R.H.R. (Org.) Mudanças no código florestal brasileiro: desafios para a implementação da nova lei. Rio de Janeiro: Ipea, 2016. 359. p.

HORRIDGE, J.M.; MADDEN J.R.; WITTWER, G. The Impact of the 2002-03 Drought on Australia. Journal of Policy Modeling 27 (3): 285-308. 2005.

HORRIDGE, M. The TERM model and its data base. Working General. Paper No. G-219 July 2011. Cops/Impact: Centre of Policy Studies, Monash University, 2011. Disponível em:<https://www.copsmodels.com/ftp/workpapr/g-219.pdf>. acesso em 4 fev. 2017.

IBGE. Biomas Brasileiros. Disponível em < https://cnae.ibge.gov.br/en/component/content/article/94-7a12/7a12-vamosconhecer-o-brasil/nosso-territorio/1465-ecossistemas.html?/temid=6160\#mataatlantica > acesso em 20abr. 2018.

\section{Desflorestamento na Amazônia Legal e nos biomas extra}

amazônicos. Disponível em: <https://sidra.ibge.gov.br/pesquisa/ids/tabelas> acesso em 13 dez. 2017b.

Diretoria de Pesquisas, Coordenação de Contas Nacionais, e Coordenação de População e Indicadores Sociais. Dados da população disponíveis em: < http://www.estatgeo.ibge.gov.br/EstatGeo2016/mapa/index.html?metodo=3\&qtdfaixa $\mathrm{s}=5$ \&anomalha $=2009 \&$ cor8=undefined \&cor $7=$ undefined \&cor $6=$ undefined $\& \operatorname{cor} 5=\% 23$ e76594\&cor4=\%23ef70a5\&cor3=\%23f796bd\&cor2=\%23ffb2ce\&cor1=\%23ffcfe7\&faix ade $1=$ undefined\&faixade $2=$ undefined\&faixade $3=$ undefined\&faixade $4=$ undefined\&faix ade $5=$ undefined\&faixade $6=$ undefined\&faixade $7=$ undefined\&faixade $8=$ undefined\&faix aate $1=$ undefined\&faixaate $2=$ undefined\&faixaate $3=$ undefined\&faixaate $4=$ undefined $\& f$ aixaate $5=$ undefined\&faixaate $6=$ undefined\&faixaate $7=$ undefined\&faixaate $8=$ undefine $\mathrm{d} \&$ nom $=$ undefined\&con=undefined\&ent=undefined\&urldados=http://api.sidra.ibge.go v.br/values/t/1194/n3/all/v/2363/p/2013/f/u\&fontetabelaagregada=Produto\%20Interno \%20Bruto\%20per\%20capita\#>. acesso em 12 jan. 2018.

Mapa da Cobertura e Uso da Terra. 2010. Disponível em: < ftp://geoftp.ibge.gov.br/informacoes_ambientais/cobertura_e_uso_da_terra/uso_atual/ mapas/brasil/uso_da_terra_2010.pdf > acesso em $13 \mathrm{dez} \overline{2} 0 \overline{1} 7 \mathrm{a}$.

Países: Brasil Meio Ambiente. Disponível em:

<http://paises.ibge.gov.br/\#/pt/pais/brasil/info/meio-ambiente> acesso em 04 jan 2016a. 
Sistema IBGE de Recuperação Automática (SIDRA). Disponível em:

<http://www.sidra.ibge.gov.br/bda/tabela/listabl.asp?z=p\&o=8\&i=P\&c=780> acesso em 13 jan. 2016c.

INCRA. SISTEMA NACIONAL DE CADASTRO RURAL - SNCR. Disponível em:< http://www.incra.gov.br/sites/default/files/uploads/estrutura-fundiaria/estat-sticas-deim-veis-rurais-/brasil_cadastro_imoveis_rurais_geral_pub_e_priv.pdf> acesso em 05 dez. 2016.

INPE. Taxas anuais de desmatamento na Amazônia Legal Brasileira (AMZ). 1988-2017. Disponível em:< http://www.obt.inpe.br/prodes/dashboard/prodesrates.html > acesso em 12 dez. 2017.

IPAM. Cotas de Reserva Ambiental (CRA) para a conservação e o desenvolvimento sustentável: informações básicas para tomadores de decisão nos Estados. Brasília (DF): Instituto de Pesquisa Ambiental da Amazônia - IPAM, 2015.

LANDAU, E. C. et al. Variação geográfica do tamanho dos módulos fiscais no Brasil. Sete Lagoas: Embrapa Milho e Sorgo, 2012.199 p. ISSN 1518-4277; 146).

MACHADO, L. de A. O cadastro ambiental rural e as cotas de reserva ambiental no novo código florestal: uma análise de aspectos legais essenciais para a sua implementação in: SILVA, Ana Paula Moreira da; MARQUES, Henrique Rodrigues; SAMBUICHI, Regina Helena Rosa (Org.). Mudanças no código florestal brasileiro: desafios para a implementação da nova lei. Rio de Janeiro: Ipea, 2016.

MINISTÉRIO DO MEIO AMBIENTE. Biomas. Disponível em: <http://www.mma.gov.br/biomas> acesso em 20 abr. 2018.

. Código Florestal. Disponível em:

<http://www.mma.gov.br/port/conama/processos/2C87C7CF/SeminAPPConamaMaJ oselntrodCodFlor.pdf> acesso em 26 fev. 2016.

MIRANDA, E. E. de; CARVALHO, C. A. de; OSHIRO, O. T.; MARTINHO, P. R. R. Agricultura e Preservação Ambiental no Brasil: Primeira Análise do Cadastro Ambiental Rural. Disponível em: <https://www.cnpm.embrapa.br/projetos/car/>. Acesso em: 20 fev. 2018.

PAVAO, A. R.; FERREIRA FILHO, J. B. S. Impactos econômicos da introdução do milho Bt11 no Brasil: uma abordagem de equilíbrio geral inter-regional. Rev. Econ. Sociol. Rural, Brasília, v. 49, n. 1, p. 81-108, Mar. 2011. Available from $<$ http://www.scielo.br/scielo.php?script=sci_arttext\&pid=S0103-

$20032011000100004 \& \operatorname{lng}=$ en\&nrm $=$ iso $>$. access on 24 Jan. 2018. http://dx.doi.org/10.1590/S0103-20032011000100004.

PEARSON, K. Automating the Computation of Solutions of large Economic Models. 1988. Economic Modelling, 7:385-395. 
REDD-PAC. Description of the GLOBIOM-BRAZIL database available in the REDD-PAC WFS server. Project under the International Climate Initiative of the Federal Ministry for the Environment, Nature Conservation and Nuclear Safety (BMU), Germany. Brasil, 2015. Disponível em: <http://www.reddpac.org/reports/wfs_globiom_brazil_1April2015.pdf> acesso em 02 dez. 2015.

REDD-PAC Data Sets: Biomes. Disponível em: <http://www.redd-

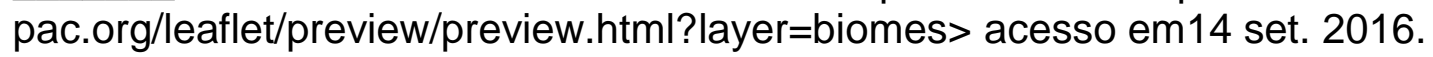

REIS, L. C. et al.. Código Florestal brasileiro: impactos econômicos e sociais no município de Bandeirantes - PR. Eng. Agríc., Jaboticabal, v. 35, n. 4, p. 778-788, Ago. 2015. Disponível em:

$<$ http://www.scielo.br/scielo.php?script=sci_arttext\&pid=S010069162015000400778\&lng=en\&nrm=iso> acesso em 30 Nov. 2016.

SANTOS, J. A. dos. Impactos na economia brasileira, pela substituição dos combustíveis fósseis por etanol e biodiesel, no período de 2010 a 2030. 2013. 110f. Tese (Doutorado em Economia Aplicada) - Escola Superior de Agricultura "Luiz de Queiroz", Universidade de São Paulo, Piracicaba.

SCARAMUZZA, C. A. de M. et al. Elaboração da proposta do plano nacional de recuperação da vegetação nativa, in: SILVA, Ana Paula Moreira da; MARQUES, Henrique Rodrigues; SAMBUICHI, Regina Helena Rosa (Org.). Mudanças no código florestal brasileiro: desafios para a implementação da nova lei. Rio de Janeiro: Ipea, 2016.

SCHNEIDER; Uwe A.; McCARL, Bruce A.; SCHMID, Erwin. "Agricultural Sector Analysis on Greenhouse Gas Mitigation in US Agriculture and Forestry." 2007. Agricultural Systems 94 (2): 128-40.

SERVIÇO FLORESTAL BRASILEIRO. Cadastro ambiental rural: boletim informativo. Brasília: SFB, 2016. Disponível em:

$<$ http://www.florestal.gov.br/cadastro-ambiental-rural/numeros-do-cadastroambiental-rural> acesso em 13 abr. 2017.

Cadastro ambiental rural: boletim informativo. Brasília: SFB, 2017. Disponível em: < http://www.florestal.gov.br/documentos/car/boletim-do-car/3231boletim-informativo-dezembro-de-2017/file > acesso em 13 jan. 2018.

SILVA, A. P. M. da; MARQUES, H. R.; SAMBUICHI, R. H. R. (Org.). Mudanças no código florestal brasileiro: desafios para a implementação da nova lei. Rio de Janeiro: Ipea, 2016.

SOARES FILHO, B. S. et al. Cracking Brazil's forest Code. Science, v. 344, p. 363364, 2014.

SOTERRONI, A.C. et al. Modelagem de Mudanças de Uso da Terra no Brasil. In: VIEIRA FILHO, J. E. et al. (Org.). Agricultura, Transformação produtiva e Sustentabilidade. Brasília: Ipea, 2016. 391 p.

SOUZA, C. S. AS (IN) JUSTIÇAS AMBIENTAIS na Legislação Brasileira. Revista Formação (Online), v. 3, n. 23, p. 127-142, mai./ago. 2016. 
SOUZA, G. S. et al. Substituição de culturas: uma abordagem empírica envolvendo cana-de-açúcar, soja, carne bovina e milho. Revista de Política Agrícola, Brasília, ano 16, n. 2, pag. 5-13, abr./maio/jun. 2007. Disponível em < https://www.embrapa.br/busca-de-publicacoes/-/publicacao/124697/substituicao-deculturas-uma-abordagem-empirica-envolvendo-cana-de-acucar-soja-carne-bovina-emilho> acesso em 03 jan. 2018.

SPAROVEK, G.; et al. A revisão do Código Florestal brasileiro. Novos Estudos, São Paulo, n. 89, p. 181-205, 2011.

VARJABEDIAN, R. Lei da Mata Atlântica: Retrocesso ambiental. Estud. av., São Paulo, v. 24, n. 68, p. 147-160, 2010. Disponível em:

$<$ http://www.scielo.br/scielo.php?script=sci_arttext\&pid=S0103-

$40142010000100013 \&$ lng=en\&nrm=iso $>$. acesso em 26 aug. 2016.

Vieira Filho, José Eustáquio. (2017). Expansão pecuária no Brasil e proposição metodológica de cálculo da produtividade em termos de sustentabilidade ambiental. ABDE 227-258. In Prêmio ABDE-BID / Associação Brasileira de Desenvolvimento. - Rio de Janeiro : ABDE Editorial, 2017.320p.

VIEIRA FILHO, J. E. R.; CAMPOS, A. C.; FERREIRA, C. M. C. Abordagem alternativa do crescimento agrícola: um modelo de dinâmica evolucionária. Revista brasileira de inovação, v. 4, n. 2, p. 425-476, jul./dez. 2005.

VIEIRA FILHO, J. E. R.; SILVEIRA, J. M. F. J. Competências organizacionais, trajetória tecnológica e aprendizado local na agricultura: o paradoxo de Prebisch. Revista Economia e Sociedade, v.25, n.3(58), p. 599-629, 2016.

Mudança tecnológica na agricultura: uma revisão crítica da literatura e o papel das economias de aprendizado. Revista de economia e sociologia rural, v. 50, n. 4, p. 717-738, out./dez. 2012.

VIEIRA FILHO, J.E.R.; Fishlow, A. Agricultura e indústria no Brasil: inovação e competitividade. Brasília :Ipea, 2017.305 p.

VIEIRA FILHO, José Eustáquio Ribeiro; FISHLOW, Albert. Agricultura e indústria no Brasil: inovação e competitividade. Brasília: Ipea, 2017.305 p. 


\section{APÊNDICES}

APÊNDICE A. Uso da terra e Déficit de reserva legal

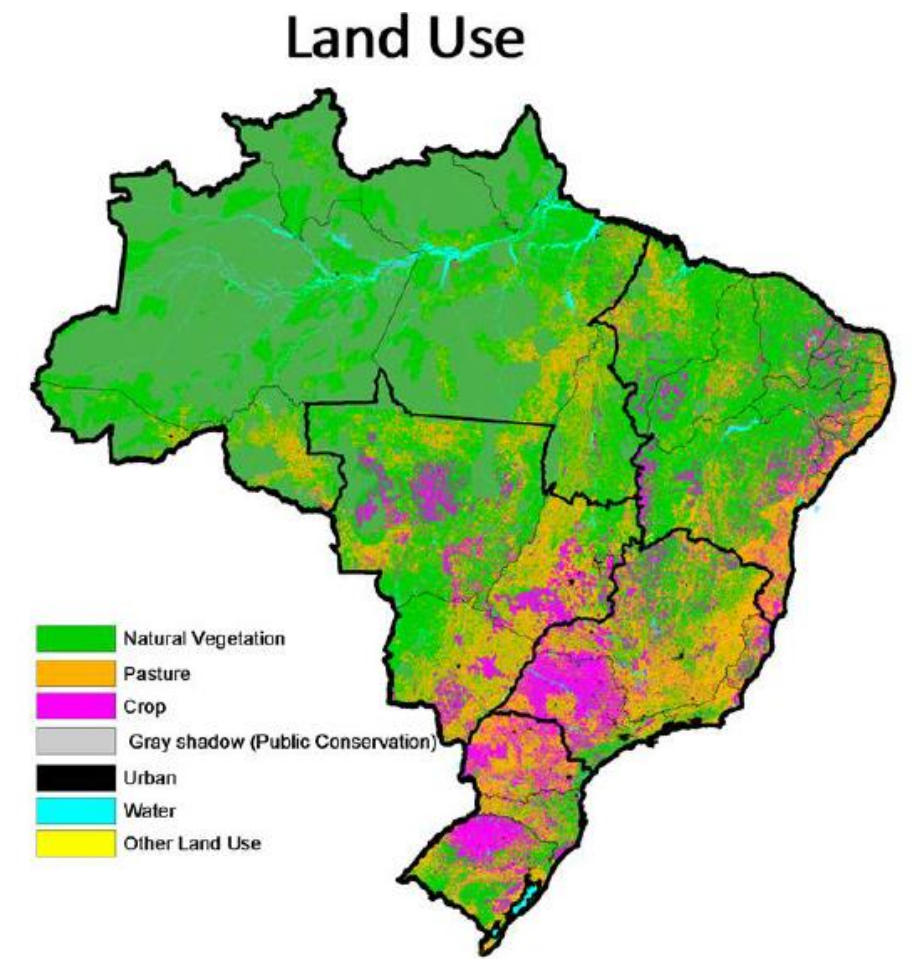

Legal Reserve (LR) deficit in relation to need

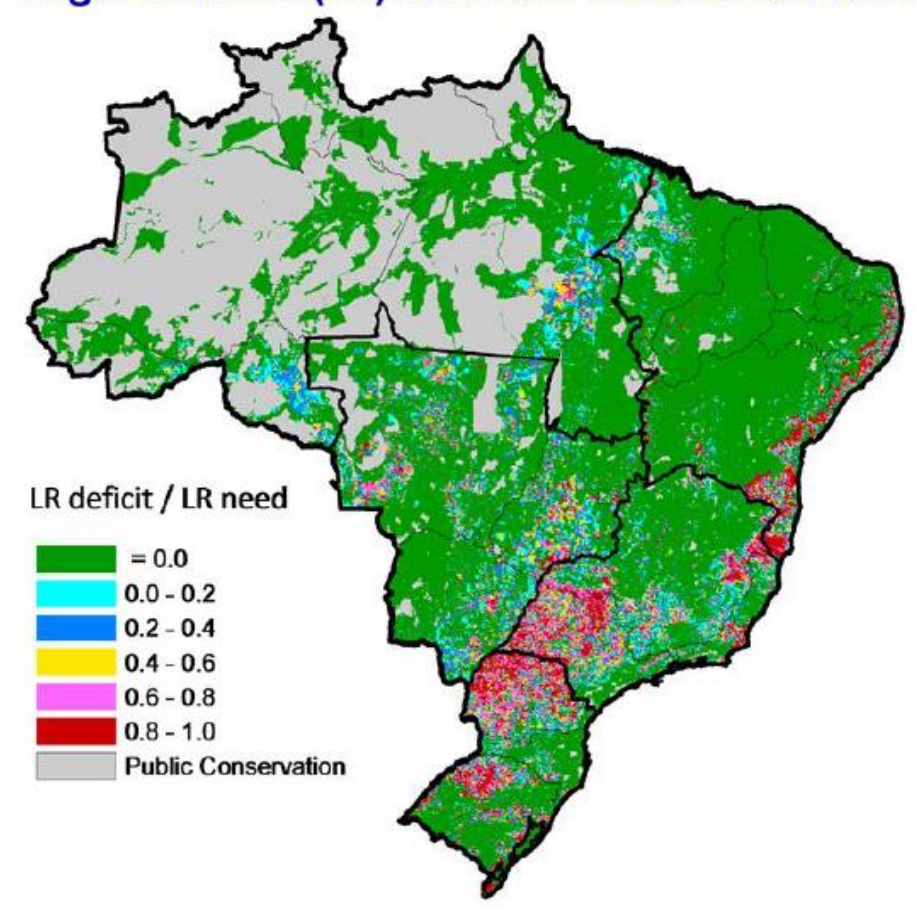

Fonte: adaptado de Sparovek et al. (2015) 
APÊNDICE B. Ao que se refere a Ação Direta de Inconstitucionalidade contra o Novo Código Florestal

\begin{tabular}{|c|c|}
\hline $\begin{array}{c}\text { AÇÃO DIRETA DE } \\
\text { INCONSTITUCIONALIDADE }\end{array}$ & PEDIDO \\
\hline 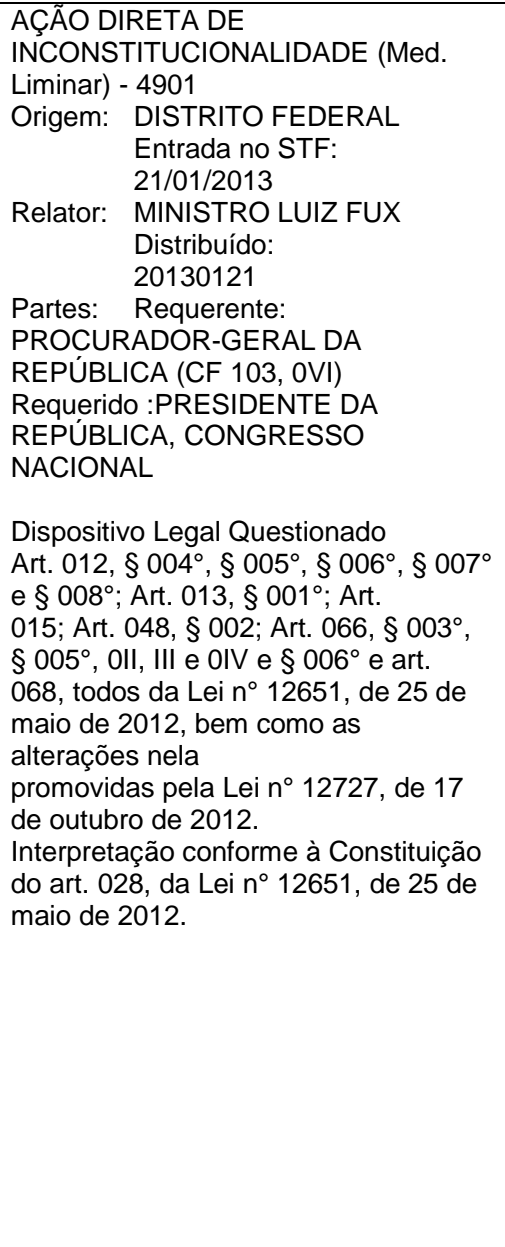 & $\begin{array}{l}\text { Declarar a inconstitucionalidade dos dispositivos, } \\
\text { pois estes preveem a diminuição das áreas de } \\
\text { RL, equiparando-as às UCs - cuja finalidade é } \\
\text { distinta da primeira. } \\
\text { Declarar a inconstitucionalidade dos dispositivos, } \\
\text { pois estes dispensam constituição de RL para } \\
\text { certas atividades, diminuindo o padrão de } \\
\text { proteção ambiental. } \\
\text { Declarar a inconstitucionalidade do dispositivo, } \\
\text { pois não há fundamento para instituir servidão } \\
\text { e cotas de reserva ambiental (CRAs) sobre } \\
\text { área mantida com vegetação de RL, o que, } \\
\text { consequentemente, diminuiria as áreas de RL. } \\
\text { Requer que a interpretação do dispositivo } \\
\text { abranja todas as formas de subutilização ou a } \\
\text { utilização da propriedade nos termos dos §§ 3o } \\
\text { 4o do art. 6o da Lei no } 8.629 / 1993 . \\
\text { Declarar a inconstitucionalidade do dispositivo, } \\
\text { pois este descaracteriza o regime de proteção } \\
\text { das RLs. } \\
\text { Declarar a inconstitucionalidade do dispositivo, } \\
\text { pois este descaracteriza o regime de proteção das } \\
\text { RLs visando à exploração econômica desta área } \\
\text { não à sua regeneração. } \\
\text { Requer: i) a inconstitucionalidade dos arts. 48, } \\
\text { § 2o, e } 66, \S 50, \text { II e III, pois estes acarretam a } \\
\text { diminuição das áreas protegidas e carecem de } \\
\text { propriedade técnica; e ii) interpretar a expressão } \\
\text { "localizada no mesmo bioma" (inciso IV do } \\
\text { §5o do art. 66) como exclusiva para áreas com } \\
\text { identidade ecológica. } \\
\text { Requer: i) a inconstitucionalidade do art. } 68, \\
\text { pois este prevê a consolidação das áreas que } \\
\text { foram desmatadas antes das modificações } \\
\text { das porcentagens de RL, excluindo-se da } \\
\text { proteção um número incalculável de áreas; ii) a } \\
\text { inconstitucionalidade da expressão "excetuados } \\
\text { os casos previstos no art. } 68 \text { desta lei", do art. } \\
\text { 12, caput. }\end{array}$ \\
\hline 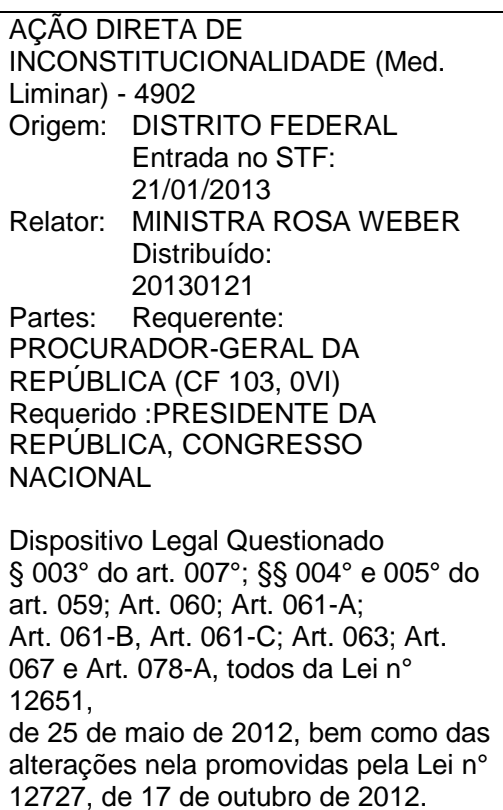 & $\begin{array}{l}\text { Declarar a inconstitucionalidade da expressão "realizada após } 22 \text { de julho de } 2008 \text { ", } \\
\text { pois está isenta os causadores de danos ambientais da obrigação de } \\
\text { repará-los. } \\
\text { Declarar a inconstitucionalidade da expressão “após } 22 \text { de julho de } 2008 \text { ", pois está } \\
\text { isenta os desmatamentos irregulares ocorridos antes deste período, permitindo a } \\
\text { geração de direitos pela prática de ilícitos. } \\
\text { Declarar a inconstitucionalidade dos dispositivos, uma vez que estes dão insegurança } \\
\text { jurídica e suspendem a atividade fiscalizatória e punitiva do Estado. Além disso, } \\
\text { inexistem elementos mínimos que assegurem a eficácia dos programas propostos. } \\
\text { Declarar a inconstitucionalidade dos dispositivos, por estabelecerem um sistema } \\
\text { técnico de recuperação de áreas. } \\
\text { Declarar a inconstitucionalidade do dispositivo, por estabelecer mais uma } \\
\text { possibilidade de consolidação de danos ambientais, bem como concede uma } \\
\text { desoneração do dever de restaurar as áreas de RL. } \\
\text { Declarar a inconstitucionalidade do dispositivo, porque este permite a concessão de } \\
\text { crédito agrícola independentemente da regularidade ambiental. }\end{array}$ \\
\hline 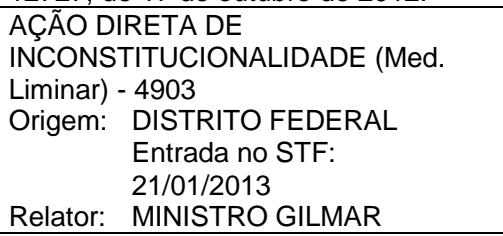 & $\begin{array}{l}\text { Em relação ao art. } 225 \text { da CF, §10, III: i) conferir interpretação no sentido de que } \\
\text { todas as hipóteses de intervenção excepcional em APP sejam condicionadas à } \\
\text { inexistência de alternativa técnica e/ou locacional, comprovada mediante processo } \\
\text { administrativo próprio; e ii) declarar inconstitucionais as expressões "gestão de } \\
\text { resíduos" e "instalações necessárias à realização de competições esportivas } \\
\text { estaduais, nacionais ou internacionais" (art. 3o, VIII, b). } \\
\text { Possui caráter menos restritivo que a Resolução Conama no 425/2010 - o art. 4o }\end{array}$ \\
\hline
\end{tabular}




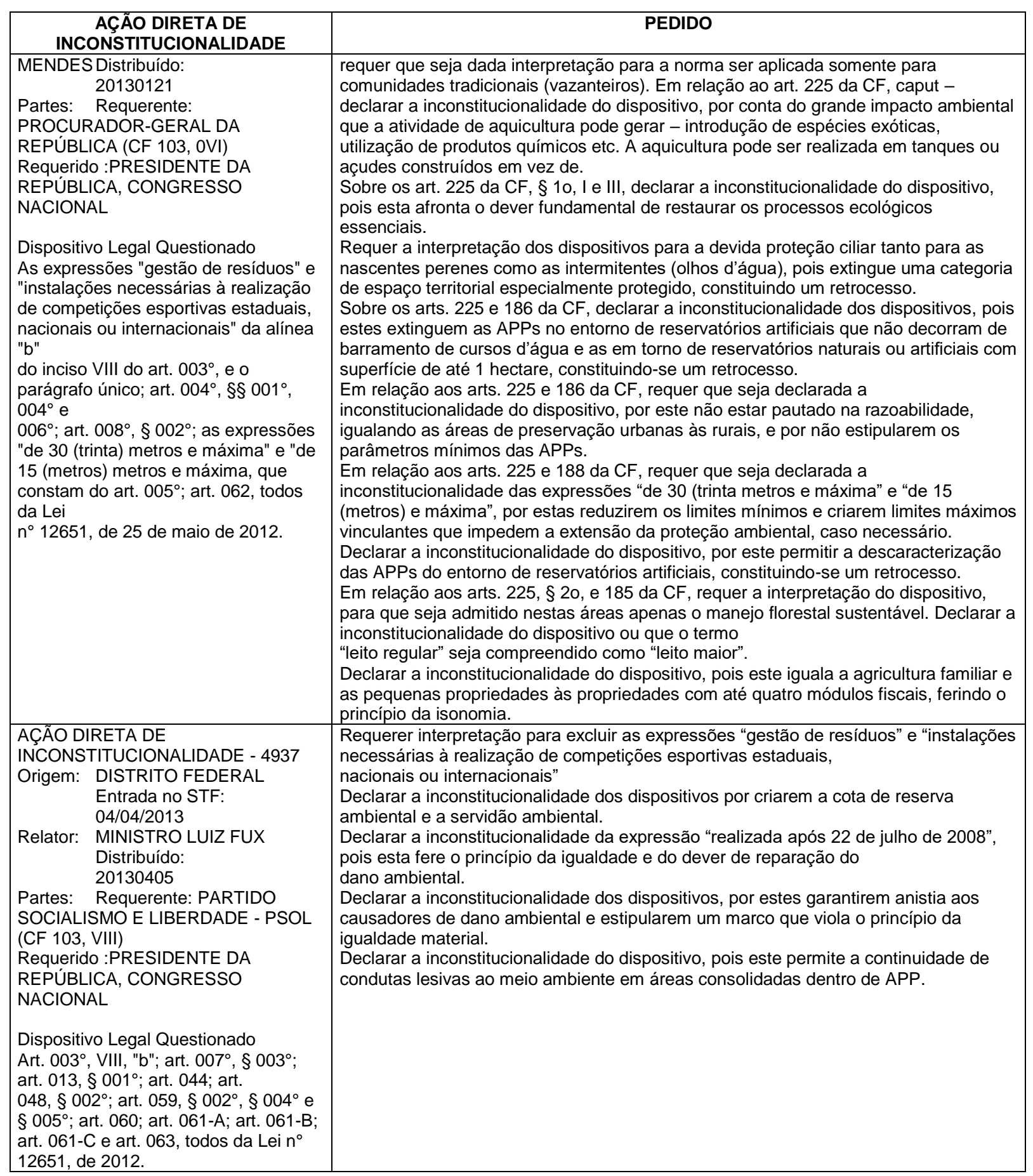

Fonte: adaptado de Machado (2016). 
APÊNDICE C. Correspondência entre classes de cobertura terrestre GLOBIOM e IBGE classes de cobertura terrestre

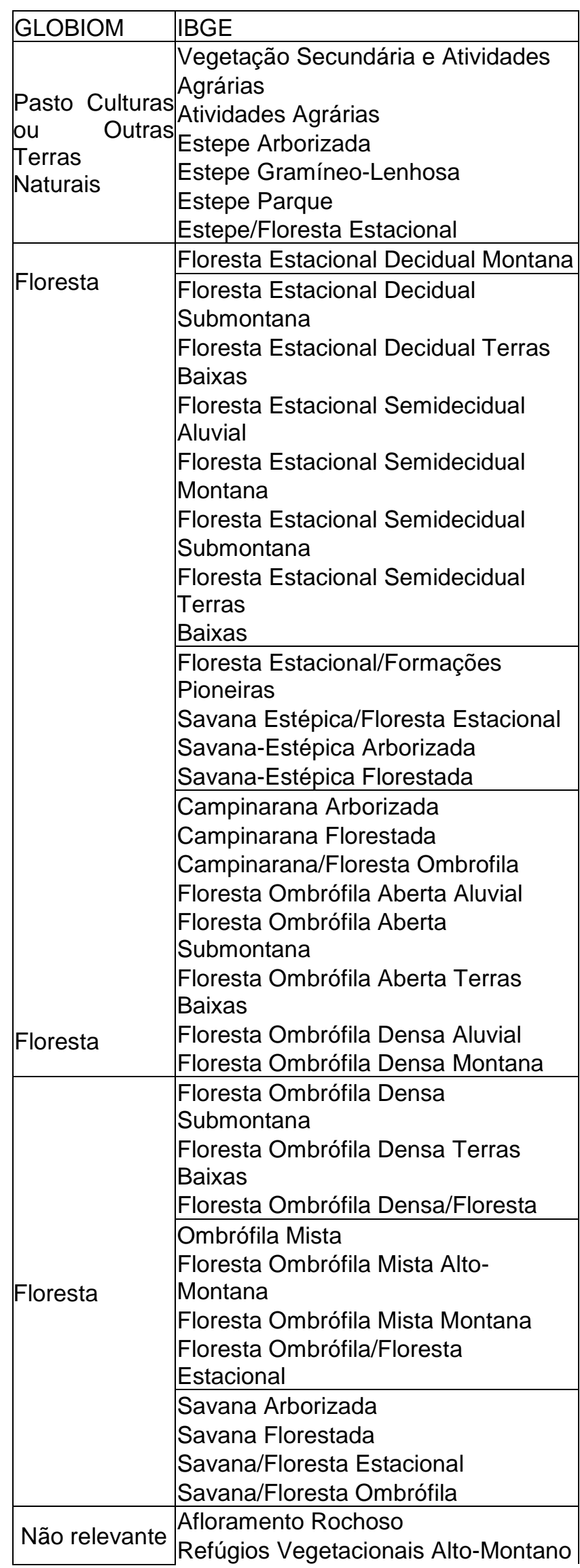




\begin{tabular}{|c|c|}
\hline GLOBIOM & IBGE \\
\hline & $\begin{array}{l}\text { Refúgios Vegetacionais Montano } \\
\text { Coastal water mass } \\
\text { Continental water mass }\end{array}$ \\
\hline & $\begin{array}{l}\text { Campinarana Arbustiva } \\
\text { Campinarana Gramíneo-Lenhosa } \\
\text { Savana-Estépica Gramíneo-Lenhosa } \\
\text { Savana-Estépica Parque } \\
\end{array}$ \\
\hline $\begin{array}{c}\text { Outras terras } \\
\text { naturais }\end{array}$ & $\begin{array}{l}\text { Savana Gramíneo-Lenhosa } \\
\text { Savana Parque } \\
\text { Savana/Formações Pioneiras } \\
\text { Savana/Savana Estépica } \\
\text { Savana/Savana Estépica/Floresta } \\
\text { Estacional }\end{array}$ \\
\hline Pantanal & $\begin{array}{l}\text { Vegetação com Influência Fluvial } \\
\text { Lacustre } \\
\text { Vegetação com Influência } \\
\text { Fluvio-marinha } \\
\text { Áreas das Formações Pioneiras } \\
\text { Vegetação com Influência Marinha }\end{array}$ \\
\hline
\end{tabular}

Fonte: adaptado de REDD-PAC (2015) 
APÊNDICE D. Desvio percentual da produção total das indústrias (produtos selecionados), por cenário e por grande região, Brasil, no acumulado do período 2010-2030 (AGGxtot(D)).

\begin{tabular}{|c|c|c|c|c|c|c|c|c|c|c|c|c|c|c|c|c|c|c|}
\hline \multirow{2}{*}{$\begin{array}{l}\text { Indústria } \\
\text { cenário }\end{array}$} & \multicolumn{3}{|c|}{ Norte } & \multicolumn{3}{|c|}{ Nordeste } & \multicolumn{3}{|c|}{ SP } & \multicolumn{3}{|c|}{$\begin{array}{l}\text { Restante do } \\
\text { Sudeste }\end{array}$} & \multicolumn{3}{|c|}{ Sul } & \multicolumn{3}{|c|}{ Centro-Oeste } \\
\hline & 1 & 2 & 3 & 1 & 2 & 3 & 1 & 2 & 3 & 1 & 2 & 3 & 1 & 2 & 3 & 1 & 2 & 3 \\
\hline 1 Arroz em casca & $-8,51$ & $-4,67$ & 62,12 & 1,87 & $-7,33$ & 3,48 & 0,31 & $-1,21$ & 0,05 & 0,79 & 5,88 & 5,75 & $-0,14$ & 1,53 & $-12,08$ & $-0,22$ & 1,77 & 3,17 \\
\hline 2 Milho em grão & $-0,48$ & $-0,37$ & 0,18 & 0,05 & 1,04 & 0,31 & $-1,55$ & 4,61 & 4,65 & 0,8 & $-0,32$ & 1,33 & $-1,13$ & $-0,77$ & $-10,95$ & 0,28 & $-2,37$ & $-0,32$ \\
\hline 3 Trigo e outros cereais & $-0,33$ & 0,44 & $-0,14$ & $-0,12$ & 0,26 & 0 & 8,39 & 0,71 & $-14,26$ & 0,2 & $-0,54$ & $-0,44$ & $-0,08$ & $-0,89$ & $-0,85$ & $-1,89$ & $-1,12$ & 5,05 \\
\hline 4 Cana-de-açúcar & $-19,16$ & 2,81 & 7,28 & $-0,97$ & 0,35 & $-1,08$ & 0,78 & $-1,07$ & $-3,74$ & $-0,77$ & 0,3 & 1,73 & $-1,38$ & $-0,27$ & 10,77 & $-0,56$ & 2,82 & 3,12 \\
\hline 5 Soja em grão & 1,17 & 2,41 & 2,92 & 3,19 & 4,5 & 3,04 & 2,53 & 6,83 & $-2,62$ & 7,04 & 12,72 & $-0,14$ & 1,08 & 7,45 & 5,13 & $-9,21$ & $-13,86$ & $-10,31$ \\
\hline $\begin{array}{l}6 \text { Outros produtos e } \\
\text { serviços da lavoura }\end{array}$ & 10,84 & 6,94 & 3,58 & $-2,35$ & $-1,73$ & $-0,87$ & $-0,14$ & $-0,21$ & $-0,77$ & 0,23 & 0,03 & $-0,74$ & $-0,09$ & $-0,03$ & $-0,75$ & $-0,04$ & 0,06 & $-0,52$ \\
\hline 7 Mandioca & $-16,93$ & $-9,94$ & $-4,73$ & 1,6 & 5,14 & $-2,45$ & 56,5 & $-9,17$ & 48,35 & 5,17 & 5,49 & $-7,96$ & 8,75 & $-15,66$ & 5,61 & $-23,05$ & 3,75 & 6,64 \\
\hline 8 Fumo em folha & 7,96 & 22,63 & $-6,65$ & $-3,06$ & $-3,05$ & $-1,09$ & $-0,32$ & $-0,25$ & 0,98 & 0,2 & $-0,15$ & 0,64 & 0,05 & 0,28 & 1,51 & $-0,01$ & 0,53 & 1,14 \\
\hline 9 Algodão herbáceo & 0 & $-0,36$ & $-0,08$ & 0,61 & $-1,17$ & $-1,56$ & $-0,07$ & $-0,19$ & 0,06 & $-3,46$ & $-0,53$ & $-3,03$ & $-0,08$ & $-2,86$ & $-2,56$ & 0,15 & 0,53 & 0,03 \\
\hline 10 Frutas cítricas & 1,51 & 2,24 & $-1,18$ & $-5,13$ & $-2,24$ & $-0,85$ & 0,11 & $-0,27$ & $-0,73$ & 0,8 & 0,02 & $-0,65$ & 0,49 & 0,17 & $-0,43$ & 0,36 & 0,54 & $-0,33$ \\
\hline 11 Café em grão & 45,54 & 22,91 & 19,8 & $-1,63$ & $-2,11$ & $-0,74$ & $-0,31$ & $-0,27$ & $-0,47$ & $-0,61$ & $-0,46$ & $-0,64$ & $-0,39$ & $-0,28$ & $-0,52$ & $-0,82$ & 0,33 & $-1,03$ \\
\hline $\begin{array}{l}12 \text { Exploração florestal } \\
\text { e silvicultura }\end{array}$ & $-12,06$ & 11,64 & 14,15 & $-5,8$ & 7,45 & 5,03 & 1,95 & 0,45 & $-1,9$ & 1,47 & $-1,76$ & $-4,5$ & 0,02 & $-0,45$ & $-2,16$ & 2,91 & $-13,49$ & $-4,73$ \\
\hline 13 Bovinos e outros animais & $-5,26$ & $-1,17$ & $-1,2$ & 0,48 & 1,9 & 2,87 & 2,41 & $-0,46$ & $-2,63$ & 2,4 & 1,89 & $-5,58$ & 2,49 & $-8,43$ & $-14,58$ & $-1,95$ & $-5,82$ & $-16,89$ \\
\hline 14 Leite & $-4,85$ & 0,03 & $-0,66$ & $-0,23$ & 1,05 & 3,03 & 1 & $-1,18$ & $-2,33$ & 1,31 & 1,53 & $-4,69$ & 1,49 & $-8,74$ & $-13,82$ & 4,68 & $-4,57$ & $-37,37$ \\
\hline $\begin{array}{l}15 \text { Suínos, aves, } \\
\text { ovos e produtos da pesca }\end{array}$ & 1,06 & $-0,04$ & $-1,71$ & $-0,3$ & $-0,66$ & $-0,84$ & $-0,6$ & $-0,38$ & $-1,28$ & $-0,25$ & $-0,04$ & $-0,8$ & $-0,33$ & $-0,57$ & $-1,69$ & $-0,08$ & $-0,02$ & $-2,55$ \\
\hline 16 Mineração & 0,02 & $-0,32$ & $-0,22$ & 0,13 & 0 & $-0,04$ & $-0,04$ & 0,06 & 0,01 & $-0,02$ & 0,01 & 0,04 & $-0,04$ & 0,1 & 0,05 & 0,42 & 0,56 & 2,24 \\
\hline 17 Carnes & 0,14 & $-0,21$ & 0,32 & $-0,45$ & $-0,07$ & 1,5 & $-0,3$ & $-0,77$ & $-2,58$ & $-0,02$ & $-0,19$ & $-1,71$ & $-0,22$ & $-1,42$ & $-3,48$ & $-0,56$ & $-0,26$ & $-5,4$ \\
\hline
\end{tabular}




\begin{tabular}{|c|c|c|c|c|c|c|c|c|c|c|c|c|c|c|c|c|c|c|}
\hline \multirow{2}{*}{$\begin{array}{l}\text { Indústria } \\
18 \text { Óleos }\end{array}$} & \multicolumn{3}{|c|}{ Norte } & \multicolumn{3}{|c|}{ Nordeste } & \multicolumn{3}{|c|}{ SP } & \multicolumn{3}{|c|}{$\begin{array}{l}\text { Restante do } \\
\text { Sudeste }\end{array}$} & \multicolumn{3}{|c|}{ Sul } & \multicolumn{3}{|c|}{ Centro-Oeste } \\
\hline & 0,37 & 0,93 & $-0,91$ & $-0,37$ & 0,08 & 0,68 & $-0,47$ & $-0,97$ & $-3,06$ & 0,36 & 0,32 & $-2,68$ & $-0,3$ & $-2,17$ & $-5,01$ & $-1,08$ & $-1,64$ & $-6,45$ \\
\hline 19 Laticínios & 0,45 & 0,02 & 0,16 & $-0,52$ & $-0,29$ & 1,24 & $-0,3$ & $-0,77$ & $-2,15$ & 0,02 & $-0,26$ & $-1,77$ & $-0,13$ & $-1,19$ & $-2,77$ & $-0,39$ & $-0,23$ & $-5,51$ \\
\hline 20 Arroz beneficiado & 0,48 & $-0,07$ & 0,9 & $-0,19$ & 0,28 & 2,04 & $-0,21$ & $-0,31$ & $-0,79$ & 0,09 & 0,26 & $-0,36$ & $-0,1$ & $-0,91$ & $-1,55$ & $-0,29$ & 0,14 & $-2,77$ \\
\hline 21 Refino de açúcar & 4,05 & 3,48 & $-0,5$ & $-0,95$ & $-2,14$ & $-5,27$ & $-0,57$ & $-1,96$ & $-6,65$ & 0,15 & $-0,16$ & $-2,96$ & 0,03 & $-2,67$ & $-6,81$ & $-0,5$ & $-0,67$ & $-7,13$ \\
\hline 22 Café processado & 0,25 & $-0,32$ & 0,34 & $-0,28$ & $-0,12$ & 1,63 & $-0,56$ & $-1,75$ & $-5,49$ & 0,04 & $-0,22$ & $-1,64$ & $-0,13$ & $-1,47$ & $-3,43$ & $-0,39$ & $-0,29$ & $-5,89$ \\
\hline $\begin{array}{l}23 \text { Outros produtos } \\
\text { alimentícios }\end{array}$ & 0,19 & $-0,28$ & $-0,52$ & $-0,53$ & $-0,47$ & 0,16 & $-0,3$ & $-0,8$ & $-2,59$ & 0,02 & $-0,18$ & $-1,48$ & $-0,03$ & $-0,4$ & $-0,24$ & $-0,49$ & $-0,58$ & $-5,99$ \\
\hline $\begin{array}{l}24 \text { Têxteis, vestuário e } \\
\text { calçados }\end{array}$ & 0,78 & $-0,24$ & $-1,66$ & 0,36 & $-0,09$ & $-0,46$ & 0,1 & 0,17 & 0,32 & 0 & 0,05 & 0,32 & 0,08 & 0,07 & 0,12 & 0,32 & 0,53 & 1,14 \\
\hline $\begin{array}{l}25 \text { Celulose, papel } \\
\text { e gráfica }\end{array}$ & $-0,08$ & $-1,57$ & $-1,1$ & $-0,89$ & 0,98 & 0,72 & $-0,34$ & 0,2 & 0,01 & $-0,13$ & $-0,02$ & $-0,18$ & $-0,78$ & 0,5 & 0,1 & 1,04 & 0,23 & 1,71 \\
\hline 26 Gasolina & $-0,11$ & 0,12 & $-0,26$ & $-0,17$ & $-0,07$ & $-0,12$ & $-0,05$ & $-0,08$ & $-0,22$ & $-0,1$ & $-0,07$ & $-0,26$ & $-0,08$ & $-0,05$ & $-0,17$ & $-0,25$ & $-0,29$ & 0,06 \\
\hline 27 Gasoalcool & 0,12 & 0,18 & $-0,4$ & $-0,28$ & $-0,08$ & $-0,24$ & $-0,01$ & $-0,07$ & $-0,23$ & $-0,03$ & $-0,05$ & $-0,38$ & $-0,03$ & $-0,07$ & $-0,23$ & $-0,32$ & $-0,65$ & $-0,58$ \\
\hline 28 Álcool & 0,99 & $-0,1$ & -1 & $-0,09$ & $-0,12$ & $-0,16$ & 0,15 & $-0,48$ & $-1,2$ & $-0,24$ & $-0,28$ & $-0,11$ & $-0,15$ & $-0,54$ & 0,02 & 0,09 & 1,76 & 0,72 \\
\hline $\begin{array}{l}29 \text { Óleo combustível } \\
\text { e gás }\end{array}$ & $-0,03$ & 0,34 & 0,04 & $-0,27$ & $-0,05$ & 0,03 & 0 & 0 & $-0,02$ & $-0,04$ & $-0,02$ & $-0,15$ & $-0,08$ & $-0,03$ & $-0,09$ & $-0,47$ & $-0,22$ & $-0,3$ \\
\hline 30 Óleo Diesel & $-0,26$ & 0,1 & $-0,07$ & $-0,16$ & 0 & 0,08 & $-0,11$ & $-0,1$ & $-0,24$ & $-0,16$ & $-0,06$ & $-0,23$ & $-0,07$ & $-0,07$ & $-0,23$ & $-0,51$ & $-0,94$ & $-0,23$ \\
\hline 31 Petroquímicos & $-0,43$ & 0,02 & $-0,07$ & $-0,02$ & $-0,1$ & $-0,15$ & $-0,03$ & $-0,1$ & $-0,28$ & $-0,08$ & $-0,14$ & $-0,25$ & $-0,16$ & 0,06 & 0 & 0,02 & 0,11 & 1,19 \\
\hline 32 Out Manufaturados & $-1,66$ & 0,89 & 0,66 & $-0,12$ & $-0,35$ & $-0,47$ & $-0,07$ & $-0,17$ & $-0,53$ & $-0,12$ & $-0,22$ & $-0,5$ & $-0,41$ & 0,12 & $-0,2$ & $-0,32$ & 0,32 & 0,06 \\
\hline $\begin{array}{l}33 \text { Automóveis, Caminhões } \\
\text { e Ônibus }\end{array}$ & $-0,07$ & $-0,1$ & 1,7 & 0,63 & 0,58 & 1,75 & 0,41 & 0,55 & 1,78 & 0,31 & 0,39 & 1,7 & 0,46 & 0,59 & 1,95 & 0,6 & 0,38 & 2,83 \\
\hline 34 Metalúrgicos & 0,15 & $-0,38$ & $-0,04$ & 0,33 & 0,15 & 0,19 & 0,06 & 0,14 & 0,36 & $-0,02$ & 0,01 & 0,32 & 0,03 & 0,22 & 0,54 & 0,43 & 0,52 & 2,18 \\
\hline 35 SIUP & $-0,05$ & $-0,1$ & $-0,27$ & 0,05 & 0,02 & $-0,06$ & $-0,06$ & $-0,04$ & $-0,11$ & $-0,07$ & $-0,06$ & $-0,12$ & $-0,08$ & $-0,06$ & $-0,15$ & 0,06 & 0,06 & $-0,26$ \\
\hline 36 Comercio & $-0,5$ & 0,05 & 0,67 & $-0,17$ & $-0,04$ & $-0,01$ & 0,03 & 0,01 & $-0,04$ & 0,05 & 0,02 & $-0,16$ & $-0,02$ & 0,06 & $-0,03$ & $-0,82$ & $-1,15$ & $-2,57$ \\
\hline
\end{tabular}




\begin{tabular}{|c|c|c|c|c|c|c|c|c|c|c|c|c|c|c|c|c|c|c|}
\hline $\begin{array}{l}\text { Indústria } \\
37 \text { Transporte }\end{array}$ & \multicolumn{3}{|c|}{ Norte } & \multicolumn{3}{|c|}{ Nordeste } & \multicolumn{3}{|c|}{$\mathrm{SP}$} & \multicolumn{3}{|c|}{$\begin{array}{l}\text { Restante do } \\
\text { Sudeste }\end{array}$} & \multicolumn{3}{|c|}{ Sul } & \multicolumn{3}{|c|}{ Centro-Oeste } \\
\hline 38 Serviços & 0,26 & $-0,13$ & $-0,93$ & $-0,26$ & $-0,18$ & $-0,53$ & $-0,13$ & $-0,15$ & $-0,49$ & $-0,1$ & $-0,14$ & $-0,5$ & $-0,11$ & $-0,17$ & $-0,53$ & 0,07 & 0,01 & $-0,22$ \\
\hline
\end{tabular}

Fonte: Elaboração própria. 
APÊNDICE E. Variação do rendimento da terra, em cada cenário, por produto da agropecuária, em cada região, Brasil, 2010-2030

\begin{tabular}{|c|c|c|c|c|c|}
\hline Cenário & Produto & Região & $\begin{array}{c}\text { Maior } \\
\text { rendimento por } \\
\text { cenário }\end{array}$ & Região & $\begin{array}{c}\text { Menor } \\
\text { rendimento } \\
\text { por cenário }\end{array}$ \\
\hline 1 & 1 Arroz em casca & $\begin{array}{l}\text { Pará- } \\
\text { Tocantins }\end{array}$ & 3,13 & $\begin{array}{l}\text { Rondônia } \\
\text { Parte do }\end{array}$ & $-2,94$ \\
\hline 2 & 1 Arroz em casca & $\begin{array}{l}\text { Bahia } \\
\text { Santa } \\
\text { Catarina- } \\
\text { Rio Grande }\end{array}$ & 2,66 & $\begin{array}{l}\text { Norte } \\
\text { Rio de } \\
\text { Janeiro - } \\
\text { Espírito }\end{array}$ & $-5,72$ \\
\hline 3 & 1 Arroz em casca & $\begin{array}{l}\text { do Sul } \\
\text { Parte do }\end{array}$ & 3,53 & $\begin{array}{l}\text { Santo } \\
\text { Pará- }\end{array}$ & $-14,87$ \\
\hline 1 & 2 Milho em grão & Norte & 4,31 & $\begin{array}{l}\text { Tocantins } \\
\text { Parte do }\end{array}$ & $-3,67$ \\
\hline 2 & 2 Milho em grão & $\begin{array}{l}\text { Goiás e DF } \\
\text { Santa } \\
\text { Catarina- } \\
\text { Rio Grande }\end{array}$ & 5,37 & Nordeste & $-5,77$ \\
\hline 3 & $\begin{array}{l}2 \text { Milho em grão } \\
3 \text { Trigo e outros }\end{array}$ & $\begin{array}{l}\text { do Sul } \\
\text { Pará- }\end{array}$ & 5,13 & Goiás e DF & $-4,89$ \\
\hline 1 & $\begin{array}{l}\text { cereais } \\
3 \text { Trigo e outros }\end{array}$ & $\begin{array}{l}\text { Tocantins } \\
\text { Mato }\end{array}$ & 0,08 & $\begin{array}{l}\text { Goiás e DF } \\
\text { Parte do }\end{array}$ & $-0,45$ \\
\hline 2 & $\begin{array}{l}\text { cereais } \\
3 \text { Trigo e outros }\end{array}$ & Grosso & 1,01 & $\begin{array}{l}\text { Nordeste } \\
\text { Mato }\end{array}$ & 0,09 \\
\hline 3 & cereais & $\begin{array}{l}\text { Goiás e DF } \\
\text { Pará- }\end{array}$ & 0,36 & $\begin{array}{l}\text { Grosso } \\
\text { Parte do }\end{array}$ & $-0,25$ \\
\hline 1 & 4 Cana-de-açúcar & $\begin{array}{l}\text { Tocantins } \\
\text { Mato } \\
\text { Grosso do }\end{array}$ & 85,42 & $\begin{array}{l}\text { Norte } \\
\text { Parte do }\end{array}$ & $-47,9$ \\
\hline 2 & 4 Cana-de-açúcar & $\begin{array}{l}\text { Sul } \\
\text { Mato }\end{array}$ & 35,27 & Norte & $-72,14$ \\
\hline 3 & 4 Cana-de-açúcar & $\begin{array}{l}\text { Grosso do } \\
\text { Sul } \\
\text { Pará- }\end{array}$ & 13,01 & $\begin{array}{l}\text { Pará- } \\
\text { Tocantins } \\
\text { Minas }\end{array}$ & $-65,63$ \\
\hline 1 & 5 Soja em grão & $\begin{array}{l}\text { Tocantins } \\
\text { Pará- }\end{array}$ & 58,16 & $\begin{array}{l}\text { Gerais } \\
\text { Minas }\end{array}$ & $-7,69$ \\
\hline 2 & 5 Soja em grão & Tocantins & 36,74 & $\begin{array}{l}\text { Gerais } \\
\text { Santa } \\
\text { Catarina- } \\
\text { Rio Grande }\end{array}$ & $-22,07$ \\
\hline 3 & $\begin{array}{l}5 \text { Soja em grão } \\
6 \text { Outros produtos e }\end{array}$ & $\begin{array}{l}\text { Goiás e DF } \\
\text { Parte do }\end{array}$ & 25,73 & do Sul & $-17,85$ \\
\hline 1 & $\begin{array}{l}\text { serviços da lavoura } \\
6 \text { Outros produtos e }\end{array}$ & $\begin{array}{l}\text { Nordeste } \\
\text { Maranhão- }\end{array}$ & 2,91 & $\begin{array}{l}\text { Rondônia } \\
\text { Parte do }\end{array}$ & $-5,08$ \\
\hline 2 & $\begin{array}{l}\text { serviços da lavoura } \\
6 \text { Outros produtos e }\end{array}$ & $\begin{array}{l}\text { Piauí } \\
\text { Parte do }\end{array}$ & 1,02 & Norte & $-3,08$ \\
\hline 3 & serviços da lavoura & $\begin{array}{l}\text { Norte } \\
\text { Mato }\end{array}$ & 0,73 & Rondônia & $-1,9$ \\
\hline 1 & 7 Mandioca & Grosso & 20,2 & $\begin{array}{l}\text { São Paulo } \\
\text { Mato }\end{array}$ & $-10,35$ \\
\hline 2 & 7 Mandioca & $\begin{array}{l}\text { Pará- } \\
\text { Tocantins } \\
\text { Rio de } \\
\text { Janeiro - } \\
\text { Espírito }\end{array}$ & 12,83 & $\begin{array}{l}\text { Grosso do } \\
\text { Sul }\end{array}$ & 0,31 \\
\hline 3 & 7 Mandioca & $\begin{array}{l}\text { Santo } \\
\text { Mato }\end{array}$ & 5,65 & São Paulo & $-15,76$ \\
\hline 1 & 8 Fumo em folha & $\begin{array}{l}\text { Grosso } \\
\text { Mato }\end{array}$ & 1,76 & $\begin{array}{l}\text { Rondônia } \\
\text { Parte do }\end{array}$ & $-7,57$ \\
\hline 2 & 8 Fumo em folha & Grosso & 1,19 & Norte & $-3,75$ \\
\hline 3 & 8 Fumo em folha & $\begin{array}{l}\text { Goiás e DF } \\
\text { Minas }\end{array}$ & 1,54 & $\begin{array}{l}\text { Rondônia } \\
\text { Maranhão- }\end{array}$ & $-2,69$ \\
\hline 1 & 9 Algodão herbáceo & $\begin{array}{l}\text { Gerais } \\
\text { Parte do }\end{array}$ & 0,68 & $\begin{array}{l}\text { Piauí } \\
\text { Maranhão- }\end{array}$ & $-5,14$ \\
\hline 2 & 9 Algodão herbáceo & Nordeste & 2,91 & Piauí & $-4,74$ \\
\hline
\end{tabular}




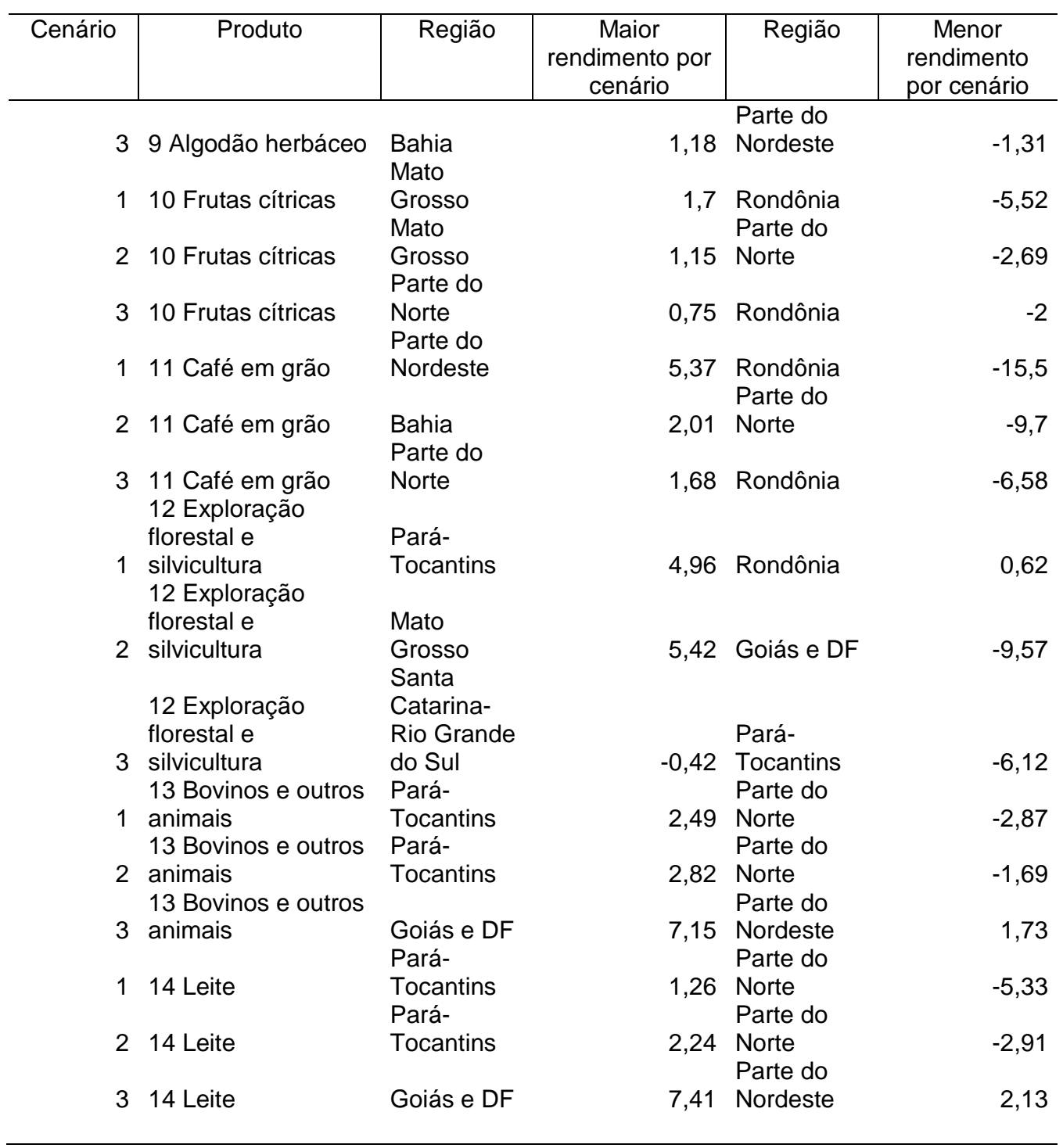

Fonte: Elaboração própria. 
APÊNDICE F. Mapa da distribuição, por quantil, do PIB per capta por UF, Brasil, 2013.

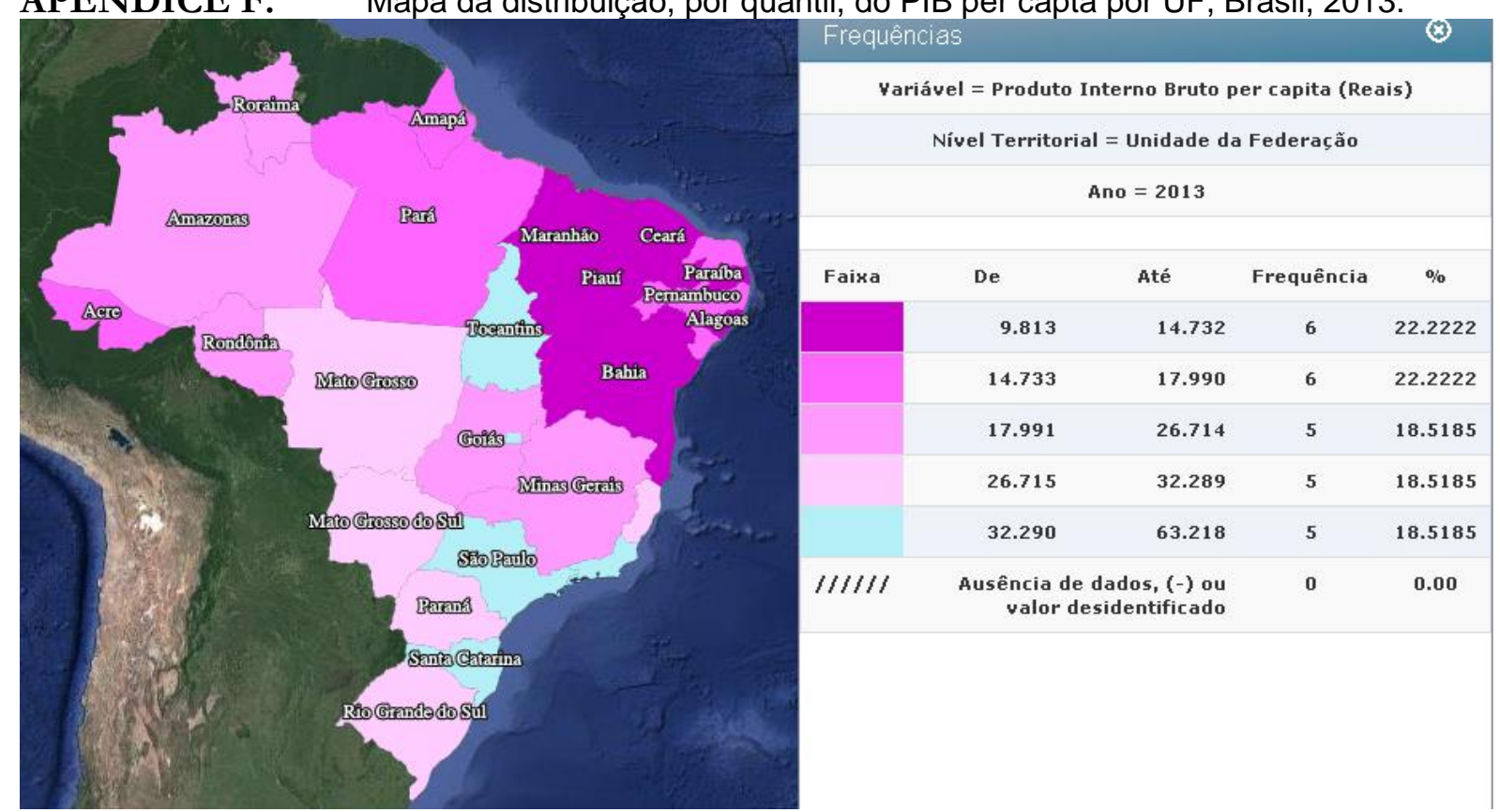

Fonte: IBGE, 2018. 